Southern Methodist University

SMU Scholar

\title{
Should We Defuse the 'Tax Bomb' Facing Lawyers Who Are Enrolled in Income-Based Student Loan Repayment Plans?
}

Gregory S. Crespi

Southern Methodist University, Dedman School of Law

\section{Recommended Citation}

Gregory Crespi, Should We Defuse the Tax Bomb Facing Lawyers Who Are Enrolled in Income-Based Student Loan Repayment Plans, 68 S.C. L. REV. 117 (2016).

This document is brought to you for free and open access by the Faculty Scholarship at SMU Scholar. It has been accepted for inclusion in Faculty Journal Articles and Book Chapters by an authorized administrator of SMU Scholar. For more information, please visit http://digitalrepository.smu.edu. 


\title{
ShOuld We Defuse The "TAX Bomb" FaCing LaWyers Who ARe EnRolled In InCome-Based Student LoAn RePayment Plans?
}

\author{
Gregory Crespi ${ }^{*}$
}

\begin{abstract}
Each year starting in about 2033, thousands and later tens of thousands of lawyers who incurred large student loan debts and were able to earn only relatively modest annual incomes in the twenty or twenty-five years following law school graduation will be subject to cancellation of indebtedness-based federal and sometimes also state income tax obligations. These obligations will result because a large portion of the substantial student loan debts that have been and will have been incurred by many law students will eventually be forgiven under one or another variant of the increasingly popular federal Income-Based Repayment Plan(s). Under these plans, forgiven debts will then be treated under the Internal Revenue Code and many state tax codes as taxable income.

These tax bills will often be in the neighborhood of $\$ 50,000$ to $\$ 100,000$ or even larger for those lawyers that have enrolled in the Pay As You Earn version of the Income-Based Repayment Plan, and approximately $\$ 15,000$ to $\$ 25,000$ for those lawyers who have enrolled in the earlier-established version of the Income-Based Repayment Plan. Many of these lawyers will have failed to adequately provide for this large tax obligation and will find that it will impair or even devastate their retirement plans.

The phrase "tax bomb" is an apt one to describe this sudden large tax obligation that will be imposed on income that is attributed to but not actually received by a relatively small group of taxpayers. This Article explains how this tax bomb was created and how the various statutes and regulations that define its scope and size have evolved over time from the original 2009 implementation of the Income-Based Repayment Plan through the Department of Education 2016 Revised Pay as You Earn Plan rules. It then offers detailed illustrative calculations regarding its magnitude for both Pay As You Earn Plan and Income-Based Repayment Plan law school graduate enrollees, both for typical individual enrollees and in the aggregate.

Based on available Department of Education statistics, I estimate that the number of law graduates who have enrolled in one or another of these

* Professor of Law, Dedman School of Law, Southern Methodist University. JD, Yale Law School, Ph.D., University of Iowa, M.S., George Washington University. I would like to thank Heather Jarvis, Deborah Merritt, John Brooks, Paul Campos, Phil Schrag, and Brian Tamanaha for their insightful comments on earlier drafts of the article, and Ma Ananda for her excellent research assistance.
\end{abstract}


federal Plans in 2015 or 2016, or who will enroll in later years, will be approximately equal in size to $50 \%$ of that year's law school graduating class. Under the further assumption that law Plan enrollees will experience average annual growth in their "real" incomes in the decades after their Plan enrollment of $2 \%$ per year, I estimate that the aggregate impact of the tax bomb on lawyers alone will start at only about $\$ 115$ million in 2033 , as it first impacts only about 1,650 lawyers. But by 2037 the impact will grow rapidly to over $\$ 700$ million per year as it begins to affect tens of thousands of lawyers annually. The size of the aggregate tax burden imposed on law school graduates alone will level off at about $\$ 1.2$ billion per year indefinitely by 2040 . Its impact will be even larger than this, perhaps significantly so, if one also considers the comparable and generally much smaller individual tax obligations that will be imposed on some medical school graduates Plan enrollees, other graduate and professional school Plan enrollees, and Plan enrollees who have borrowed only smaller sums for their undergraduate studies.

Finally, this Article discusses whether measures should be taken to mitigate or even eliminate this tax bomb before these obligations begin coming due in 2033. I consider a broad range of alternative legislative or regulatory measures that could accomplish this, including amendment of the Internal Revenue Code to abolish these consequences altogether. I have, however, concluded that no such measures are justified except for a minor amendment to the Internal Revenue Code allowing persons to pay their tax liabilities on forgiven student loan debt under one or another of these Plans over a period of several years.

ABSTRACT

I. INTRODUCTION

II. EVOlution OF THE INCOME-BASED REPAYMENT PLANS FROM THE "OLD" IBR PLAN THROUGH THE REPAYE PLAN

III. The Internal REvenue CODE Provisions Relating to FORGIVEN STUDENT LOAN DEBT

IV. THE IMPACT OF THE TAX BOMB ON LAWYERS

A. The Time Frame for Obtaining Debt Forgiveness Under Each of the Plans

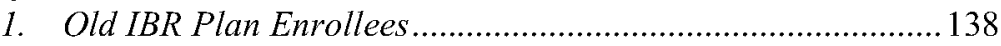

2. PAYE Plan Enrollees ........................................................ 139 


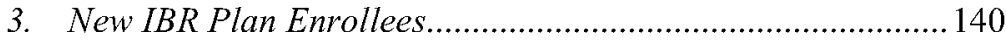

4. ICR Plan Enrollees ................................................................. 140

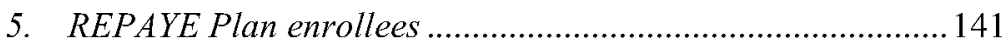

6. All Plan Law Graduate Enrollees Combined.........................141

B. The Distribution of Plan Enrollees Each Year Across the Various Plans.............................................................................. 142

C. The Average Debt Forgiveness Tax Obligation That Will be Imposed on Individual Old IBR and PAYE Plan Law Graduate Enrollees

D. The Number of Lawyers Who Will Receive Debt Forgiveness Each Year Under One or Another of the Plans....

E. The Overall Annual Debt Forgiveness Tax Liability Imposed on Lawyers.

F. The Effects of Inflation on the "Real" Burden Imposed on Lawyers by the Tax Bomb.

V. Defusing the Tax Bomb 185

A. Arguments For and Against Defusing the Tax Bomb

B. Measures to Reduce or Eliminate the Impact of the Tax Bomb upon Lawyers

1. Amendment of the Internal Revenue Code to Eliminate Taxation of Debt Forgiven under the IBR or PAYE Plans..... 193

2. New Treasury Department Regulations to Eliminate or Reduce the Taxation of Debt Forgiven under the IBR or PAYE Plans.

3. Amendment of the Internal Revenue Code to Allow Taxes Imposed on Forgiven Student Loan Debt to be Paid Over a Several-Year Period.

4. Legislative Restriction of the Amount of Loan Debt that can be Repaid under the IBR or PAYE Plans

5. Restoration of the Original IBR Requirement of Monthly Repayments of $15 \%$ of Discretionary Income

\section{INTRODUCTION}

Each year starting in about 2033, thousands and later tens of thousands of lawyers who incurred large student loan debts and who have been able to earn only a relatively modest annual income in the twenty or twenty-five years following their law school graduation will be subject to large 
cancellation of indebtedness-based federal income tax obligations, and often smaller but still significant state cancellation of indebtedness income tax obligations. The combined federal and state income tax bills for lawyers who have enrolled in the federal Pay As You Earn student loan repayment Plan "the PAYE Plan"l since 2013 will often be in the neighborhood of $\$ 50,000$ to $\$ 100,000$, and in some instances even larger. For another large group of lawyers - persons who have enrolled in the federal Income-Based Repayment Plan (hereinafter referred to as the IBR Plan) ${ }^{2}$ since 2009 - the tax obligations will often be in the $\$ 15,000$ to $\$ 25,000$ range.

Many of these lawyers will have failed to adequately provide for this sudden large tax obligation and will find that it will significantly impair their later retirement plans. In addition, each year beginning in 2033, another group of tens of thousands of people who have incurred student loan debts of up to $\$ 50,000$ or more to finance Ph.D. work or other non-legal graduate, professional studies, or undergraduate coursework, and who over the following two decades or more have also been able to earn only relatively modest annual incomes will also face cancellation of indebtedness federal and state income tax bills. While these latter tax bills will usually not be of the same order of magnitude as the large obligations facing many lawyers, they could, in some instances, still be large enough to cause substantial hardship.

I believe the phrase "tax bomb" is an apt description of a large tax obligation that will be imposed in a single year on cancellation of indebtedness income attributed to, but not actually received by, a relatively small group of taxpayers. This tax bomb will result from a substantial portion of the loan debts incurred by many students, especially law students, eventually being forgiven under one or another variant of the increasingly popular income-based federal student loan repayment options ("the "Plans") and treated under the Internal Revenue Code ("the "Code") and applicable state income tax codes as taxable income in the year in which those loan debts are discharged.

In this Article, I will explain how this tax bomb was created and how the various statutes and regulations that define its scope and size have evolved over time. I will then discuss when these tax obligations will come due under each of these Plans and will offer some detailed illustrative calculations regarding the magnitude of the tax bomb's impact upon many

1. Fed. Student Aid, U.S. Dep't of Educ., Income-Driven RePayment Plans FOR FEDERAL STUDENT LOANS 1, 3 (2016), http://studentaid.ed.gov /sa/sites/default/files/income-driven-repayment.pdf.

2. Id. 
lawyers, individually and in the aggregate. ${ }^{3}$ I will also discuss whether measures should be taken to defuse this tax bomb before these obligations begin coming due in 2033, and I will propose and discuss several alternative legislative and administrative measures that might be taken alone or in combination to accomplish this end.

In Part II of this Article, I will discuss the relevant aspects of the two existing variants of the IBR Plan (hereinafter referred to as the "old IBR Plan" and the "new IBR Plan," respectively), as well as those of the closelyrelated PAYE Plan, and of the new Revised Pay As You Earn Plan (hereinafter referred to as the "REPAYE Plan") that first became available for borrower enrollment in July 2016. In Part III of the Article, I will discuss the Code provisions that will impose this cancellation of indebtedness tax obligation on enrollees in these Plans when their remaining unpaid debts are forgiven at expiration of the Plans' required repayment period.

In Part IV of this Article, I will analyze the impact of the tax bomb on law school graduates (hereinafter "law graduates") who have enrolled in one or another of these Plans. I will first discuss the time frame in which these tax obligations will come due as enrollees under each of these Plans eventually qualify for debt forgiveness under the different debt repayment schedules. While the available information is not sufficient to offer with any real confidence precise estimates of the size of the tax bomb problem for affected individuals and in the aggregate, I will do what I can with the limited data that exists and will present what are concededly somewhat speculative, but hopefully realistic and useful calculations regarding: (1) how large the individual tax bills are likely to be for typical law school graduate enrollees under the various Plans; (2) how many law graduate enrollees under the various Plans will be impacted by the tax bomb each year; and (3) how large the aggregate annual tax bill imposed on law graduates is likely to be, starting in 2033, when the first substantial group of PAYE Plan enrollees reach the end of their required twenty-year repayment

3. As noted above in the main text, this cancellation of indebtedness-based tax liability will impact not only law school graduates but also many other persons who have enrolled in one or another of the various existing plans to repay loans taken out to finance other forms of graduate school or professional training and/or to finance their undergraduate studies. However, for reasons that I will later discuss in this Article, it will be much more difficult to estimate the size of the tax bomb impact upon these other borrowers than it will be for law graduate borrowers; both the individual and aggregate impacts will generally be much smaller for these other classes of borrowers than for law graduates. Therefore, in this Article I will focus only upon law graduate plan enrollees. The reader should recognize that the overall impact of the tax bomb will be somewhat larger and perhaps significantly larger, than its impact upon lawyers alone. I will leave the analysis of the overall impact of the tax bomb upon all affected enrollees in one or another of the various plans for another day. 
period and qualify for forgiveness of any remaining debts, and then in each following year for approximately the next decade and a half after that.

Having offered in Part IV estimates of the individual and aggregate impacts of the tax bomb, in Part V, I will consider the policy issues that it presents and the arguments for and against taking steps to mitigate or even eliminate its impact. I will conclude by offering my recommendation that no action be taken to eliminate or mitigate its consequences except for a minor amendment to the Code that would allow those persons subject to cancellation of indebtedness tax liability, due to discharged student loan debt, to pay those taxes over a several-year period after they become due, rather than to require that those taxes all be paid in the year of debt forgiveness, without undue penalty for deferring their payment. However, whether this looming tax bomb calls for more substantial corrective action than simply extending the tax payment period is a close question on which reasonable persons can disagree. I will, therefore, also discuss several other more drastic alternative legislative or regulatory measures by which the tax bomb might be partially or wholly defused. Part VI of the article will present a brief overall conclusion.

\section{Evolution of THE InCOME-BASED REPAYMENT Plans FROM THE "OLD" IBR PLAN THROUGH THE REPAYE PLAN}

Since 2009, the federal government has offered an expanding menu of relatively generous loan repayment options for persons who have incurred federally-provided or federally-guaranteed student loan debt. ${ }^{4}$ In 2007 , Congress established the old IBR Plan which became available for borrower enrollment on July 1, 2009. ${ }^{5}$ The old IBR Plan provides eligible borrowers with loan repayment and debt forgiveness terms which are substantially more attractive than the terms of an earlier and less generous effort to offer borrowers an income-related loan repayment option through the IncomeContingent Repayment Plan ("ICR Plan"). ${ }^{6}$ Most importantly, the old IBR

4. See Fed. STUdent AID, U.S. DeP'T OF EdUC., REPAYING YOUR LoANS 1, 8-11 (2015), http://studentaid.edu.gov/sa/sites/default/files/repaying-your-loans.pdf.

5. 20 U.S.C. $\$ 1098$ e (2012) (originally enacted by the College Cost Reduction and Access Act, Pub. L. No 110-84, § 203, 121 Stat. 784, 792-95 (2007)).

6. See generally Omnibus Budget Reconciliation Act of 1993, Pub. L. No. 103-66, 107 Stat. 346 (1993). The Income-Contingent Repayment Plan, made available for enrollment in 1994, requires borrowers to make repayments of $20 \%$ of their discretionary income and requires those repayments to be made for twenty-five years before any remaining debt is forgiven. FED. STUDENT AID, supra note 1, at 1. It also allows married borrowers who file separate tax returns to use only their own income and not their spouse's income to determine the size of their repayment obligation. 20 U.S.C. $§ 1098 \mathrm{e}(\mathrm{d})$. See Phillip G. Schrag, The 
Plan requires enrollees to make monthly payments that are only equal to $15 \%$ of the difference between the enrollee's adjusted gross income and $150 \%$ of the poverty level income for a family of the enrollee's family size (this difference is hereinafter referred to as the enrollee's "discretionary income"). The old IBR Plan can be used no matter how large the student's debt, ${ }^{7}$ and does not require a married enrollee who files a separate tax return from that of their spouse to include their spouse's income in calculating the size of their monthly repayment obligation. ${ }^{8}$ It also adds to the enrollee's debt obligation but does not capitalize into interest-earning principal any unpaid loan interest, ${ }^{9}$ and forgives any remaining debt owed after twentyfive years of making repayments. ${ }^{10}$

The original terms of the old IBR Plan were made more generous on December 21, 2012 for some, but not all, IBR Plan-eligible borrowers through the issuance of the Department of Education's ("DOE") Pay As You Earn rules, creating the PAYE Plan. ${ }^{11}$ The most important differences between the PAYE Plan and the old IBR Plan are that PAYE Plan enrollees are required to make payments of only $10 \%$ of their discretionary income, no

Federal Income-Contingent Repayment Option for Law Student Loans, 29 HoFsTRA L. REV. 733, 764-74 (2007), for further discussion of the development and technical aspects of the Income-Contingent Repayment Plan. The number of persons making loan repayments under the Income-Contingent Repayment Plan decreased slightly from 630,000 in the third quarter of 2013 to 600,000 in the second quarter of 2014 and has remained at that 600,000 level through the start of the first quarter of 2016 , showing that there have been few if any new enrollments in that plan over the past few years now that more several generous loan repayment plans are available. NAT'L STUDENT LOAN DATA SYS., U.S. DEP'T OF EDUC., Direct Loan Portfolio by Repayment Plan, https:/studentaid.ed.gov/sites/default/files/fsawg/datacenter/library/ DLPortfoliobyRepaymentPlan.xls [hereinafter NAT'L STUDENT LOAN DATA SYS.].

7. 20 U.S.C. $\$ \$ 1098 \mathrm{e}(\mathrm{a})(3)(\mathrm{B}), 1098 \mathrm{e}(\mathrm{b})(6)$, https://studentaid.ed.gov/sites/default files/fsawg/datacenter/library/DLPortfoliobyRepaymentPlan.xls. It is critical to understand that the IBR Plan severs the usual linkage between the size of the debt incurred and the size of the required repayments, dramatically altering borrower incentives. This repayment requirement is subject to the caveat that if an enrollee no longer has a "partial financial hardship" in that the size of his required monthly repayments under the $15 \%$ of discretionary income formula has grown to where it exceeds the amount that he would have owed to repay his debt under a standard 10-year repayment schedule, the enrollee will only for the remainder of the required repayment period (or until the debt is fully repaid, whichever comes first) have to make payments equal to that required by a standard 10-year repayment schedule for the original amount of loan debt. $I d$.

8. See id. $\$ 1098 \mathrm{e}(\mathrm{d})$.

9. Compare 34 C.F.R. $\S 685.209(\mathrm{a})(2)(\mathrm{i})(2016)$, with 20 U.S.C. $\S 1098 \mathrm{e}(\mathrm{a})(3)(\mathrm{B})$ (Supp. II. 2008).

10. Compare 34 C.F.R. $\$ 685.209(\mathrm{a})(6)(\mathrm{i})$, with 20 U.S.C. $\$ 1098 \mathrm{e}(\mathrm{b})(7)(\mathrm{B})$ (Supp. II. 2008).

11. See generally 34 C.F.R. $§ 685.209$ (a) (codifying the PAYE Plan). 
matter how large their debt, rather than $15 \%$, as under the old IBR Plan. ${ }^{12}$ Additionally, enrollees now must make those payments for only twenty years, rather than twenty-five years as under the old IBR Plan, before any remaining unpaid debt is forgiven. ${ }^{13}$ However, importantly, not all persons eligible to enroll in the old IBR Plan are eligible for the PAYE Plan, ${ }^{14}$ nor are all federal loans eligible for repayment under the old IBR Plan eligible for repayment under the PAYE Plan. ${ }^{15}$

Congress, also in 2010 legislation, ${ }^{16}$ made more generous the terms of the old IBR Plan in a manner that matches the $10 \%$ of discretionary income and twenty-year repayment period terms of the later-implemented PAYE Plan, but these terms are only available for those IBR Plan-eligible persons who are also "new" federal student loan borrowers as of July 1, 2014, ${ }^{17}$ thereby establishing another loan repayment option which I will hereafter refer to as the "new IBR" Plan. Most law graduates, however, will not be able to make use of the new IBR Plan until at least $2017 .{ }^{18}$

Finally, yet another loan repayment option was created by the recent implementation of the DOE's new REPAYE Plan. ${ }^{19}$ The proposed rules to govern that Plan were originally agreed to on April 30, 2015, by designated DOE officials and outside negotiators who participated in a negotiated DOE rulemaking process, and after numerous public comments were considered, these rules were finalized, in essentially the same form as proposed, on October 27, 2015. The final rules were issued on October 30,2015 , and allowed for borrower enrollment in the new Plan starting in July, $2016 .^{20}$

12. Id. $\S 685.209(\mathrm{a})(2)(\mathrm{i})$.

13. Id. $\S 685.209(\mathrm{a})(6)(\mathrm{i})$.

14. Id. $\$ 685.209$ (a)(iii). This new IBR Plan is available only to those IBR-eligible borrowers who are also "new" borrowers as of July 1, 2014, in that they had no outstanding Direct Loans or Federal Family Education Loans at that time.

15. 34 C.F.R. $\S 685.209$ (a)(iii) (2016).

16. Health Care and Education Reconciliation Act of 2010, Pub. L. No. 111-152, $\S \S 2201-2213,124$ Stat. 1029, 1071-81 (2010).

17. Id.

18. The first group of law graduates who will be able to make use of the new IBR Plan to repay all of their law school loan debts will be those persons who first enrolled in law school and took out their first federal student loans in the fall of 2014 for the 2014-2015 academic year and who then graduate from law school three years later in 2017. Those law graduates who also took out federal student loans starting in 2014 each year during their undergraduate studies will not be able to enroll in the new IBR Plan until at least 2021.

19. 34 C.F.R. $\$ 685.209$ (c) (2016).

20. See U.S. DEP'T OF EDUC., Draft Proposed Modifications to Existing Regulations 04/30/15 (Apr. 28, 2015), https://www2.ed.gov/policy/highered/reg/hearulemaking/ 2015/Paye3-issuel.doc [hereinafter Draft REPAYE Rules]; Student Assistance General Provisions, Federal Family Education Loan Program, and William D. Ford Federal Direct 
The REPAYE Plan is the result of a rulemaking process that was initiated to implement President Obama's June 2014 directive to the DOE ${ }^{21}$ to substantially expand the eligibility for obtaining loan repayment terms that are comparable to those of the PAYE Plan to include a large group of up to five million "old" borrowers that have enrolled, or are eligible for enrollment, in the old IBR Plan or ICR Plan, but that are not eligible to enroll in the more generous PAYE Plan. Additionally, the REPAYE Plan aimed to focus the benefits of the new REPAYE Plan primarily on the most struggling borrowers. ${ }^{22}$ The REPAYE Plan's substantive rules are accompanied by some technical conforming amendments to mesh with certain other DOE rules that apply to the IBR or PAYE Plans, but the REPAYE Plan importantly leaves open as options for eligible borrowers the ability to enroll in any of these other Plans under their existing terms.

In other words, the REPAYE Plan will only add another debt repayment option to the existing menu of choices, rather than replace or alter any of these other Plans. The DOE could have attempted to have the new REPAYE Plan rules also apply to any new enrollees in the PAYE Plan or in either of the IBR Plans, but chose not to do so. I do not know precisely why the DOE made this decision, but it was probably done for both legal and political reasons. Let me explain this point.

As a legal matter, the DOE could have drafted the REPAYE Plan rules not only to apply to REPAYE Plan enrollees but also to apply prospectively to future PAYE Plan enrollees under the discretion given to the DOE by the legal authority conferred by the statutes creating the Income-Contingent Repayment Plan, and in reliance upon which the original PAYE Plan rules were issued ${ }^{23}$ However, if this sweeping step had been taken, the resulting increase in repayment obligations for hundreds of thousands of future PAYE Plan enrollees over the years resulting from imposition of the REPAYE Plan's new spousal income inclusion rules and longer required repayment period for graduate school borrowers would have far outweighed any benefits conferred on the much smaller group of new REPAYE Plan enrollees - particularly for law graduate PAYE Plan enrollees. This result

Loan Program, 80 Fed. Reg. 67204 (Oct. 30, 2015) (to be codified at 34 C.F.R. pts 668, 682, 685) [hereinafter William D. Ford Federal Direct Loan Program].

21. Memorandum of June 9, 2014, Helping Struggling Federal Student Loan Borrowers Manage Their Debt, 79 Fed. Reg. 33843 OFFICE OF PRESS SEC'Y (June 12, 2014).

22. Jeff Appel, Deputy, U.S. Dep't of Educ., Opening Remarks at the Pay as You Earn (PAYE) Extension Rulemaking Committee Meetings (Feb. 24, 2015).

23. See Federal Perkins Loan Program, Federal Family Education Loan Program, and William D. Ford Federal Direct Loan Program, 77 Fed. Reg. 42,086, 42,099 (proposed July 17, 2012). 
would doubtlessly lead to serious political controversy and badly undercut the increased access to higher education rationale articulated by President Obama in originally calling for DOE action in 2014 to establish a new loan repayment option for borrowers. ${ }^{24}$ It would not only have been similarly politically controversial but also legally problematic for the DOE to attempt to have the REPAYE Plan rules also apply prospectively to future old IBR Plan and new IBR Plan enrollees without first obtaining additional congressional authorization for such action. This is because separate statutes establish each of the two IBR Plans, statutes that are different from the statute establishing the Income-Contingent Repayment Plan and authorizing the subsequent PAYE Plan rules. But by proposing the REPAYE Plan only as a new Plan that left unaltered and still available for borrower enrollment all of the previously existing Plans, the DOE has avoided these legal and political controversies.

The REPAYE Plan differs in important ways from each of the existing Plans. First, it embraces the PAYE Plan and new IBR Plan provisions that require enrollees to make payments of only $10 \%$ of their discretionary income, rather than the substantially larger $15 \%$ of discretionary income that is required under the old IBR Plan. ${ }^{25}$ Second, it utilizes the old IBR Plan's broad eligibility criteria rather than the more restrictive PAYE Plan eligibility criteria, thereby making eligible for enrollment a large group of approximately five million student loan borrowers, persons who took out federal student loans before October 1, 2007, and thus, are not eligible for enrollment under the PAYE Plan or under the new IBR Plan. I estimate that approximately 60,000 out of those five million newly-eligible borrowers are law graduates. ${ }^{26}$ Third, the REPAYE Plan will require a loan repayment

24. See Michael Stratford, Obama Expands IBR, Pushes Refinancing, INSIDE HiGHER ED (June 10, 2014), https://www.insidehighered.com/news/2014/06/10/obama-expandsincome-based-repayment-older-borrowers-pushes-democrats $\% \mathrm{E} 2 \% 80 \% 99$-student-loan.

25. Final REPAYE Rules, 80 Fed. Reg. 67,203, 67,210 (Oct. 30, 2015) [hereinafter Final REPAYE Rules].

26. Let me explain the basis for this estimate. The Obama Administration has not broken down the composition of those five million "old borrowers" that are not eligible for the PAYE Plan who will become eligible for REPAYE Plan enrollment in 2016 by the type of degrees awarded or by the year in which those degrees were rewarded. For 2012-13, the latest year for which comprehensive degree-awarded statistics are available, there were a total of $3,774,000$ associate's degrees, bachelor's degrees, master's degrees, and doctoral degrees awarded, U.S. DEP'T OF EDUC., THE CONDITION OF EDUCATION 200-05 (2015), of which 46,776 were JD or LLB law degrees. ABA, 2013 Law Graduate Employment Data (Apr. 28, 2015), http://www.americanbar.org/content/dam/aba/administrative/legal_education_ and_admissions_to_the_bar/statistics/2013_law_graduate_employment_data.pdf. - So approximately $\overline{(46,776 / 3,774,000)}=1.2 \%$ of the total number of degrees awarded in that 2012-2013 academic year were three-year law degrees. Absent more detailed and law 
period of twenty-five years prior to debt forgiveness, matching the old IBR Plan repayment period requirement, for those enrollees who have taken out graduate or professional school loans (and perhaps also undergraduate loans) rather than only undergraduate loans, while requiring only a twenty-year loan repayment period prior to debt forgiveness, matching that repayment period imposed by the PAYE and new IBR Plans, for those enrollees who have taken out only undergraduate loans. ${ }^{27}$ Fourth, only one-half of the unpaid loan interest that accrues for enrollees during those periods of negative amortization when their required repayments are not sufficient to pay the interest owing on their loans will be added to their debt, rather than all of that unpaid interest as is now done under the IBR and PAYE Plans. ${ }^{28}$

graduate-specific data, I will generalize from this statistic and will assume that also approximately $1.2 \%$ of the 5 million old borrowers who received their degrees distributed over a number of years and who will now become eligible for REPAYE Plan enrollmentapproximately 60,000 persons - will be law graduates.

This is concededly a relatively crude estimation procedure. To the extent that a larger proportion of law graduates takes out federal student loans than do persons earning degrees generally, which is very likely, my estimate will to that extent underestimate the number of old borrower law graduates made newly eligible for REPAYE Plan enrollment. On the other hand, to the extent that the five million persons made eligible for the REPAYE Plan include persons who took out student loans but did not obtain a degree, which is also very likely, my estimate will to that extent overestimate the number of old borrower law graduates made newly eligible for REPAYE Plan enrollment. Estimation errors that stem from these two causes will, therefore, fortunately cancel out, at least to some extent.

27. See Final REPAYE Rules, supra note 25; William D. Ford Federal Direct Loan Program, supra note 20. The initial DOE proposal considered by the REPAYE Plan negotiators had a twenty-year repayment period for borrowers whose loan debt was $\$ 57,500$ or less and a twenty-five-year repayment period for borrowers whose loans exceeded this amount. During the April 28-30, 2015, negotiations, however, primarily because of concerns about creating a "cliff" at this loan amount that would create perverse borrower incentives, this original loan size restriction was changed to the current provision that imposes a twenty-year repayment period for borrowers with only undergraduate loans and a twenty-five-year repayment period for borrowers with graduate or professional school loans (and perhaps also undergraduate loans), regardless of the size of the loans involved. Michael Stratford, Federal Rule-Making Panel Oks Plan to Expand Income-Based Repayment Program, INSIDE HIGHER ED. (May 1, 2015), https://www.insidehighered.com/news $/ 2015 / 05 / 01 /$ federal-rule-makingpanel-oks-plan-expand-income-based-repayment-program [hereinafter Stratford, Federal Rule-Making].

28. See Final REPAYE Rules, supra note 25. Under the PAYE and IBR Plans there are provisions under which the federal government will pay any unpaid interest accruing on subsidized Direct Loans for the first three years after enrollment. However, such subsidized loans have not been made available to law students since 2012, and were never available for more than a relatively small proportion of typical law student loan debt, so I will ignore this minor unpaid interest accrual complication in my later illustrative calculations. This particular REPAYE Plan provision to charge borrowers with only one-half of any unpaid interest also raises a potential issue as to whether the forgiveness of the remainder of the unpaid interest creates a tax liability for the enrollee in the year that it is not paid. 
Finally, the REPAYE Plan rules will now require all married enrollees, even those who file separate tax returns from those of their spouse, to use the couple's combined income for calculating the size of the required monthly repayments, rather than as is now permitted under the IBR and PAYE Plans for an enrollee who files their taxes separately to utilize their income alone for those calculations. ${ }^{29}$

There is a fairly substantial amount of literature that considers the financial problems currently facing many law students and law schools, and which assesses the significance of the IBR Plans and the PAYE Plan for legal education. ${ }^{30}$ I have contributed to that literature with a recent article that comprehensively assesses the consequences of these Plans, and of the closely-related and even more generous Public Service Loan Forgiveness ("PSLF") option," for law graduates and for the financial viability of legal education in the coming years. ${ }^{32}$ That article provides considerable detail

29. See Student Assistance General Provisions, Federal Family Education Loan Program, and William D. Ford Direct Loan Program, 80 Fed. Reg. at 67,214 (June 16, 2016).

30. For a comprehensive discussion of the difficult financial situation facing legal education, see generally PAUL CAMPOS, DON'T GO TO LAW SCHOOL (UNLESS) (2012); BRIAN Z. TAMANAHA, FAILING LAW Schools (2012); Richard W. Bourne, The Coming Crash in Legal Education: How We Got Here, and Where We Go Now, 45 CREIGH. L. REV. 651 (2012); Steven R. Smith, Financing the Future of Legal Education: Not What It Used To Be, 2012 MICH ST. L. REV. 579 (2012). For a briefer summary of the problem, see also Steve J. Harper, Pop Goes the Law, THE CHronicle REVIEW (Mar. 11, 2013), http://www.chronicle.com/article/Pop-Goes-the-Law/137717/.

31. 20 U.S.C. $\$ 1087 \mathrm{e}(\mathrm{m})(2012)$. Persons enrolling in the IBR or PAYE Plans are also eligible to participate in the PSLF option, which does not require formal enrollment. Under the PSLF option if the enrollee can demonstrate that they were employed by a qualified employer for ten years then the remaining unpaid debt is forgiven, and under I.R.C. Section 108(f)(1) there is no tax liability imposed for that forgiven debt. I.R.C. $\$ 108(f)(1)$ (2016). The PSLF option thus provides a model for a possible Code amendment to eliminate altogether the tax bomb consequences, an amendment that I will discuss in Part V of this Article.

32. Gregory Crespi, Will the Income-Based Repayment Program Enable Law Schools to Continue to Provide Harvard-Style Legal Education?, 67 SMU L. REV. 51 (2014) [hereinafter Crespi (2014)]. One of my rather discouraging conclusions reached in that article was that due to the well-publicized sharply reduced demand for highly paid, entry-level law firm associates since 2008, a consequence of both cyclical and structural economic factors, along with the steady increases over recent decades in law school tuitions, most law schools are now facing severe financial pressures from a substantial decline in the number and quality of their applicants, with a significant number of academically and financially weaker law schools likely to eventually have to close. $I d$. at 52 . A second conclusion that I reached was that legal education is rapidly becoming increasingly dependent upon the indirect but quite substantial federal subsidy that law schools benefit from as a result of their students having access to the generous IBR and PAYE Plans' repayment and debt forgiveness terms upon their graduation, and to the PSLF option, with these students and prospective law school applicants thereby often being much less concerned than they otherwise would be with the amount of tuition they will have to pay. Id. at 63-64. If the IBR and PAYE Plans and PSLF option are ever 
regarding the features of the IBR and PAYE Plans, and I will often refer to that earlier work in this Article. The enrollment in the IBR Plans has been rapidly increasing over the past couple of years, ${ }^{33}$ and PAYE Plan enrollment has been increasing at an even more striking rate, ${ }^{34}$ as these Plans' favorable terms have become more widely known to heavily indebted borrowers. Those Plans, with their generous repayment and debt forgiveness terms, have almost completely displaced the previously enacted and less generous Income-Contingent Repayment Plan. ${ }^{35}$

Let me briefly explain when and how the tax bomb will be detonated by the old and new IBR Plans and PAYE Plan and now also by the REPAYE Plan. As discussed above, each Plan imposes its own required repayment period before forgiving any remaining unpaid debt. ${ }^{36}$ Under the PAYE Plan and the new IBR Plan, any remaining outstanding loan debt and accrued unpaid interest thereon is forgiven after the enrollee has made the required minimum repayments for twenty years. ${ }^{37}$ This required repayment period before debt forgiveness is instead twenty-five years under the old IBR Plan. ${ }^{38}$ The REPAYE Plan imposes a twenty-five-year repayment period for those REPAYE enrollees who have taken out federal loans to finance graduate or professional school education (and possibly also undergraduate education) before any remaining debt is forgiven, ${ }^{39}$ and a twenty-year repayment period prior to debt forgiveness for those enrollees who have taken out loans only to finance undergraduate studies. ${ }^{40}$ The tax bomb arises because, under each of these Plans, that forgiven debt is then treated by the Internal Revenue Code and by state tax codes as cancellation of

legislatively amended to eliminate or even only significantly limit the ability of law graduates with large student loan debts to access these favorable terms, the results for all but the most elite law schools would likely be little short of catastrophic. $I d$. at 58 .

33. Enrollment in the IBR Plans has increased from 910,000 enrollees at the start of the third quarter of 2013 to $3,050,000$ enrollees by the start of the first quarter of 2016, an addition of 2,140,000 enrollees, a $235 \%$ increase in enrollment in only two and one-half years. See NAT'L STUDENT LOAN DATA SYS., supra note 6.

34. Enrollment in the PAYE Plan has increased from only 40,000 enrollees to 910,000 enrollees over that same two and one-half year period, an addition of 870,000 enrollees, a huge $2,175 \%$ increase in enrollment over that period! Id.

35. The number of persons making loan repayments under the Income-Contingent Repayment Plan has decreased slightly from 630,000 in the third quarter of 2013 to 600,000 in the first quarter of 2016, showing that there have been few if any new enrollments in that program over the past several years. $I d$.

36. See supra Part II.

37. See supra Part II.

38. See supra Part II.

39. See supra Part II.

40. See supra Part II. 
indebtedness income, as ordinary income that must be recognized in the year of debt forgiveness. ${ }^{41}$

As I have previously discussed at some length in my earlier article on the subject, many law students now incur quite substantial federal loan debts that, in some instances, approach or even exceed $\$ 200,000$ when the interest that accrues on their loans during law school and afterwards, before their repayments begin upon their Plan enrollment, usually done approximately six months after graduation, are added to the original loan debt. ${ }^{42}$ The generous repayment terms of the IBR and PAYE Plans allow such high-debt enrollees with even fairly substantial incomes to make only relatively small monthly repayments that are unrelated to the size of their loans and that are insufficient for many years to cover the interest owing on such large loan debts. $^{43}$ For many of these IBR and PAYE Plan enrollees, their unpaid debt will, as a result, grow over time for many years after their enrollment due to this negative amortization, although this accrued unpaid interest will not be capitalized into interest-bearing principal under any of the Plans. ${ }^{44}$ This negative amortization for some years after enrollment will also be the case for some REPAYE Plan enrollees, although not to the same extent. ${ }^{45}$

As I will also later demonstrate with some hypothetical but detailed and realistic illustrative calculations, a large proportion of the PAYE Plan enrollees who have incurred loan debts to finance their law school studies, and often also their undergraduate studies as well, will as a result have over $\$ 200,000$ and, in some cases, even as much as $\$ 300,000$ or more of unpaid

41. See infra Part III.

42 Crespi (2014), supra note 32, at 74-76.

43 Id. at $85-88$.

44. This statement is subject to the caveat that under the IBR and PAYE Plans the federal government will pay on behalf of the enrollee any accrued and unpaid interest based upon subsidized Federal Direct Loans for the first three years after enrollment, but as I have noted above little if any of the loan debt now incurred by law graduates is subsidized debt that will qualify for this treatment, and I will, therefore, ignore this minor complication in my later illustrative calculations. In addition, when a Plan enrollee changes Plans any unpaid accrued interest is usually capitalized into principal for purposes of the new Plan. Finally, if a particular Plan enrollee's income increases to the point where they cease to have a "partial financial hardship," see supra note 7, at that point all accrued and unpaid interest will be capitalized into interest-earning principal for the remainder of the repayment period, or until the debt is fully repaid. See supra note 5.

45. As I have noted earlier under the REPAYE rules that went into force for new enrollees starting in July, 2016, only half of accrued unpaid interest will be added to the debt, and any spousal income must be included in determining the size of the required repayments, and the repayment period will be extended to twenty-five years. See Final REPAYE Rules, supra note 25 . For both reasons the REPAYE Plan rules will, therefore, reduce the amount of accrued interest that would otherwise have been added to an enrollee's debt because of negative amortization due to inadequate loan repayments. 
principal and accrued interest forgiven at the end of the applicable twentyyear repayment period. ${ }^{46}$ Old IBR Plan enrollees with comparable debt loads, who are required to make significantly larger monthly repayments and to do so for a substantially longer period of time, will still often have $\$ 60,000$ or more in unpaid debt at the end of their twenty-five-year required repayment period. ${ }^{47}$ With such a large amount of forgiven debt included in their income, along with their other earnings for that tax year, these persons will almost all be paying taxes on that forgiven debt at at least a $25 \%$ or $28 \%$ marginal federal income tax rate, and sometimes even at a top-bracket $39.6 \%$ marginal federal income tax rate, on this additional attributed income. ${ }^{48}$ In addition, many states also impose a state income tax on the income recognized by the federal government, ${ }^{49}$ in some instances with relatively high upper-bracket marginal rates that would usually apply given the large size of the debt forgiven. ${ }^{50}$ For a PAYE Plan law graduate enrollee with a $\$ 200,000$ or larger unpaid debt at the time of their debt forgiveness, as I will demonstrate this may well mean a combined federal and state income tax bill on this additional attributed income of around $\$ 70,000$, or even more, and a PAYE Plan enrollee with $\$ 300,000$ or more of forgiven debt may owe additional federal and state income taxes in the neighborhood of $\$ 100,000$ or more. ${ }^{51}$ As I will also later demonstrate, the aggregate annual tax liability that will be borne by these IBR and PAYE Plan law graduate enrollees with large student loan debts and later accrued unpaid interest, starting in about 2033, may reach more than one billion dollars per year by about $2039 .{ }^{52}$

Having to pay a substantial tax bill on forgiven debt is of course a much better position for a person to be in compared to their having to fully repay that debt. That being said, coming up with the funds necessary to satisfy such a sudden large tax obligation that is based upon income attributed, but not received, will nevertheless be a substantial burden for many of those

46. See infra Part IV.C.

47. Id.

48. These estimated tax rates on forgiven debt are based on the current federal and state tax brackets for various levels of income, and do not allow for upward adjustment in the income bracket lower cut-offs to reflect inflation over the next twenty or twenty-five years. If the probable periodic adjustments in the bracket cut-off points in the tax schedules to reflect annual inflation rates in the neighborhood of $3 \%$ are taken into account this would probably reduce the applicable tax rates in 2033 and thereafter to some extent, particularly for smaller amounts of forgiven debt.

49. Crespi (2014), supra note 32, at 90 n. 171.

50. Id.

51. See infra Part IV.B, IV.C.

52. See infra Part IV.B, IV.C. 
enrollees, particularly for those PAYE Plan law graduate enrollees who may have lacked the foresight to plan for this tax liability or who, for other reasons, have not made adequate provisions to set aside the funds necessary to meet this obligation. Payment of additional income taxes of $\$ 70,000$ or more may well require significant depletion or even exhaustion of the savings that they have intended to cover their retirement expenses, and perhaps even the liquidation of their other savings and home equity.

This Article will focus exclusively upon the impact of the tax bomb on those Plan enrollees who have obtained law school degrees, and who in so doing have often incurred large six-figure student loan debts. I will not in this Article attempt to estimate the amounts of individual and aggregate debt forgiveness tax liability that may each year face Plan enrollees who have incurred significant debts pursuing medical school or Ph.D. degrees or other non-legal graduate school or professional degrees. ${ }^{53}$ Nor will I attempt to estimate the individual and aggregate debt forgiveness tax liability that may each year face those Plan enrollees who have taken out student loans only to

53. See U.S. DEP'T OF EDUC., FED. STUDENT AID, supra note 1, at 2. I will, however, note in passing that those persons studying for MD degrees or MBA degrees who later enroll in one or another of these repayment Plans will generally be able to later earn sufficient income to largely or fully repay their student loan debts over the next twenty or twenty-five years, and thus will usually avoid later debt forgiveness tax obligations. In addition, persons who study towards Ph.D. degrees or other advanced degrees outside of legal or medical or business education generally incur far smaller debts than do most law or MD or MBA students since they are quite often able to avail themselves of tuition waivers, graduate assistant stipends, and/or outside grant funding to cover much of their expenses. If those latter persons subsequently enroll in one or another of the Plans they will generally be able to discharge their generally relatively small loan debts before the end of their repayment period. They will, therefore, not usually incur any debt forgiveness tax liability at the end of their repayment period.

There is, however, a great deal of variation in the amount of income people will be able to earn over the next twenty or twenty-five years after studying for and sometimes earning Ph.D. degrees or other non-legal graduate or professional degrees, and some Plan enrollees will not be so fortunate as to be able to fully repay their loan debt. One should not overlook the fact that the required monthly payments under any of the Plans for a particular enrollee who has incurred a $\$ 40,000$ to $\$ 50,000$ or so loan debt for their graduate studies, and who then is unfortunately able to earn only a relatively modest annual income over the next twenty or twenty-five years after enrollment, or who must support a relatively large family, or both, may be so small that those payments may not even cover the interest owing on their loans. This also will lead to negative amortization of the loans and the building up of a fairly substantial debt to be forgiven at the end of the applicable twenty- or twenty-five-year repayment period. A forgiven debt in the neighborhood of $\$ 50,000$ or so will usually result in federal and state combined income tax liability that could easily be in the neighborhood of $\$ 10,000$ to $\$ 15,000$ or even somewhat larger. Tax obligations of such amounts, while not of the same order of magnitude as the much larger tax obligations that will be imposed on many PAYE Plan law graduate enrollees, will still be large enough to create significant hardships in some cases. 
finance their undergraduate studies. ${ }^{54}$ My illustrative calculations should therefore be regarded as only establishing an approximate "lower bound" that is well below the total size of the tax bomb. More work will need to be done to estimate the additional impacts of the tax bomb upon Plan enrollees other than law graduates in order to assess its overall social impact.

\section{The Internal Revenue Code Provisions Relating to Forgiven STUDENT LOAN DEBT}

Under Section 61(a)(12) of the Internal Revenue Code, a federal taxpayer must include in their gross income "income from discharge of indebtedness." 55 Section 108 of the Code then provides for two exclusions that are here relevant that limit the scope of this required inclusion of discharged debt in gross income. ${ }^{56}$ First, sub-section $108(f)(1)$ excludes

54. Id. However, let me offer a few brief comments regarding the impact of the tax bomb upon Plan enrollees who have borrowed only to finance undergraduate studies. The federal government currently limits total federal student loan borrowing for studies in pursuit of undergraduate degrees to a total of $\$ 57,500.34$ C.F.R. $\S 685.203$ (e) (2016). Moreover, most undergraduate students who take out federal student loans borrow much less than this capped maximum amount. The majority of persons who borrow only to study towards undergraduate degrees and who later enroll in one or another of the Plans will also generally earn sufficient income to fully or almost fully repay their relatively small loans (when compared to the size of typical law graduate loans) during the applicable repayment period.

There is, however, a great deal of variation in the amount of income people will be able to earn over the next twenty or twenty-five years after studying for and sometimes earning undergraduate degrees, and some IBR and PAYE Plan enrollees will not be so fortunate as to be able to fully repay their loan debt. One should not overlook the fact that the required monthly payments under the Plans for a particular enrollee who has incurred perhaps a $\$ 40,000$ to $\$ 50,000$ loan debt for their undergraduate studies, and who then is unfortunately able to earn only a relatively modest annual income over the following decades after enrollment, or who must support a relatively large family, or both, will be so small that those payments may not even cover the interest owing on their loans. This also will lead to negative amortization of the loans and the building up of a fairly substantial debt to be forgiven at the end of the applicable twenty- or twenty-five-year repayment period. A forgiven debt in the neighborhood of $\$ 50,000$ or so will usually result in federal and state combined income tax liability that could easily be in the neighborhood of $\$ 10,000$ to $\$ 15,000$ or even somewhat larger.

Tax obligations of such amounts, while not of the same order of magnitude as the much larger tax obligations that will be imposed on many PAYE Plan law graduate enrollees, will still be large enough to create significant hardships in some cases. And given the relatively large number of Plan enrollees repaying only undergraduate debts a fairly substantial number of enrollees may eventually find themselves in this position, and therefore the total federal and state debt forgiveness income taxes imposed annually on these enrollees could amount to a fairly substantial sum.

55. I.R.C. $\S 61(1)(\mathrm{a})(12)(2012)$.

56. I.R.C. $\$ 108(2012)$. 
discharged federal student loans from gross income if the terms of the loan provide for discharge of unpaid debt if the borrower "worked for a certain period of time in certain professions for any of a broad class of employers." $" 57$ This provision provides the basis for not imposing any debt forgiveness tax liability upon those persons who take out federal student loans that now generally so provide and subsequently work for any of a broadly-defined class of PSLF-qualified employers for at least ten years. ${ }^{58}$ Under the PSLF option, after an enrollee makes ten years of modest PAYE Plan-level monthly debt repayments $(10 \%$ of the enrollee's discretionary income), the often substantial remaining unpaid loan debt of the enrollee is discharged, ${ }^{59}$ and under Code sub-section $108(f)(1)$, there is not imposed any income tax liability as a result of this debt discharge. ${ }^{60}$ This exclusion does not, however, extend to allow exclusion of discharged debt from gross income by IBR, PAYE, or ICR Plan enrollees who have not worked for ten years or more for PSLF-qualified employers. ${ }^{61}$

Second, Code sub-sections 108(a)(1)(B) and 108(a)(3) together provide for a narrow insolvency exclusion from gross income that applies to the extent that the person whose debt was discharged is insolvent when the discharged debt is considered along with that person's other assets and liabilities. $^{62}$ In other words, to the extent that a person is balance-sheet insolvent at the time of debt discharge, when all of his or her assets and liabilities are considered, including the debt to be discharged, that portion of the discharged debt that puts that person into insolvency, which in some circumstances may include all of that discharged debt, will not give rise to income tax liability. However, for purposes of determining the applicability of this exclusion, a person's assets are very broadly defined to include collectibles, personal property, and those assets that serve as collateral for debts, as well as interests in pension plans or retirement accounts that are beyond the reach of creditors, and the cash surrender value of life insurance

57. I.R.C. $\$ 108(\mathrm{f})(1)$.

58. See id.; 20 U.S.C. $\$ 1087 \mathrm{e}(\mathrm{m})(3)(\mathrm{B})$.

59. 20 U.S.C. $\S 1087 \mathrm{e}(\mathrm{m})(1)(\mathrm{B})(\mathrm{i})(\mathrm{ii})$.

60. I.R.C. $\S 108(\mathrm{f})(2)(\mathrm{D})(\mathrm{ii})$.

61. Jonathan M. Layman, Forgiven But Not Forgotten: Taxation of Forgiven Student Loans Under the Income-Based-Repayment Plan, 39 CAP. U. L. REV. 131, 151-55 (2011); see also Rev. Rul. 08-34, 2008-28 I.R.B. 76 (explaining that $\$ 108(f)(1)$ also excludes from gross income forgiven loans that have been made to law students by law schools under their Loan Repayment Assistance Programs that also condition such forgiveness upon the borrower working for a certain minimum period of time in qualifying law-related public service positions but such debts owed to law schools would not qualify for repayment through the IBR or PAYE or ICR Plans).

62. I.R.C. $\S 108(\mathrm{c})(3)$. 
policies. ${ }^{63}$ The large majority of IBR or PAYE Plan law graduate enrollees will, by twenty or twenty-five years after graduation, probably have accumulated some significant assets by this very broad definition and are therefore not likely to benefit significantly, if at all, from this insolvency exclusion, even if they have relatively large debts forgiven. I will, therefore, not take into account in my later calculations any possible limiting effects on Plan enrollee tax liability that this exclusion may provide.

The provision of the new REPAYE Plan that provides that the federal government will now charge only one-half of the unpaid interest to an IBR or PAYE Plan enrollee's debt balance when the enrollee's payment is not sufficient to cover the interest owed on the outstanding loan balance raises a potential tax law issue.$^{64}$ One could reasonably argue that the other half of the unpaid interest that is not added to the enrollee's outstanding loan balance should be characterized as "forgiven debt" that does not qualify for exclusion from gross income under Code section 108, and therefore should be regarded as taxable income in that year. Under this interpretation of the new REPAYE Plan rules, the provision that limits the accrual of unpaid interest would not actually reduce an enrollee's debt forgiveness tax liability, but would merely accelerate some of that tax liability forward in time from the end of the required repayment period to the year in which that one-half portion of the accrued but unpaid interest was not charged to the enrollee's debt. Such an interpretation of this provision would then burden student loan servicers with annually providing to all REPAYE Plan enrollees records as to the amount of unpaid interest that was not charged to their accounts each year, and, also, would require those enrollees to include those forgiven interest sums in their taxable income for that year. This would be a substantial administrative burden for both loan servicers and REPAYE Plan enrollees.

On the other hand, the fact that under both the IBR and PAYE Plans, the federal government pays any accrued but unpaid interest on subsidized (but not unsubsidized) federal Direct Loans for the first three years after Plan enrollment ${ }^{65}$ government payment is not now regarded as taxable income

63. I.R.S., PUB. 4681, CANCELED DEBTS, FOREClOSURES, REPOSSESSIONS, AND ABANDONMENT 5, 8 (2016) (including among other items various forms of personal property, interests in retirement accounts and pension plans and the cash value of life insurance as relevant assets). One could perhaps challenge such a broad definition of what constitutes assets for the purposes of the insolvency exclusion as being in conflict with the general Congressional intent of linking the imposition of tax liabilities to a taxpayer's ability to pay those taxes.

64. See Final REPAYE Rules, supra note 25.

65. See 34 C.F.R. $\$ \S 685.221$ (b)(3) (2016), 685.209(a)(2)(iii) (2016). 
for the enrollee supports an alternative interpretation of the new REPAYE Plan rules not to impose tax liability for this unpaid interest that is not charged to the borrower's outstanding loan balance. This exemption from taxation is presumably allowed on the basis of a distinction made between unpaid interest debts that have accrued and have been added to a person's debt obligation, but are later forgiven, and interest debts that never initially accrue because another party makes the required interest payments when due on behalf of the borrower. This is a rather delicate, and perhaps contestable, distinction where, as is the case here for federal student loans, the lender is also the person making the interest payments on behalf of the borrower. One could instead regard this process of a lender "paying itself interest" as essentially equivalent to forgiving unpaid interest, thus triggering tax liability under Code section 61(a)(12). But given that this distinction has apparently so far sufficed as a basis to avoid imposing tax liability on IBR and PAYE Plan enrollees for unpaid interest on any subsidized Direct Loans for the first three years after their enrollment, it would appear to extend with equal plausibility to the situation of the government now not charging borrowers with one-half of their unpaid interest obligations under the new REPAYE Plan rules. Therefore, for the remainder of this Article, I will assume that unpaid interest that is not charged to an enrollee's account under the REPAYE Plan's rules will not be regarded as taxable income, either in the year that it was not paid or anytime thereafter, including the year of final debt forgiveness.

As I will discuss more fully in Part $\mathrm{V}$ of this Article, one can immediately see that the tax bomb could be completely eliminated by a small but significant amendment of Code sub-section 108(f)(1) that would broaden the current public service employment-based exclusion of forgiven debt from gross income to apply also with regards to all Plan enrollees who make their required repayments for the entire twenty- or twenty-five-year required repayment period, regardless of their post-enrollment employment history. ${ }^{66}$

In addition, as Professor John Brooks has recently and persuasively argued, the Treasury Department may well have the authority to administratively exclude forgiven student loan debt from taxable income under these Plans, if the Administration is so inclined. ${ }^{67}$ Brooks offers several alternative bases for such exclusion that might be pursued. First, he argues that the amount of student loan debt forgiven by the IRS under one or

66. Layman, supra note 61 , at $138-39$.

67. John R. Brooks, Treasury Should Exclude Income From Discharge of Student Loans, 152 TAX NoTEs 751, 752 (2016). 
another of the Plans could be credibly deemed by Treasury regulation to be a "qualified scholarship" that is excluded from income under Code section $117{ }^{68}$ Second, he argues that the insolvency provision of Code section 108(a)(1)(B) could be administratively defined by the Treasury to exclude a broad range of assets in determining taxpayer insolvency, thereby making that exclusion available to a broader group of Plan enrollees. ${ }^{69}$ Third, he argues that the forgiven debt can be reasonably regarded as merely a contingent liability for which the contingency condition did not occur, rather than as discharged debt that would be subject to taxation. ${ }^{70}$

Finally, Brooks argues that the borrower's original enrollment in one of the Plans after their graduation arguably constitutes a "significant debt modification." 71 While such a modification would normally call for immediate inclusion of any forgiven debt in income under Code section $108(e)(10)$, in this instance there is the practical inability to value the new Plan debt instrument, since the payments are contingent on future income, as well as the practical inability to value the old debt instrument because of the continual availability to the obligee of changing to the IBR option. ${ }^{72}$ In Brooks' view, in light of these severe valuation difficulties, the IRS should simply ignore the modification transaction for tax purposes. ${ }^{73}$

One or more of these regulatory approaches could be pursued by a subsequent Administration that wants to minimize or eliminate the tax bomb, but that is politically constrained from doing so by a reluctant Congress. I will also discuss these option more fully in Part V.

\section{THE IMPACT OF THE TAX BOMB ON LAWYERS}

The looming tax bomb is going to have its greatest impact on those Plan law graduate enrollees who have incurred large six-figure loan debts to finance their law school studies, and often also their undergraduate studies, but who ultimately are able to earn only relatively modest incomes for the next twenty to twenty-five years after graduation. Those persons will benefit greatly from their Plan enrollment because of the very modest monthly repayment obligations those Plans impose - which for many enrollees will for years be substantially less than even the interest accruing on their loan debts-but they will then later face significant debt forgiveness tax

\footnotetext{
68. Id. at 754

69. Id. at 755 .

70. Id. at 756 .

$71 \mathrm{Id}$.

72. Id. at $756-57$.

73. Id. at 757 .
} 
liabilities, particularly the PAYE Plan enrollees. I will, therefore, in this Part IV of the Article, focus exclusively on the circumstances of these Plan law graduate enrollees.

I will, first of all, identify the time frame under which law graduate enrollees in each of the several Plans will qualify for debt forgiveness and thereby possibly incur tax liability. I will then estimate the amount of tax liability that hypothetical "average" law graduates enrolled in either the old IBR Plan or the PAYE Plan-which as I will later discuss are and will continue to be by far the two most heavily utilized Plans - will bear after completing their required repayment period and having their remaining debts forgiven. I will next estimate how many law graduates have enrolled or will enroll each year over the next fifteen years or so in one or another of these Plans and will then later qualify for debt forgiveness. Finally, I will bring together these individual tax liability estimates for different hypothetical average Plan enrollees with the estimates that have been made regarding how many enrollees in each Plan will qualify for debt forgiveness each year, in order to project the aggregate amount of debt forgiveness tax liability that will be borne by Plan law graduate enrollees in each year for the fifteen years beginning in 2033. The reader should keep in mind that this aggregate debt forgiveness tax liability estimate will not include the tax liability that will be imposed upon many other Plan enrollees whose student loan debts financed non-law graduate or professional studies, or only undergraduate studies, and that it therefore should be regarded as only a very conservative "lower bound" estimate of the magnitude of the overall tax bomb.

\section{A. The Time Frame for Obtaining Debt Forgiveness Under Each of the Plans}

Let me first separately identify the time frames under which the enrollees of each of the different Plans will become eligible for debt forgiveness. I will then combine those different Plan debt forgiveness schedules into a single overall debt forgiveness schedule.

\section{Old IBR Plan Enrollees}

The old IBR Plan first allowed eligible persons to enroll after July 1, 2009. Given the twenty-five-year repayment period imposed by that Plan, those initial 2009 enrollees, if they remain enrolled in the Plan and make all of their required repayments as scheduled, will qualify for debt forgiveness 
in 2034. Later 2010 enrollees will become eligible for debt forgiveness in 2035; 2011 enrollees will become eligible in 2036 ; and so on, indefinitely. ${ }^{74}$

\section{PAYE Plan Enrollees}

The PAYE Plan first allowed eligible persons to enroll after December $21,2012,{ }^{75}$ so that 2013 was essentially the initial year for PAYE Plan enrollment. Given the twenty-five-year repayment period imposed by that Plan, those initial 2013 enrollees, if they remain enrolled in the Plan and make all of their required repayments as scheduled, will qualify for debt forgiveness in $2033 .^{76}$ Later 2014 enrollees will become eligible for debt forgiveness in 2034; 2015 enrollees will become eligible in 2035; and so on, indefinitely. ${ }^{77}$

74. Let me note one minor qualification to this debt forgiveness schedule for old IBR Plan enrollees. For any old IBR Plan enrollees who were enrolled in the ICR Plan prior to changing to the old IBR Plan in 2009 or afterwards, any period of debt repayments that they have made under the ICR Plan prior to their old IBR enrollment will count towards the required twenty-five years of repayments before they become eligible for debt forgiveness. So, for example, if a law graduate had enrolled in the ICR Plan at the earliest opportunity to do so in 1994, and then had made all of their regular required repayments prior to changing to old IBR Plan enrollment in 2009, they would then qualify for debt forgiveness as early as 2019 . However, there are likely to be relatively few old IBR Plan law graduate enrollees who made debt repayments under the ICR Plan prior to 2009 , so I will for this tax liability analysis ignore this minor complication and will assume that all of the old IBR Plan enrollees will not qualify for debt forgiveness until twenty-five years after their old IBR Plan enrollment in 2009 or thereafter.

75. See 34 C.F.R. $\$ 685.209$ (a) (2012).

76. See id.

77. Let me note one minor qualification to this debt forgiveness schedule for PAYE Plan enrollees. For any PAYE Plan enrollees who made any loan repayments on their postOctober 1, 2007, prior to 2013 under the standard ten-year repayment schedule, or under the old IBR or ICR Plans, those repayments will count towards the required twenty years of repayments before they become eligible for debt forgiveness. So, for example, if a law graduate had enrolled in the PAYE Plan at the earliest opportunity to do so in 2013, but had been making repayments on his post-October 1, 2007, loans since 2008, he would then qualify for debt forgiveness in 2028 after making twenty years of loan repayments. However, there are likely to be very few PAYE Plan law graduate enrollees who made any debt repayments on post-October 1, 2007, federal loans prior to 2013, so I will ignore this minor complication for this for liability analysis and will assume that all of the PAYE Plan enrollees will not qualify for debt forgiveness until twenty years after their enrollment in 2013 or thereafter. 


\section{New IBR Plan Enrollees}

The new IBR Plan first allowed eligible persons to enroll after July 1, $2014{ }^{78}$ Given that only those persons who first took out federal student loans after July 1, 2014, are eligible to enroll in the new IBR Plan, the very first persons who have incurred qualifying post-July 1, 2014, student loan debts that now wish to repay under that Plan are not likely to enroll until at least 2015. Under the twenty-year repayment period required by that Plan, if those initial enrollees remain enrolled in the Plan and make all of their required repayments they will qualify for debt forgiveness in $2035^{79}$ However, the first law graduates who have at least partially financed each year of their three-year legal education with post-July 1, 2014 student loans, and who do not have any outstanding pre-July 1, 2014 undergraduate loans, will not be able to enroll until $2017 .^{80}$ If they do enroll in 2017 , remain enrolled in the Plan, and make all of their required repayments as scheduled, they will later become eligible for debt forgiveness in $2037 .^{81}$ Later 2018 new IBR Plan law graduate enrollees will become eligible for debt forgiveness in 2038; 2019 enrollees will become eligible in 2039; and so on, indefinitely. ${ }^{82}$

\section{ICR Plan Enrollees}

The ICR Plan first allowed borrowers to enroll in 1994. Under that Plan's twenty-five-year required repayment schedule, those initial 1994 law graduate enrollees, if they remain enrolled in the Plan and make all of their required repayments as scheduled, will qualify for debt forgiveness in 2019. Later 1995 enrollees will become eligible for debt forgiveness in 2020; 1996 enrollees will become eligible in 2021; and so on, though the 2008 ICR Plan enrollees will become eligible for debt forgiveness in 2033.

I will, however, ignore these ICR Plan enrollees in my subsequent tax liability analysis for two reasons. First, enrollment in the ICR Plan

78. See Health Care and Education Reconciliation Act of 2010, Pub. L No. 111-152, $\$ 2213,124$ Stat. 1029,1081 .

79. See id.

80. These students will be persons who first enrolled in law school in the fall of 2014 with no outstanding undergraduate federal student loan debts, and then subsequently incurred post-July 1, 2014, loan debts for law school that left them eligible for new IBR enrollment, and then will graduate from law school in the spring of 2017 and enroll in the new IBR Plan later that same year. It will not be until 2021 that those law graduates who did take out federal loans each year during their undergraduate education will be eligible for new IBR Plan enrollment.

81. See Health Care and Education Reconciliation Act $\S 2213$.

82. See id. 
essentially ceased in 2009 once the substantially more generous old IBR Plan became available, and those law graduates who enrolled in the ICR Plan between 1994 and 2008 (which I estimate as only about a total of 9,000 persons over those fifteen years) graduated from law school with, on average, substantially smaller combined undergraduate and law school debt loads than the $\$ 160,000$ average debt load of more recent law graduates. Second, given the ICR Plan's very substantial $20 \%$ of discretionary income repayment requirement and long twenty-five-year required repayment period, even those law graduate enrollees with relatively high debt loads and relatively modest incomes over the following decades are likely to be able to fully or almost fully repay their debt, and therefore will not have to bear any significant debt forgiveness tax liability. I will, therefore, ignore in this analysis the minor complication posed by the small amount of debt forgiveness tax liability that may be borne by a few ICR Plan enrollees from 2019 through 2033.

\section{REPAYE Plan enrollees}

The REPAYE Plan first became available for enrollment in July, $2016 .{ }^{83}$ Given the twenty-five-year repayment period imposed by that Plan upon law graduate enrollees, those initial 2016 law graduate enrollees, if they remain enrolled in the Plan and make all of their required repayments as scheduled, will qualify for debt forgiveness in $2041 .^{84}$ Later 2017 enrollees will become eligible for debt forgiveness in 2042; 2018 enrollees will become eligible in 2043; and so on, indefinitely. ${ }^{85}$

\section{All Plan Law Graduate Enrollees Combined}

Let me now combine these different Plan debt forgiveness eligibility schedules into a single overall law graduate debt forgiveness schedule. ${ }^{86}$ The different debt forgiveness timing provisions among the four Plans unfortunately make this overall schedule somewhat complicated.

The first Plan law graduate enrollees to become eligible for debt forgiveness will be the initial 2013 PAYE Plan enrollees, who will qualify in

83. Final REPAYE Rules, supra note 25.

84. See id. at 67,205 .

85. See id.

86. As noted above, in preparing this overall debt forgiveness schedule I will ignore the minor complications presented by pre-enrollment debt repayments that may have been made by a few old IBR or PAYE Plan enrollees, or by the possibility that some ICR Plan enrollees may eventually qualify for debt forgiveness. 
2033, after twenty years of repayments. In 2034, the 2014 PAYE Plan enrollees, then completing their twenty-year repayment period and qualifying for debt forgiveness, will then be joined by the initial group of 2009 old IBR enrollees who will have then completed their twenty-five repayment period. In 2035, the 2015 PAYE Plan enrollees and the 2010 old IBR Plan enrollees will similarly qualify for debt forgiveness; and in 2036, the 2016 PAYE Plan enrollees and the 2011 old IBR Plan enrollees will reach maturity in their respective plans' schedules.

Starting in 2037, the PAYE Plan and old IBR Plan law graduate enrollees qualifying each year for debt forgiveness under their twenty- or twenty-five-year repayment schedules will be joined by at least a small cohort of new IBR Plan law graduate enrollees who enrolled in 2017 or thereafter and will at that time have also become eligible for debt forgiveness after twenty years of making the required repayments. Enrollees under each of these three Plans will continue to qualify for debt forgiveness from 2038 through 2040. Finally, in 2041 and thereafter, the enrollees qualifying for debt forgiveness under one or another of these three Plans will begin to be joined each year by a cohort of REPAYE Plan law graduate enrollees who enrolled in 2016 or later, and who will have also become eligible for debt forgiveness after having satisfied their twenty-five-year loan repayment obligations. For reasons that I will discuss below, the number of law graduates that enroll in the REPAYE Plan rather than the PAYE Plan or the new IBR Plan is likely to be very small.

\section{B. The Distribution of Plan Enrollees Each Year Across the Various Plans}

As I will later demonstrate in some detail, the amount of debt forgiven and the consequent size of the income tax liability imposed on Plan law graduate enrollees is likely to be substantially greater for new IBR Plan and PAYE Plan enrollees than for old IBR Plan or REPAYE Plan enrollees who have comparable initial debt loads and comparable income and family size profiles after enrollment. This result stems from the significantly smaller monthly repayments and shorter repayment periods required by those first two Plans compared to the two latter Plans. ${ }^{87}$ The aggregate amount of tax liability imposed on Plan law graduate enrollees that qualify for debt forgiveness each year will thus depend heavily upon the relative distribution of those qualifying enrollees across the different Plans. I will, therefore,

87. In addition, the new IBR Plan and the PAYE Plan do not require the inclusion of spousal income in determining the size of the required repayments, as does the REPAYE Plan. 
spend some time analyzing the likely distribution of law graduate enrollments across these different Plans.

There are likely to be a couple of pronounced shifts over time in the relative proportions of law graduate enrollees across these different Plans who will qualify for debt forgiveness each year between 2033 and the late2040 's. Let me explain why this will be the case. Initially, in 2033, all of the law graduates qualifying for Plan debt forgiveness will be 2013 PAYE Plan graduates, since even the earliest 2009 old IBR Plan enrollees will not yet have qualified for debt forgiveness by that year. In 2034, however, this will change dramatically. The persons qualifying for debt forgiveness in 2034 will be a mixture of 2014 PAYE Plan enrollees and 2009 old IBR enrollees, with the old IBR enrollees who did not have the option of PAYE Plan enrollment at that time probably being the majority of persons qualifying. From 2035 through 2037, a large proportion of Plan enrollees qualifying for debt forgiveness, probably still the majority of those enrollees, will be old IBR enrollees who enrolled between 2010 and 2012 and who, again, did not have the option during those years to enroll in the not-yet-adopted PAYE Plan.

However, the proportion of Plan enrollees qualifying for debt forgiveness between 2034 and 2037 that are PAYE Plan enrollees will gradually increase over that time period, for a couple of reasons. First, the PAYE Plan has become increasingly popular among law graduates over the years as its generous terms have become better known. Second, and probably more importantly, a greater and greater proportion of new law graduates each year meet the PAYE Plan threshold eligibility criteria of having no outstanding pre-October 1,2007, federal student loans, and eligible graduates will surely choose more generous PAYE Plan (or new IBR Plan) enrollment over old IBR Plan enrollment. From 2013 onwards, no law graduates have enrolled (or will enroll) in the old IBR Plan if they know about and are eligible for the PAYE Plan, with its substantially lower required monthly repayments and significantly shorter required repayment period. The proportion of Plan enrollees that will qualify for debt forgiveness from 2038 onwards that are old IBR Plan enrollees will, therefore, gradually dwindle to insignificance as fewer and fewer law graduates have outstanding pre-October 1, 2007, student loans that disqualify them from PAYE Plan eligibility. Consequently, the proportion of Plan enrollees qualifying for debt forgiveness who are PAYE Plan (or new IBR Plan) enrollees will steadily increase each year, eventually reaching $100 \%$.

In brief summary, in 2033 all of the (relatively few) Plan law graduate enrollees qualifying for debt forgiveness will be 2013 PAYE Plan enrollees whose twenty-year required repayment period has expired. In 2034, 
however, the majority of Plan law graduate enrollees qualifying for debt forgiveness will be the initial 2009 old IBR Plan enrollees whose twentyfive-year required repayment periods will have expired. The proportion of Plan enrollees qualifying for debt forgiveness that are old IBR Plan enrollees will then gradually decline from 2035 onwards, with the decline likely becoming more rapid from 2038 onwards, as a larger and larger proportion of new law graduates each year will qualify for the more advantageous PAYE Plan enrollment. The PAYE Plan (and new IBR Plan) will eventually completely displace the old IBR plan as the PAYE Plan eligibility October 1, 2007, initial loan cut-off date and the July 1, 2014, new IBR initial loan cut-off date gradually recede into the distant past.

The above analysis is complicated somewhat by the fact that starting in 2016 the approximately 60,000 law graduates that have taken out federal student loans prior to October 1,2007, and who therefore are not eligible for PAYE Plan enrollment, will have the additional choice of enrolling in the REPAYE Plan rather than in the old IBR Plan or ICR Plan. However, those law graduates have been eligible for enrollment in the old IBR Plan from six months after their graduation onwards since mid-2009, and eligible for ICR Plan enrollment since 1994, and the large majority of them have probably already enrolled in one or the other of those Plans. ${ }^{88}$ In addition, as discussed above, each cohort of new law graduates from 2016 onwards will have only a very small (and steadily declining) proportion of persons who are not eligible for PAYE Plan (or new IBR Plan) enrollment who would even consider REPAYE Plan enrollment.

Starting in July, 2016, those relatively few law graduates who are not eligible for PAYE Plan enrollment and who have already enrolled in the old IBR Plan will have to consider whether to change Plans and enroll in the newly available REPAYE Plan. Whether the REPAYE Plan will be sufficiently more advantageous to a particular person in that group than the old IBR Plan that they are enrolled in to justify changing their enrollment to that new Plan will depend on the person's financial circumstances, specifically their expectations as to the likelihood of significant spousal income over the repayment period.

88. By the first quarter of $2016,3,050,000$ persons had enrolled in the old IBR Plan. See supra note 33. I estimate that about $1.5 \%$ of these old IBR Plan enrollees are law graduates, a total of $3,050,000 \times .015=45,750$ persons. I similarly estimate that about $1.5 \%$ of the about 600,000 ICR Plan enrollees are law graduates, a total of about $600,000 \times .015=9,000$ persons. So by my calculations about $45,750+9,000=54,750$ persons, over $90 \%$ of the estimated 60,000 law graduates that are not eligible for PAYE Plan enrollment, and who were in July, 2016 now presented with the new REPAYE Plan option, will have already enrolled in either the old IBR Plan or the ICR Plan. 
Let me explain this point. Both the old IBR Plan and the REPAYE Plan will require twenty-five years of loan repayments by law graduate enrollees. However, the REPAYE Plan has an advantage over the old IBR Plan in that it requires that the enrollee to make repayments of only $10 \%$ of their discretionary income, while the old IBR Plan requires larger repayments of $15 \%$ of discretionary income. In addition, the REPAYE Plan forgives onehalf of any unpaid accrued interest during periods of negative amortization, while the old IBR Plan does not. On the other hand, under the REPAYE Plan a married enrollee will have to include any spousal income in determining their size of his discretionary income, which could increase those required repayments substantially, whereas an old IBR Plan enrollee does not have to do this if they file a separate tax return.

If a prospective Plan enrollee has a spouse whose future income is expected to increase the family's discretionary income by less than $50 \%$ each year, on average, the REPAYE Plan will require smaller monthly repayments than will the old IBR Plan. But if the expected spousal income will increase the family's discretionary income by more than $50 \%$ each year, on average, however, the old IBR Plan will likely prove more advantageous, assuming that the enrollee files a separate tax return. ${ }^{89}$ As a rough rule of thumb, if the spouse's expected annual adjusted gross income will average more than about $33 \%$ of the enrollee's adjusted gross income over the entire required repayment period, this will increase the REPAYE Plan repayment requirements sufficiently that the old IBR Plan will likely prove more advantageous to the enrollee. ${ }^{90}$

89. If an enrollee's spousal income increases the family's discretionary income by exactly $50 \%$, then the REPAYE Plan's required repayments of $10 \%$ of that larger family's discretionary income will be exactly equal in size to the required repayments made under the old IBR Plan's requirement of $15 \%$ of the amount of discretionary income based only on the enrollee's adjusted gross income. If the spousal income increases the family's discretionary income by less than $50 \%$, there will, therefore, be some benefit to old IBR Plan enrollees of switching to the REPAYE Plan. Some but not all of the savings in lower repayments that an old IBR enrollee might obtain by switching to the REPAYE Plan may be offset by a larger debt forgiveness tax liability obligation eventually imposed because of a larger amount of debt forgiven, although the amount of additional tax liability imposed will be limited by the more favorable REPAYE unpaid interest accrual provisions. If, on the other hand, an old IBR Plan enrollee has sufficient spousal income that their payments would be increased by switching to the REPAYE Plan, the preferable choice would be for that person to remain enrolled in the old IBR Plan, although the financial advantage of doing so would be reduced somewhat by the REPAYE Plan's more favorable unpaid interest accrual provisions. For detailed discussion of the tax liability aspects of the different Plans, see Crespi (2014), supra note 32.

90. As an illustration of this point, consider a 2016 old IBR Plan enrollee with a $\$ 75,000$ per year adjusted gross income, about the average income for a new law graduate that year, and a family size of three persons. That person will have a discretionary income of approximately $(\$ 75,000$ per year $-\$ 30,000$ per year $)=\$ 45,000$ per year, and will, therefore, 
Many law graduates have or will eventually have relatively welleducated spouses who will be working full-time for a number of years, and will, therefore, likely earn fairly substantial annual incomes that will approach or may even exceed $33 \%$ of the law graduate's annual income. As a result, many if not most of what I expect will be a relatively small (and rapidly shrinking) group of potential REPAYE Plan law graduate enrollees that are not eligible for the more generous PAYE Plan, and who have enrolled in the old IBR Plan, will pass upon the opportunity to change their enrollment to the new REPAYE Plan.

My conclusion here is that only a few law graduates at most will ever enroll in the REPAYE Plan, and the large majority of those few enrollees will be pre-2014 law graduates that are not eligible for PAYE Plan enrollment, that have expectations of at most small amounts of spousal income, and who will enroll in the REPAYE Plan shortly after July, 2016, when they are first eligible to do so.

As I have discussed, from 2016 onwards, a greater and greater proportion of each year's cohort of new law graduates, rapidly approaching $100 \%$, will be eligible for PAYE Plan enrollment, and they will, therefore, have no reason to even consider REPAYE Plan enrollment with its more stringent requirements. There are consequently likely to be extremely few, if any, REPAYE Plan law graduate enrollees after 2016, and therefore extremely few, if any, such enrollees qualifying for debt forgiveness in 2042 or afterwards. I will, therefore, in my subsequent illustrative tax liability calculations, for simplicity's sake, simply ignore the possibility of there being a small number of REPAYE Plan law graduate enrollees in 2017 or thereafter, and also ignore any potential tax liability borne in 2041 or thereafter by such enrollees.

under the old IBR Plan will have to make required monthly repayments of $((\$ 75,000$ $\$ 30,000) / 12$ ) x .15 $=\$ 563$ per month. Under the REPAYE Plan it would require a family discretionary income of $\$ 67,500$ year to have the same required monthly repayment obligation of $\$ 563$. $(\$ 67,500 / 12) \times .10=\$ 563$. Therefore, if the enrollee's spouse has an adjusted gross income of more than $\$ 22,500$ per year-more than $30 \%$ of the enrollee's $\$ 75,000$ per year adjusted gross income the REPAYE Plan will then be more costly than the old IBR Plan for that enrollee. If that 2016 old IBR Plan enrollee instead had an AGI of $\$ 100,000$ per year he would benefit from shifting to the REPAYE Plan unless his spouse had an AGI of more than $\$ 35,000,35 \%$ of the enrollee's AGI.

As a general rule of thumb, therefore, the spousal income cut-off line where shifting from the old IBR Plan to the REPAYE Plan is no longer to the enrollee's advantage is approximately $33 \%$ of the enrollee's AGI. I ignore in this calculation the possibility that an enrollee's family may bear some additional tax liability by having the enrollee and their spouse file separate tax returns rather than filing a single joint tax return and therefore possibly lose some deductions or credits or face less advantageous tax bracket cut-offs. 
It is, however, likely that some fraction of those law graduates who have enrolled in the old IBR program prior to 2016, and who do not expect to have significant spousal income over the coming decades, may elect to change their Plan enrollment during 2016 from the old IBR Plan to the REPAYE Plan in order to take advantage of the lower $10 \%$ of discretionary income monthly repayment requirement of the REPAYE Plan to reduce their monthly repayments - a reduction of as much as one-third if they have no spousal income at all. Those persons then will be making smaller repayments under this new Plan, and will consequently have somewhat larger amounts of debt remaining to forgive at the end of the twenty-fiveyear repayment period than they would have had they remained enrolled in the old IBR Plan; they will, therefore, have somewhat larger tax liabilities imposed upon them at that time. However, I do not expect this 2016 shift of old IBR Plan law graduate enrollees to the new REPAYE Plan to take place on a large enough scale, nor to impact the size of individual Plan enrollee required repayment amounts by a sufficient amount, ${ }^{91}$ for this to have significant individual or aggregate tax liability consequences. I will, therefore, also ignore this complication in my later illustrative calculations. If, however, the extent of Plan law graduate enrollees shifting from the old IBR Plan to the REPAYE Plan in 2016 is more significant in magnitude than I expect, or if the average increase in tax liability for those persons changing Plans is greater than I now estimate it will be, ${ }^{92}$ or both, my later calculations will, to that extent, underestimate the total tax liability imposed on Plan law graduates in $2041 .^{93}$ However, as I have noted, almost all such

91. Consider, for example, the relatively typical circumstances of a 2011 old IBR Plan enrollee with a $\$ 75,000$ adjusted gross annual income, and with a spouse and one child, and whose spouse has a only a $\$ 15,000$ adjusted gross annual income, only $20 \%$ of the enrollee's income. That enrollee would have to make monthly repayments starting at approximately $((\$ 75,000-\$ 30,000) / 12) \times .15=\$ 563$ per month under their Plan, but if they shifted in 2016 to the REPAYE Plan their initial monthly repayments would decline only modestly to $((\$ 75,000$ $+\$ 15,000-\$ 30,000) / 12) \times .10=\$ 500$ per month. This $\$ 63$ per month difference in required repayment amounts would, however, annually increase over the remaining twenty years of required repayments as both persons' incomes increased. Assuming 5\% annual income increases for both persons, they would now pay a total of approximately $\$ 63 \times(1.05)^{9} \times 20 \times$ $12=\$ 23,456$ less under the REPAYE Plan than under the old IBR Plan, and would therefore owe approximately an additional $\$ 23,456 \times .33=\$ 7,741$ in taxes on forgiven debt in 2041 , a fairly significant sum.

92. Id.

93. I have estimated that there were approximately 45,750 old IBR enrollees as of the first quarter of 2016. See supra note 80 . I do not know how many of those enrollees will have small enough expected spousal incomes over the coming two decades to justify their shifting to the REPAYE Plan to lower their required repayments, and consequently increasing their eventual debt forgiveness tax liability. I expect that there are not likely to be enough old IBR enrollees who will make this shift, nor will the individual tax consequences for those persons 
shifts from old IBR Plan enrollment to REPAYE Plan enrollment should take place in 2016, at the earliest opportunity for those persons to realize those repayment savings, and this shift, therefore, should have no impact on the amount of debt forgiveness tax liability in 2042, or thereafter.

Finally, starting in 2017, and especially in 2021 and thereafter, increasing numbers of law graduates each year will be eligible for enrollment in the new IBR Plan with its post-July 1, 2014 borrower requirement. ${ }^{94}$ That Plan has advantages over the old IBR Plan that are similar to those of the PAYE Plan, a low $10 \%$ of discretionary income repayment requirement and a short twenty-year required repayment period. However, all persons that are eligible for new IBR Plan enrollment will also be eligible for PAYE Plan enrollment, and the required repayments and repayment period under the new IBR Plan are identical to those of the PAYE Plan. In fact, the PAYE Plan is best viewed as simply being a 2012 administrative measure under the ICR Plan-creating statute that provided the same loan repayment terms to post-October 1,2007, new borrowers that later became available to post-July 1, 2014, new borrowers under the new IBR Plan statute. So whether a law graduate enrolls in the PAYE Plan or instead in the new IBR Plan will have no effect on the size or timing of their later debt forgiveness and consequent tax liability. I will, therefore, combine these two groups of Plan enrollees together for the purposes of my tax liability assessment, and will not attempt to separately analyze the individual or aggregate tax liability of enrollees in these latter two Plans.

Let me briefly summarize this extended discussion. From 2014 on, each year a larger and larger proportion of law graduates have met or will meet the eligibility requirements for PAYE Plan enrollment (or new IBR Plan enrollment after 2017). ${ }^{95}$ So, from 2014 onwards, the proportion of Plan law graduate enrollees who enroll in the old IBR Plan will gradually decrease to an insignificant figure as persons choose one of the more generous alternatives. The Plan enrollees qualifying for debt forgiveness in 2033 will all be 2013 PAYE Plan enrollees, but then in 2034 this will shift to them being mostly, but not exclusively, 2009 old IBR Plan enrollees. But then, in

be sufficiently large, to significantly affect my overall 2041 tax liability estimates that will be in the neighborhood of one billion dollars per year or more, and so I will simply ignore this complication. To the extent that a substantial number of old IBR enrollees do shift to the REPAYE Plan in 2016, and do thereby sharply increase their eventual tax liabilities, my overall tax liability estimates for 2041 will, therefore, be somewhat too low.

94. See 20 U.S.C. $\$ 1098 \mathrm{e}(\mathrm{b})(7)(\mathrm{B})$.

95. Compare 20 U.S.C. $\$ 1098 \mathrm{e}(\mathrm{b})(7)(\mathrm{B})$, with 34 C.F.R. $\$ 685.209(\mathrm{a})(6)$ (2016) (detailing how PAYE debt forgiveness and new IBR debt forgiveness are the same to the borrower). 
each following year from 2035 onwards, the Plan enrollees qualifying for debt forgiveness will increasingly be PAYE Plan (or new IBR Plan) enrollees rather than old IBR Plan enrollees. ${ }^{96}$

From 2041 onwards, there will also be debt forgiveness earned by some REPAYE Plan law graduate enrollees who have enrolled starting in July 2016, and who twenty-five years later will qualify for debt forgiveness, but this number is likely, even initially in 2041 , to be relatively small, and will certainly rapidly shrink further over time to a very small figure as potential REPAYE Plan enrollees increasingly qualify for the more advantageous PAYE Plan and new IBR Plan enrollment. Eventually, by about the mid2040s or so, virtually all Plan enrollees that qualify for debt forgiveness will be PAYE Plan (or new IBR Plan) enrollees that are subject to only $10 \%$ of discretionary income repayment requirements and twenty-year repayment periods, and who, as I will later demonstrate, are consequently likely to have substantial amounts of unpaid debt forgiven and large tax obligations imposed.

Now, exactly how rapidly the relative proportions of old IBR Plan enrollees and PAYE Plan enrollees who qualify for debt forgiveness starting in 2034 and afterwards will shift towards PAYE Plan (or new IBR Plan) enrollee dominance as the PAYE Plan's post-October 1, 2007, new borrower requirement becomes less constraining over time is a difficult question. Additionally, what proportion of that shrinking group of potential Plan law graduate enrollees who are not eligible for PAYE Plan enrollment will choose to change their enrollment from July 2016, onwards into the REPAYE Plan from the old IBR Plan, is another difficult question. There is, however, some quarterly aggregate DOE data available regarding the numbers of enrollees in the IBR and PAYE Plans from the start of the third quarter of 2013 through the start of the first quarter of $2016,{ }^{97}$ and this data strongly confirms the existence of the trend in relative Plan enrollments in favor of increased PAYE Plan enrollment that I have discussed above. ${ }^{98}$

Between the start of the third quarter and the start of the fourth quarter of 2013, the number of persons enrolled in the old IBR Plan increased by 130,000 , while the number of enrollees in the then newly-established PAYE

96. See FED. STUDENT AD, supra note 1.

97. NAT'L StUDENT LOAN DATA SYS., supra note 6. These DOE statistics are aggregate figures for all Plan enrollees and do not separate out law graduate enrollees from other enrollees. They do, however, suggest a trend of a relative increase in the proportion of PAYE Plan enrollments, based on increasingly broad PAYE Plan eligibility, a trend that is likely to hold for law graduate enrollees as well as for other enrollees.

98. Id. 
Plan increased by only 20,000 persons. ${ }^{99}$ Therefore, over that three-month time period approximately $87 \%$ of new Plan enrollees enrolled in the old IBR Plan and only $13 \%$ in the PAYE Plan. ${ }^{100}$ One year later, however, in the three months between the start of the third quarter and the start of the fourth quarter of 2014, the number of old IBR Plan enrollees increased by 200,000 while the number of PAYE Plan enrollees increased by $60,000,{ }^{101}$ so that over that three-month time period only $77 \%$ of the new Plan enrollees were old IBR Plan enrollees and the proportion of PAYE Plan enrollees had increased to $23 \%{ }^{102}$ And fifteen months later, in the three months that elapsed between the start of the fourth quarter of 2015 and the start of the first quarter of 2016, the number of IBR Plan enrollees grew by 220,000 while the number of PAYE Plan enrollees grew by $140,000,{ }^{103}$ so that the proportion of old IBR Plan enrollees among all new enrollees had declined to $61 \%$ with $39 \%$ of the new enrollees now being PAYE Plan enrollees. ${ }^{104}$ This accelerating growth in the relative proportion of Plan enrollees that elect to enroll in the PAYE Plan is consistent with my earlier analysis.

Based on the $10 \%$ increase (from 13\% to 23\%) in the proportion of Plan enrollees who were PAYE Plan enrollees, in a particular quarter over the year between mid-2013 and mid-2014, and on the additional 16\% increase in the proportion of PAYE enrollees in a particular quarter by the first quarter of 2016 (from 23\% to 39\%), I will, in my later illustrative calculations, conservatively assume that the proportion of PAYE Plan enrollees among all Plan law graduate enrollees will continue to grow after 2015 by an additional $10 \%$ each succeeding year, until, by 2022 , essentially all of the new Plan enrollees will choose the PAYE Plan (or the substantively identical new IBR Plan). ${ }^{105}$ I will, therefore, apply in my later illustrative calculations

\section{See id.}

100. $130,000 /(130,000+20,000)=.867 .20,000 /(130,000+20,000)=.133$.

101. See supra note 97.

102. $200,000 /(200,000+60,000)=.769 .60,000 /(200,000+60,000)=.231$.

103. See NAT'L STUDENT LOAN DATA SYS., supra note 6.

104. $220,000 /(220,000+140,000)=.611 .140,000 /(220,900+140,000)=.388$.

105. Given the recent acceleration in the relative rate of growth of PAYE Plan enrollment as compared to IBR Plan enrollment by the first quarter of 2016 , see supra note 97 , I regard this as a rather conservative projection as to the strength of the trend in Plan law graduate enrollment favoring utilization of the PAYE Plan. From 2014 onwards an increasingly smaller proportion of new law graduates will have taken out pre-October 1, 2007, student loans that would disqualify them from PAYE Plan enrollment. Many if not most 2014 and 2015 old IBR enrollees were probably eligible for the more generous PAYE Plan, but as a result of the confusing menu of federal repayment options that are available they were apparently not aware of this option, and therefore left "money on the table" by enrolling in the less generous but much better publicized old IBR Plan. Interview with Heather Jarvis, Student Loan Expert (July 10, 2015) (on file with the author). It is possible over the next few years we 
the following assumptions regarding the relative proportions of law graduate enrollees in the various Plans from 2009 onwards:

\begin{tabular}{|c|c|c|}
\hline Year(s) & Old IBR Plan Enrollees & PAYE Plan Enrollees \\
\hline $2009-2012$ & $100 \%$ & $\begin{array}{l}0 \% \text { (the PAYE Plan did } \\
\text { not exist prior to } \\
\text { December } 21,2012 \text { ) }\end{array}$ \\
\hline 2013 & $87 \%$ & $13 \%$ (DOE statistics) \\
\hline 2014 & $77 \%$ & $23 \%$ (DOE statistics) \\
\hline 2015 & $68 \%$ & $32 \%$ (DOE statistics) \\
\hline 2016 & (projected): $58 \%$ & $42 \%$ \\
\hline 2017 & (projected): $48 \%$ & $\begin{array}{l}52 \% \text { PAYE Plan (or } \\
\text { new IBR Plan) } \\
\text { enrollees }\end{array}$ \\
\hline 2018 & (projected): $38 \%$ & $\begin{array}{l}62 \% \text { PAYE Plan (or } \\
\text { new IBR Plan) } \\
\text { enrollees }\end{array}$ \\
\hline 2019 & (projected): $28 \%$ & $\begin{array}{l}72 \% \text { PAYE Plan (or } \\
\text { new IBR Plan) } \\
\text { enrollees }\end{array}$ \\
\hline 2020 & (projected): $18 \%$ & $\begin{array}{l}82 \% \text { PAYE Plan (or } \\
\text { new IBR Plan) } \\
\text { enrollees }\end{array}$ \\
\hline 2021 & (projected): $8 \%$ & $\begin{array}{l}\text { 92\% PAYE Plan (or } \\
\text { new IBR Plan) } \\
\text { enrollees }\end{array}$ \\
\hline 2022 and thereafter & (projected): $0 \%$ & $\begin{array}{l}\text { 100\% PAYE Plan (or } \\
\text { new IBR Plan) } \\
\text { enrollees }\end{array}$ \\
\hline
\end{tabular}

The law graduates enrolling in the old IBR Plan will have a twenty-fiveyear required repayment period before qualifying for debt forgiveness, ${ }^{106}$

may reach a "tipping point" where the level of awareness among law graduates of the generous PAYE Plan becomes so widespread that rather suddenly virtually all new law graduates will enroll in the PAYE Plan rather than in the old IBR Plan. If this does occur, then the relative proportion of PAYE Plan enrollees as compared to old IBR enrollees at that point increase more rapidly than my projections. As I will later demonstrate, PAYE Plan enrollees are likely to bear significantly larger debt forgiveness tax liabilities than are comparable old IBR enrollees, the total tax burden eventually imposed on those 2016 through 2022 Plan enrollees will be somewhat larger than my estimates.

106. See 20 U.S.C. $\$ 1098 \mathrm{e}(2)$. 
while the PAYE Plan and new IBR Plan enrollees will have only a twentyyear required repayment period. ${ }^{107}$ These different repayment period lengths complicate projecting the proportions of enrollees in each of the various Plans qualifying for debt forgiveness each year in 2033 onwards from the above initial Plan enrollment projections. When this complication is taken into account, which will lead each year to somewhat greater proportions of those Plan enrollees qualifying for debt forgiveness being PAYE Plan enrollees than otherwise would be the case, the enrollment estimates above lead to the following estimates for the relative proportions of enrollees in the various Plans who will qualify for debt forgiveness in 2033 and following years. I will apply these secondary estimates in my later illustrative calculations of aggregate law graduate debt forgiveness tax obligations: ${ }^{108}$

\begin{tabular}{|c|c|c|}
\hline Year(s) & $\begin{array}{l}\text { Old IBR Plan } \\
\text { Enrollees }\end{array}$ & $\begin{array}{l}\text { PAYE Plan } \\
\text { Enrollees }\end{array}$ \\
\hline 2033 & & $\begin{array}{l}100 \% \text { PAYE Plan } \\
\text { enrollees ( } 2013 \\
\text { enrollees) }\end{array}$ \\
\hline 2034 & $\begin{array}{l}75 \% \\
\text { enrollees })\end{array}$ & $\begin{array}{l}25 \%(2014 \\
\text { enrollees })\end{array}$ \\
\hline 2035 & $\begin{array}{ll}65 \% & (2010 \\
\text { enrollees })\end{array}$ & $\begin{array}{l}35 \%(2015 \\
\text { enrollees })\end{array}$ \\
\hline 2036 & $\begin{array}{l}55 \% \\
\text { enrollees })\end{array}$ & $\begin{array}{l}45 \%(2016 \\
\text { enrollees })\end{array}$ \\
\hline 2037 & $\begin{array}{l}45 \% \\
\text { enrollees })\end{array}$ & $\begin{array}{l}55 \%(2017 \\
\text { enrollees })\end{array}$ \\
\hline 2038 & $\begin{array}{ll}35 \% & (2013 \\
\text { enrollees })\end{array}$ & $\begin{array}{l}65 \%(2018 \\
\text { enrollees })\end{array}$ \\
\hline 2039 & $\begin{array}{l}25 \% \\
\text { enrollees })\end{array}$ & $\begin{array}{l}75 \%(2019 \\
\text { enrollees })\end{array}$ \\
\hline 2040 & $\begin{array}{l}15 \% \\
\text { enrollees })\end{array}$ & $\begin{array}{l}85 \%(2020 \\
\text { enrollees })\end{array}$ \\
\hline 2041 and thereafter: & $\begin{array}{l}5 \%(2016 \text { and later } \\
\text { enrollees) }\end{array}$ & $\begin{array}{l}95 \%(2021 \text { and later } \\
\text { enrollees) }\end{array}$ \\
\hline
\end{tabular}

107. See 34 C.F.R. $\S 685.209$ (a)(6).

108. If the shift in the relative proportions of new Plan enrollments between the old IBR Plan and the PAYE Plan moves toward PAYE Plan dominance more rapidly than I have here projected, see supra note 105 , then there will in general be a higher proportion of PAYE enrollees and a lower proportion of old IBR enrollees qualifying for debt forgiveness each year from 2036 onwards, increasing somewhat the aggregate amount of tax liability imposed beyond my estimates. 
C. The Average Debt Forgiveness Tax Obligation That Will be Imposed on Individual Old IBR and PAYE Plan Law Graduate Enrollees

The next step in determining the overall size of the tax bomb's impact on law graduates is to estimate how large the individual tax liabilities are likely to be for enrollees in the various Plans when their remaining debts are later forgiven. As I have discussed in Part IV.A. above, Plan law graduate enrollments are likely to be dominated by old IBR Plan and PAYE Plan enrollments, with the PAYE Plan over time increasingly becoming the preferred and eventually dominant Plan choice. I will, therefore, attempt to estimate the size of these tax liabilities only for enrollees in those two Plans.

The most important factors in determining the amount of debt forgiveness tax liability for a particular individual old IBR or PAYE Plan law graduate enrollee who will eventually qualify for debt forgiveness will be the following:

(1) how large their loan debt is at the time of their initial old IBR or PAYE Plan enrollment;

(2) the loan interest rates in force when they took out each of their undergraduate and law school student loans;

(3) the size of their adjusted gross income in each of the next twenty or twenty-five years after their Plan enrollment during which they will be required to make repayments;

(4) their family size each year during their repayment period;

(5) the marginal federal income tax rate applicable to their forgiven debt, based on the amount of their other taxable income and upon the tax rates then applicable for their filing status during the year of debt discharge; and

(6) the state income tax treatment that will be given to their forgiven debt in the year of debt discharge by their particular state of residence. ${ }^{109}$

Given the lack of disaggregated individual borrower data for old IBR or PAYE Plan enrollees, and the obvious impossibility of meaningfully projecting the future annual income levels or family size or state of residence for specific individual borrowers, it is feasible only to attempt to estimate an overall average tax liability for each of the two populations of old IBR Plan and PAYE Plan law graduate enrollees, respectively. This average tax liability per Plan law graduate enrollee in a particular year can be roughly calculated combining estimates made for each of the following

109. See generally I.R.S., DEP'T OF TREASURY, OMB NO. 1545-0074, FORM1040: U.S. INDIVIDUAL TAX RETURN (2005). 
determinative factors, based upon the earlier list of factors determining the tax liability for particular individual enrollees:

(1) the average debt load at the time of enrollment for all old IBR or PAYE Plan law graduate enrollees;

(2) the average loan interest rates across all of these enrollees and their loans;

(3) the average annual salary profile over the time period between Plan enrollment and debt forgiveness for this group of enrollees;

(4) the average family size profile for those enrollees over that time period; and

(5) the average marginal combined federal and state tax rate that will apply at the time of debt forgiveness to the forgiven debt for those enrollees.

Each of these averages will be difficult to precisely estimate with any real confidence, and, moreover, the calculation of an overall average tax liability per old IBR or PAYE Plan law graduate enrollee will multiplicatively compound the uncertainty inherent in each of these factor estimates. In order to advance the ball here, I will offer some detailed illustrative calculations regarding the size of the combined federal and state tax bill on this forgiven debt for hypothetical "average" old IBR and PAYE Plan law graduate enrollees, with these calculations based upon hopefully realistic simplifying assumptions with regard to each of the many abovenoted factors. These calculations can, of course, later be revised to be more accurate as better information becomes available. I will try to make very clear the specific assumptions that I will be making so that my methodology is transparent and such updating is facilitated.

There is fortunately some useful, though incomplete, statistical information available relating to the size of the average debt loads and future salary prospects of law graduates. Let me start by making some simplifying assumptions based on that information that will make these illustrative calculations more tractable. First, I will use 2014 as the year of Plan enrollment for each of these illustrative calculations. I will then assume that the law graduates who enrolled in the old IBR or PAYE Plans in 2014 had an average total graduate and undergraduate student loan debt combined of $\$ 160,000$ at the time they enrolled in their Plan, ${ }^{110}$ and that they will remain

110. Let me explain the basis for this assumption of $\$ 160,000$ average debt loads for 2014 IBR or PAYE law graduate enrollees. The average level of undergraduate debt incurred by persons who borrow to partially finance their undergraduate studies is approximately $\$ 30,000$. See Appel, supra note 22 . I will assume that law graduates who have borrowed to finance their law studies have on average also borrowed this $\$ 30,000$ amount to finance their undergraduate studies (although I concede that it is possible that law students are the beneficiaries of more generous parental contributions to the costs of their undergraduate 
enrolled until they qualify for debt forgiveness, and that they have an average family size of three persons throughout their required debt repayment period. ${ }^{111}$ I will also assume that the amount of federal student loan debt borne by those enrollees enrolling in 2015 or thereafter will increase by about 3\% per year annually from the assumed 2014 level of $\$ 160,000$ to reflect increases in annual tuition costs and the other costs of attending law school. ${ }^{112}$

studies than are other undergraduate borrowers). As for law school loans, the ABA has estimated the average amount borrowed by law students who took out loans to finance their 2012-2013 law school studies was $\$ 32,289$ for those attending public law schools, and $\$ 44,094$ for those attending private law schools. ABA, Anmual Questionnaire ABA Approved Annual Amount Borrowed: Fall 2013, (2013), http://www.americanbar.org/ content/dam/aba/administrative/legal education_and admissions to the bar/statistics/2013 f all_avg_amnt_brwd.xls [hereinafter $\overline{\mathrm{ABA}}, 2013$ Questionnaire]. $\overline{\mathrm{A}}$ simple, unweighted average of these public and private school amounts is $\$ 38,192$. This is actually a very conservative loan amount estimate because enrollments in private law schools in 2014-15 significantly exceeded enrollments in public law schools by a ratio of 76,282 to 41,802 . ABA, TASK FORCE ON THE FINANCING OF LEGAL EDUCATION, Report of the ABA Task Force on the Financing of Legal Education (2015) https://www. americanbar.org/content/dam/aba/administrative/legal_education_and_admissions_to_the_bar/ reports/2015_june_report_of the_aba_task_force_on_the_financing_of_legal_education.authc heckdam.pdf [hereinafter $\mathrm{A} \overline{\mathrm{B}} \mathrm{A}$, Task Force]. Multiplying this one-year average 2012-2013 law school loan amount estimate by three for the three years of law school from 2011-2012 through 2013-2014 gives an overall sum of \$114,576.

Now if the $\$ 114,576$ of law school loans is taken out on a regularly-spaced basis during the three years of law school then approximately an average of two years will elapse between the taking out of a loan and the borrower's later enrollment in the IBR or PAYE Plan, typically six months after law school graduation. At an assumed loan interest rate of approximately $6.44 \%$ per year, see infra note 127 , which accrues during law school and is added to the debt to be repaid even though the debt repayment obligations do not begin until six months after graduation, this will add another approximately $\$ 114,576 \times 0.1288=\$ 14,757$ to the average borrower's debt (I will not here consider the possible minor additional impact of accrued prePlan enrollment interest on the undergraduate loans of a later law graduate). Adding up these three debt balances $(\$ 30,000+\$ 114,576+\$ 14,757)$ yields a total average law graduate debt at the time of IBR or PAYE Plan enrollment in 2014 of $\$ 159,333$. For the sake of analytical convenience I will round this figure up slightly to $\$ 160,000$.

111. Given that some law graduates never marry, while others do marry and sometimes have one or more children, in the absence of more detailed information it appears reasonable for me to assume an average family size for law graduates over the twenty to twenty-five years following their IBR or PAYE Plan enrollment consists of three persons: the enrollee, their spouse and one child.

112. This $3 \%$ annual increase in the loan debts of post-2014 law graduate enrollees appears to me to be a relatively realistic assumption given recent comparable annual increases of this general magnitude or more in the law school tuition and living costs in recent years that these loans are taken out to cover, and this simplifying assumption will facilitate calculating the amount of debt forgiven by different cohorts of Plan enrollees as they later start their careers at higher average starting salaries and then later reach their debt forgiveness eligibility dates. It is possible that some law schools, in order to maintain their enrollments during a 
Estimating the average adjusted gross income of old IBR or PAYE Plan law graduate enrollees over their debt repayment period is difficult, but not impossible. First, recent National Association for Law Career Professionals ("NALP") statistics indicate that approximately two-thirds of the graduating law school class of 2013, by nine months after their graduation, had obtained full-time legal (or non-legal) positions lasting a year or more, and these positions paid an adjusted mean gross annual salary of $\$ 78,205 .^{113}$ But there are no available statistics that provide an adjusted mean annual starting salary for the remaining one-third of the 2013 graduating law school class who were, by nine months after their graduation, able to obtain only parttime legal (or non-legal) positions, or who remained unemployed at that time. Moreover, many of those unemployed persons or persons in part-time positions will have low incomes only temporarily and will eventually obtain better compensated full-time legal (or non-legal positions). ${ }^{114}$

In the absence of better data, I will assume for this illustrative analysis that two-thirds of each year's old IBR or PAYE Plan law graduate enrollees will earn starting salaries averaging the same as the NALP's \$78,205 annual salary for two-thirds of 2013 graduates, with that figure then adjusted upwards by $3 \%$ each year to reflect annual overall price and salary inflation for each graduating class in 2014 and thereafter. I will also assume that the remaining one-third of each year's old IBR or PAYE Plan enrollees will, by the time of their enrollment, have taken positions that on average pay starting salaries equal to the National Association of Colleges and Employers 2013 estimate of the average starting salary earned by persons with only undergraduate degrees of $\$ 44,928$ per year, again with that figure then also adjusted upwards annually by $3 \%$ to reflect my assumption as to annual overall price and salary inflation for each graduating class in 2014 and thereafter. ${ }^{115}$ This will lead to an overall estimated starting salary for

difficult period, may over the next few years increasingly discount their nominal tuition charge so that the actual annual increases in net tuition may be less than $3 \%$, but over the longer term an average increase in tuition and fees of at least $3 \%$ per year appears very likely.

113. NAT'L ASS'N FOR LAw PlaCEMENT, Class of 2013 Bimodal Salary Curve (July 2013), http://www.nalp.org/class_of_2013_bimodal_salary_curve [hereinafter NALP, 2013 Salary]. The mean salary determine $\bar{d}$ by NALP from its survey was adjusted downwards to correct for estimation errors stemming from differential responses rates to their survey among groups of persons with different income levels, with generally higher response rates for those persons with larger incomes. $I d$.

114. NAT'L ASS'N FOR LAW PLACEMENT, Top Salaries for First-Year Associate Remain Flat at \$160,000, But Prevalence Shrinks as Large Law Firm Market Becomes Less Homogenous (Oct. 9, 2014), http:/www.nalp.org/associate_salaries_2014 [hereinafter NALP, Top Salaries].

115. NAT'L AsS'N OF COLLs. \& EMPS., Salary Survey: Average Starting Salary for Class of 2013 Grads Increases 2.4 Percent (September 4, 2013), 
2014 old IBR or PAYE law graduate enrollees of $((\$ 78,205 \times .67)+$ $(\$ 44,928 \times .33)) \times 1.03=\$ 69,057$, with this estimated figure then increased by another 3\% each year from 2015 onwards for later Plan enrollees to reflect annual starting salary inflation. ${ }^{116}$

Having estimated the salary of these law graduate enrollees at the time of their 2014 old IBR or PAYE Plan enrollment, I will then assume for the purposes of my analysis that all of these enrollees will remain enrolled and will be steadily employed after their enrollment until they qualify for debt forgiveness, and that they will receive annual raises averaging $5 \%$ each year over this period, in an assumed stable macroeconomic environment with a $3 \%$ average annual rate of price inflation and consequent $3 \%$ annual increases in the poverty level income threshold used for determining the size of their repayment obligations. This is equivalent to assuming that law graduates will have their "real" incomes increase by $2 \%$ per year after their Plan enrollment until they later qualify for debt forgiveness.

This $2 \%$ per year real-salary-growth projection is a conservative but unfortunately probably realistic assumption for new law graduates for the coming two decades, given several structural changes in the legal profession in recent years which have together led to a significant and chronic shortage of well-paid entry-level attorney positions relative to the number of law graduates. ${ }^{117}$ This assumption is particularly important for my analysis since the rate of growth in a Plan enrollee's real income will determine the rate of growth of their discretionary income, which in turn will determine the rate of

http:/www.naceweb.org/s09042014/salary-survey-average-starting-class-2013.aspx [hereinafter Salary Survey].

116. Here are the starting salaries calculated in the manner discussed in the main text that I will utilize for IBR or PAYE required repayment calculations for law graduates from 2014 on for the following decade, increasing by $3 \%$ each year from the prior year's level: 2014 $\$ 69,057 ; 2015$ - $\$ 71,129 ; 2016$ - \$73,263; 2017 - \$25,461; 2018 - \$77,725; 2019 - \$80,056; 2020 - $\$ 82,458 ; 2021$ - $\$ 84,932 ; 2022$ - $\$ 87,480 ; 2023$ - $\$ 90,104$.

Given the limitations of the data that I am relying upon in making these average IBR or PAYE Plan law graduate enrollee starting salary projections I will not attempt to adjust these figures downwards to reflect the fact that law graduates with lower-than-average starting salaries are likely to enroll in IBR or PAYE Plans at somewhat higher rates than are law graduates with higher-than-average starting salaries. Nor will I attempt to estimate how much less the average adjusted gross income of Plan enrollees - which is the income amount that will be used for determining their monthly IBR or PAYE Plan repayment obligations-will be than their gross salary income, although it will surely be somewhat less than this amount for many enrollees due to $401(\mathrm{k})$ or 403 (b) retirement plan contributions and other exclusions from their gross incomes, thus reducing to some extent the size of their required repayment obligations.

117. See Judith Collins, Employment Rate for New Law School Graduates Rises by More Than Two Percentage Points, NAT'L ASS'N FOR LAW PLACEMENT (July 30, 2015), http//www.nalp.org/uploads/PressReleases/Classof2014SelectedFindingsPressRelease.pdf. 
growth of their debt repayments and in the eventual size of their remaining unpaid debt at the time of debt forgiveness.

Some other knowledgeable commentators are more optimistic than I am about the probable future salary trends for lawyers. ${ }^{118}$ Since there is clearly room for reasonable disagreement about the accuracy of such long-term projections, I will, after calculating my estimates of future individual and aggregate debt forgiveness tax liabilities for Plan enrollees under the $2 \%$ annual real salary growth assumption, also calculate how much those tax liability estimates would be reduced if one were to assume that there will be somewhat more rapid average annual rates of growth of $3 \%$ or even $4 \%$ in the real income of Plan law graduate enrollees after their enrollment.

Let me now turn to the calculation of the average annual interest rate on the outstanding debt for 2014 old IBR or PAYE Plan law graduate enrollees. An estimated $\$ 30,000$ of the average Plan enrollee debt of $\$ 160,000$ is undergraduate debt. ${ }^{119}$ The annual interest rate on federal undergraduate Stafford Loans in 2012 and 2013 was a fixed 3.4\%, but in mid-2013 that interest rate was changed to a new fixed rate for the duration of the loan. That new fixed rate that is then annually reset for subsequent new Stafford Loans in a manner that is indexed to remain $2.05 \%$ above the then-prevailing interest rate on ten-year Treasury bonds on July 1 of each year. ${ }^{120}$ As of July 1,2013 , that interest rate was initially set at $3.86 \%,{ }^{121}$ and on July 1,2014 , it was reset to $4.66 \%$; and then was again reset to $4.29 \%$ on July 1,2015 ; and to $3.76 \%$ on July $1,2016 .^{122}$ I will, therefore, utilize for these illustrative calculations a blanket annual interest rate of $4.00 \%$ for these undergraduate debts of old IBR or PAYE Plan enrollees that approximately reflects the average interest rate over recent years for undergraduate Stafford Loans.

118. Different analysts of law school affordability make different assumptions about future salary trends for lawyers and the future rates of overall price inflation. Herwig Schlunk, for example, assumed in his 2012 analysis that lawyer salaries would grow by $3.5 \%$ per year over the relevant future time period, and did not allow for any possible future price inflation, therefore implicitly assuming a relatively high real rate of growth of lawyer salaries of $3.5 \%$. Herwig Schlunk, Mamas 2011: Is a Law Degree a Good Investment Today?, 36 J. LEGAL PROF. 310 (2012). Michael Simkovic \& Frank McIntyre in their more recent work take the position that even Schlunk's 3.5\% estimate of annual real salary growth rates for typical lawyers is too low. Michael Simkovic \& Frank McIntyre, The Economic Value of a Law Degree, 43 J. LEGAL STUDIES 249, 260 (2014) ("Schlunk's analysis assumes an unrealistically low $3.5 \%$ real growth rate of earnings for law degree holders as they gain experience.").

119. See supra note 110.

120. 20 U.S.C. $\$ 1087 \mathrm{e}(\mathrm{b})(8)(\mathrm{A})(2012 \&$ Supp. 2016)

121. FED. STUDENT AID, What Are the Interest Rates on Federal Student Loans Dispersed Before July 1, 2015?, https://studentaid.ed.gov/sa/types/loans/interest-rates\#olderrates [hereinafter FED. STUDENT AID].

122. Id. 
For the remaining $\$ 130,000$ of average Plan law graduate enrollee debts that were incurred during law school, the average annual interest rate charged prior to mid-2013 was about $7.5 \%$, based on a mixture of Stafford Loans with $6.8 \%$ annual interest rates (for graduate student borrowers) and Grad PLUS loans with a much higher $7.9 \%$ annual interest rate. ${ }^{123}$ Since that date, however, the interest rate charged graduate and professional students on new Stafford Loans has also been annually indexed, set at 3.60\% above the interest rate on ten-year Treasury bonds for the life of the loans, and the rate for new Grad PLUS loans has been set at $4.60 \%$ above the ten-year Treasury bond rate, both interest rates being significantly higher premiums above ten-year Treasury bond rates than are charged for undergraduate loans. ${ }^{124}$ As of July 1, 2014, these loan rates were set at $6.21 \%$ for the Stafford Loans (later reset to $5.84 \%$ on July 1,2015 , and $5.31 \%$ on July 1 , 2016), and 7.21\% for the Grad PLUS loans (later reset on July 1, 2015, to $6.84 \%$ and to $6.31 \%$ on Ju1y 1,2016$).{ }^{125}$ I will, therefore, for these illustrative calculations utilize a blanket annual interest rate of $7.00 \%$ for the law school debts of IBR and PAYE Plan law graduate enrollees that approximately reflects the average interest rate in recent years imposed for a typical law graduate borrower's mix of Stafford and Grad Plus Loans. ${ }^{126}$

The overall "blended" loan interest rate that I will utilize for an "average" INR or PAYE Plan enrollee with $\$ 30,000$ of undergraduate debt and $\$ 130,000$ of law school debt will, therefore, be $6.44 \% .{ }^{127}$ As I will later demonstrate, after completing my illustrative tax liability calculations for hypothetical average PAYE Plan and old IBR Plan enrollees, these calculations are somewhat surprisingly only moderately sensitive to the interest rate charged borrowers.

The large amount of debt that will be forgiven under the current Code tax schedules will put most Plan law graduate enrollees into a relatively high marginal tax bracket, sometimes with some or all of that forgiven debt to be

123. See Crespi (2014), supra note 32, at 68 n.47.

124. Bipartisan Student Loan Certainty Act of 2013, Pub. L. No. 113-28, § 2(a)(3), 127 Stat. 506-07 (2013).

125. See FED. STUDENT AD, supra note 121

126. For these illustrative calculations I will ignore the possibility that a law graduate has financed a portion of his law school expenses with a Federal Perkins Loan, which carries an interest rate of $5 \%$. Id. Some law graduates may have done so up to the allowable Perkins Loan maximum of $\$ 8,000$ per year, thus lowering their overall average loan interest rate possibly to as low as $6.14 \%$ if they have incurred $\$ 24,000$ of Perkins Loans. Id. My later illustrative calculations of average Plan enrollee tax liability are, however, surprisingly robust with regard to relatively small differences in loan interest rates.

127. $((\$ 30,000 \times .04)+(\$ 130,000 \times .07)) / \$ 160,000)=\$ 10,300 / \$ 160,000=6.44 \%$. 
taxed at the $39.6 \%$ top marginal tax rate. ${ }^{128}$ Some states also impose relatively high top-bracket state income taxes on such cancellation of indebtedness income. ${ }^{129}$ I will, for these calculations, make the simplifying assumption that a $30 \%$ federal marginal income tax rate and a $3.3 \%$ marginal state income tax rate will each apply to this forgiven debt income for each of these two hypothetical average Plan enrollees, for an overall marginal tax rate of $33.3 \%$. 130

These several assumptions, when mathematically combined, will lead to my hypothetical average 2014 old IBR Plan and PAYE Plan law graduate enrollees initially each making monthly payments under their Plan that are not sufficient to even cover the interest accruing on their assumed initial $\$ 160,000$ debt. $^{131}$ There will, therefore, initially be negative amortization of their loan debts, they will grow rather than shrink over time. However, after some years of the assumed 5\% annual salary increases, these hypothetical enrollees' monthly repayments will eventually become large enough to cover all of their accruing loan interest, to begin to pay down the accumulated unpaid interest, and sometimes even some of the loan principal debt. But both the 2014 old IBR Plan enrollee and the 2014 PAYE Plan enrollee will each have a significant amount of remaining unpaid debt forgiven when they qualify for debt forgiveness, leading to substantial tax liability, with the amounts of debt forgiven and taxes owed by the hypothetical average PAYE Plan enrollee being substantially larger than the comparable amounts for the hypothetical average old IBR enrollee.

To illustrate this point (in perhaps excruciating mathematical detail), let me present illustrative calculations of the eventual debt forgiveness tax liabilities under my assumptions for each of these two hypothetical "average" 2014 Plan law graduate enrollees, one enrolling in the old IBR Plan and the other in the PAYE Plan. As I have noted, each of these enrollees will be assumed to remain enrolled in their Plan and will be regularly employed throughout the applicable twenty- or twenty-five-year repayment period, and each will be assumed to have a spouse and one dependent child over the entire repayment period.

128. See Crespi (2014), supra note 32, at 88 n.147.

129. Id. at $88-89$.

130. See id. at $88-91$.

131. The annual interest accruing on a $\$ 160,000$ loan debt at an assumed overall annual interest rate of $6.44 \%$ is $\$ 10,300$, or approximately $\$ 858$ per month. This is well in excess of the \$332 monthly repayments that an "average" 2014 PAYE Plan enrollee with a family of three persons will be required to make, and the $\$ 498$ monthly repayments that an "average" 2014 old IBR Plan enrollee with a family of three persons will be required to make. 
Let me first consider the circumstances of the hypothetical "average" law graduate enrolling in 2014 in the PAYE Plan. That enrollee, under my starting salary assumptions noted above, will have a 2014 annual starting salary of $\$ 69,057$. For analytical convenience, I will conservatively assume that this enrollee had no significant applicable deductions from gross income so that their adjusted gross income was the same $\$ 69,057.150 \%$ of the poverty level income for a family of 3 persons in 2014 was $\$ 29,295$. ${ }^{132}$ The monthly repayment obligations of this enrollee under the PAYE Plan will be $10 \%$ of the difference between the enrollee's adjusted gross income and $150 \%$ of the applicable poverty level income, and will, therefore, start at only $\$ 332$ per month. ${ }^{133}$ With the assumed $\$ 30,000$ of undergraduate debt of the enrollee's assumed total $\$ 160,000$ debt at the time of enrollment accruing interest at an assumed annual rate of $4 \%$, and the remaining $\$ 130,000$ law school portion of the debt accruing interest at an assumed annual rate of $7 \%$, for an overall blended interest rate of $6.44 \%,{ }^{134}$ this $\$ 332$ monthly payment will be far less than sufficient to cover the $\$ 858$ of monthly interest accruing on that debt, ${ }^{135}$ leading to negative amortization of the debt for that first year. However, under these 5\% annual salary growth and $3 \%$ inflation-linked annual increase of the poverty level wage assumptions, those initial $\$ 332$ monthly loan repayments will grow by approximately $6.5 \%$ per year in 2015 and thereafter as the enrollee's discretionary income increases at this rate. ${ }^{136}$ This $6.5 \%$ annual growth in the size of the repayments will have rather dramatic compounding effects over time, with the monthly repayments growing to about $\$ 1,098$ by the time of debt forgiveness in 2034 for 2014 PAYE Plan enrollees, ${ }^{137}$ and averaging about $\$ 585$ per month over the entire twenty-year required repayment period $^{138}$ before the enrollee becomes eligible for debt forgiveness.

132. Annual Update of the HHS Poverty Guidelines, 79 Fed. Reg. 3593 (Jan. 22, 2014).

133. $(\$ 69,057-\$ 29,295) \times 10 \%$ x $1 / 12=\$ 332$. IBRINFO, What's My Monthly Payment Plan?, http://www.ibrinfo.orgper monthly_payment.vp.html [hereinafter IBRINFO].

134. See supra note 127.

135. $((\$ 30,000 \times .04)+(\$ 130,000 \times .07))=\$ 10,300 . \$ 10,300 / 12=\$ 858$.

136. $((\$ 69,057 \times 1.05)-(\$ 29,295 \times 1.03)) /(\$ 69,057-\$ 29,295)=\$ 42,336 / \$ 39,762=$ 1.065 , a $6.5 \%$ annual increase in discretionary income.

137. $\$ 332 \times(1.065)^{19}=\$ 1,098$. These monthly repayments to be made in the 20 th and final year of required repayments are well below the approximately $\$ 1,811$ per month payments that would have to be made to repay a $\$ 160,000$ loan under standard ten-year repayment terms, so that this hypothetical average PAYE Plan enrollee will remain in a situation of "partial financial hardship" throughout his repayment period and therefore, there will not be any capping of repayment amount or capitalization of interest consequences ever imposed on that enrollee.

138. $\$ 332 \times(1.065)^{9}=\$ 585$ 
Under these assumptions, it will not be until approximately the seventeenth year of debt repayment that this hypothetical enrollee's monthly repayments under the PAYE Plan will have grown large enough to more than cover the $\$ 858$ per month of interest accruing on this $\$ 160,000 \mathrm{debt}^{139}$ Under the PAYE Plan rules, the government will accrue against the enrollee (but not capitalize into interest-bearing principal) all of the unpaid interest during the period of negative amortization. ${ }^{140}$ After sixteen years of negative amortization repayments, before the repayments have finally become large enough to cover the interest accruing on these loans, this enrollee will still owe all of the initial $\$ 160,000$ debt, and now will also owe a total of approximately $\$ 57,912$ of accrued and unpaid interest on this debt. ${ }^{141}$

139. For the sixteenth year of repayments, $\$ 332 \times(1.065)^{15}=\$ 854$, slightly less than $\$ 858$ but, for the seventeenth year of repayments, $\$ 332 \times(1.065)^{16}=\$ 909$, slightly larger than $\$ 858$.

140. This is assuming that none of the $\$ 30,000$ assumed undergraduate loan debt for this enrollee was in the form of subsidized Direct Loans for which the government would pay the accrued unpaid interest for the first three years after Plan enrollment.

141. This unpaid interest will accrue against the enrollee approximately as follows: In year one, this amount of accrued unpaid interest will be approximately ( $\$ 332 \times 12)-(\$ 858 \times$ $12))=\$ 6,312$. In year two, this amount of accrued unpaid interest will be approximately $((\$ 332 \times(1.065) \times 12)-(\$ 858 \times 12))=\$ 6,053$. In year three, this amount of accrued unpaid interest will be approximately $\left(\left(\$ 332 \times(1.065)^{2} \times 12\right)-(\$ 858 \times 12)\right)=\$ 5,777$. In year four, this amount of accrued unpaid interest will be approximately $\left(\left(\$ 332 \times(1.065)^{3} \times 12\right)-(\$ 858 \times\right.$ $12))=\$ 5,483$. In year five, this amount of accrued unpaid interest will be approximately $\left(\left(\$ 332 \times(1.065)^{4} \times 12\right)-(\$ 858 \times 12)\right)=\$ 5,170$. In year six, this amount of accrued unpaid interest will be approximately $\left(\left(\$ 332 \times(1.065)^{5} \times 12\right)-(\$ 858 \times 12)\right)=\$ 4,837$. In year seven, this amount of accrued unpaid interest will be approximately $\left(\left(\$ 332 \times(1.065)^{6} \times 12\right)-(\$ 858 \times\right.$ $12))=\$ 4,482$. In year eight, this amount of accrued unpaid interest will be approximately $\left(\left(\$ 332 \times(1.065)^{7} \times 12\right)-(\$ 858 \times 12)\right)=\$ 4,104$. In year nine, this amount of accrued unpaid interest will be approximately $\left(\left(\$ 332 \times(1.065)^{8} \times 12\right)-(\$ 858 \times 12)\right)=\$ 3,702$. In year ten, this amount of accrued unpaid interest will be approximately $\left(\left(\$ 332 \times(1.065)^{9} \times 12\right)-(\$ 858 \times\right.$ $12))=\$ 3,273$. In year eleven, this amount of accrued unpaid interest will be approximately $\left(\left(\$ 332 \times(1.065)^{10} \times 12\right)-(\$ 858 \times 12)\right)=\$ 2,817$. In year twelve, this amount of accrued unpaid interest will be approximately $\left(\left(\$ 332 \times(1.065)^{11} \times 12\right)-(\$ 858 \times 12)\right)=\$ 2,331$. In year thirteen, this amount of accrued unpaid interest will be approximately $\left(\left(\$ 332 \times(1.065)^{12} \times 12\right)\right.$ $-(\$ 858 \times 12))=\$ 1,813$. In year fourteen, this amount of accrued unpaid interest will be approximately $\left(\left(\$ 332 \times(1.065)^{13} \times 12\right)-(\$ 858 \times 12)\right)=\$ 1,262$. In year fifteen, this amount of accrued unpaid interest will be approximately $\left(\left(\$ 332 \times(1.065)^{14} \times 12\right)-(\$ 858 \times 12)\right)=\$ 675$. In year sixteen, this amount of accrued unpaid interest will be approximately $((\$ 332 \mathrm{x}$ $\left.\left.(1.065)^{15} \times 12\right)-(\$ 858 \times 12)\right)=\$ 50$. The total of accrued and unpaid interest after sixteen years of loan repayments will, therefore, be about $\$ 58,148$, which will be added to the original $\$ 160,000$ loan debt, but not capitalized into interest-earning principal.

By year seventeen, however, the monthly loan repayments payments will have grown to approximately $\$ 332 \times(1.065)^{16}=\$ 909$, now finally large enough to cover the monthly interest of $\$ 858$ accruing on the original $\$ 160,000$ debt and to also that year repay a small portion $(\$ 51$ x $12=\$ 612$ ) of the $\$ 58,148$ of accumulated unpaid accrued interest, leaving $\$ 55,978$ of that unpaid interest to be later repaid. In year eighteen, the amount of accrued unpaid interest that 
However, after four more years of monthly repayments continuing to grow in size at $6.5 \%$ per year, and now more than large enough to cover the $\$ 858$ monthly loan interest, approximately $\$ 6,792$ of that accrued and unpaid interest will have been repaid, leaving approximately $\$ 51,120$ of accrued and unpaid interest in 2034 when this enrollee now qualifies for debt forgiveness after twenty years of repayments. ${ }^{142}$ The amount of the enrollee's forgiven debt at that time will, therefore, be the original $\$ 160,000$ of unpaid loan principal plus the remaining $\$ 51,120$ of accrued and unpaid interest, for a total of $\$ 211,120 .{ }^{143}$ At the assumed applicable combined federal and state income tax rate of $33.3 \%$ this enrollee will owe taxes on this discharged debt of slightly over $\$ 70,000 .{ }^{144}$

The key conclusion here that has been reached rather laboriously can be very succinctly stated. A hypothetical 2014 PAYE Plan law graduate enrollee who has the average debt load at the time of enrollment of $\$ 160,000$, and who earns an average income for such a person thereafter and has an average family size, will have approximately $\$ 211,000$ of debt forgiven when they qualify for debt forgiveness in 2034, and will owe income taxes of about $\$ 70,000$ on this forgiven debt.

Let me emphasize again that these calculations are based upon several important underlying assumptions. The most important assumption is that of $5 \%$ average annual salary growth for this hypothetical average 2014 PAYE Plan enrollee after their enrollment, along with an assumption of a $3 \%$ annual rate of price inflation, together equivalent to an assumption of $2 \%$ annual growth in "real" income. ${ }^{145}$ My results are also based to a much more

will be repaid after covering the interest on the $\$ 160,000$ debt will be approximately $($ ( $\$ 332 \mathrm{x}$ $\left.\left.(1.065)^{17} \times 12\right)-(\$ 858 \times 12)\right)=\$ 1,325$, leaving $\$ 55,974$ of accrued interest to be repaid. In year nineteen the amount of accrued unpaid interest that will be repaid after covering the interest on the debt will be approximately $\left(\left(\$ 332 \times(1.065)^{18} \times 12\right)-(\$ 858 \times 12)\right)=\$ 2,080$, leaving $\$ 53,893$ of accrued interest to be repaid. Finally, in year twenty, this amount of repayment over and above the accruing debt interest will be approximately $\left(\left(\$ 332 \times(1.065)^{19}\right.\right.$ $x 12)-(\$ 858 \times 12))=\$ 2,881$, leaving $\$ 51,120$ of accrued interest to be repaid.

A total of about $\$ 6,792$ of the previously accrued unpaid interest will, therefore, be repaid during these last four years of repayments. At the time of debt forgiveness in 2034 this enrollee will, therefore, still owe the original $\$ 160,000$ of loan principal, plus an approximate additional amount of accrued and unpaid interest of $\$ 51,120$, for a total forgiven debt of approximately $\$ 211,120$.

142. Id.

143. $\$ 160,000+\$ 51,120=\$ 211,120$.

144. $\$ 211,120 \times .333=\$ 70,302.96$.

145. If one were instead to assume $6 \%$ average annual salary growth after Plan enrollment - equivalent to an assumption of a larger 3\% annual growth in real income-then this enrollee's discretionary income would grow by $8.2 \%$ per year rather than the previously calculated $6.5 \%$, see supra note 136 , and their average monthly payments over the twenty-year repayment period would then average $\$ 675$ rather than the previously calculated $\$ 585$, see 
modest extent upon my assumption of an overall $6.44 \%$ annual interest rate owed by the enrollee on their student loans. ${ }^{146}$

Let me now consider the somewhat different circumstances facing a hypothetical "average" 2014 old IBR Plan enrollee. That enrollee, under my salary assumptions, will again have a $\$ 69,057$ annual starting salary, but the monthly repayment obligations of this enrollee will now be $15 \%$ of the difference between the enrollee's family adjusted gross income and $150 \%$ of the applicable poverty level income, rather than $10 \%$ as for the PAYE Plan enrollee, and therefore will now be $\$ 497$ per month, ${ }^{147}$ rather than only $\$ 332$ per month. Even this larger $\$ 497$ monthly payment, however, will be insufficient to cover the $\$ 858$ of monthly interest accruing on this $\$ 160,000$ debt, ${ }^{148}$ also leading to negative amortization of the debt for that first year.

supra note 138. Over twenty years this more rapid payment growth would lead to a total increased debt repayment of approximately $(\$ 675$ - \$585) x 12 × $20=\$ 21,600$, reducing the amount of unpaid debt at the time of debt forgiveness for this average enrollee from $\$ 211,120$, see supra note 143 , to approximately $\$ 211,120-\$ 21,600=\$ 189,520$, and the debt forgiveness tax liability from $\$ 70,373$, see supra note 144 , down to $\$ 189,520 \times .333=\$ 63,110$, an $10.2 \%$ reduction in that tax liability.

If one were instead to assume a very optimistic $7 \%$ annual salary growth - equivalent to an assumption of a $4 \%$ annual growth in real income then this enrollee's discretionary income would grow by $9.9 \%$ per year rather than the previously calculated $6.5 \%$, see supra note 136 , and their average monthly payments over the twenty-year repayment period would then average $\$ 776$ rather than the previously calculated $\$ 585$, see supra note 138 . Over twenty years this more rapid payment growth would lead to a total increased debt repayment of approximately $(\$ 776-\$ 585) \times 12 \times 20=\$ 45,840$, reducing the amount of unpaid debt at the time of debt forgiveness for this average enrollee from $\$ 211,120$, see supra note 144 , to approximately $\$ 211,120-\$ 45,840=\$ 165,280$, and the debt forgiveness tax liability from $\$ 70,373$, see supra note 144 , down to $\$ 165,280 \times .333=\$ 55,038$, a $21.7 \%$ reduction in that tax liability. The average 2014 PAYE Plan enrollee would therefore still bear substantial debt forgiveness tax liability even under these much more optimistic assumptions about their average annual rate of real income growth after enrollment.

146. The annual interest rate owed by a PAYE Plan enrollee on their debt is somewhat surprisingly only a relatively minor factor in determining the size of their later debt forgiveness tax liability. For each $1 \%$ that the borrower's average overall annual loan interest rate differs from my assumed $6.44 \%$ rate, that borrower's interest charge on their assumed $\$ 160,000$ loan balance over the twenty-year PAYE Plan repayment period will differ only by $\$ 160,000 \times .01 \times 20=\$ 32,000$. For example, if a PAYE Plan enrollee had an overall loan interest rate of $5.94 \%$ on their loans $-0.5 \%$ below the assumed $6.44 \%$ annual rate used in my calculations - then they would have approximately $\$ 32,000 \times 0.5=\$ 16,000$ less in unpaid accrued interest at the time of debt forgiveness than the approximately $\$ 51,000$ that the hypothetical average 2014 PAYE Plan enrollee would still owe, and therefore would owe approximately $(\$ 210,000-\$ 16,000) \times .333=\$ 65,000$ in taxes, only about a $7.9 \%$ reduction in their tax liability from that of the hypothetical average PAYE Plan law graduate enrollee with a $6.44 \%$ annual loan interest rate.

147. $(\$ 69,057-\$ 29,295) \times 15 \% \times 1 / 12=\$ 497$.

148. $((\$ 30,000 \times .04)+(\$ 130,000 \times .07))=\$ 10,300 . \$ 10,300 / 12=\$ 858$. 
However, those initial $\$ 497$ monthly loan repayments under these 5\% annual salary growth and 3\% annual increase of the poverty level wage assumptions will again grow over time by approximately 6.5\% per year in 2015 and thereafter. $^{149}$ This $6.5 \%$ annual growth in the size of the repayments will once again have significant compounding effects over time, particularly now that the required repayment period is twenty-five years rather than twenty years. Given the substantially larger initial monthly repayments, these repayments will now grow to $\$ 1,811$ per month by the time of debt discharge in $2039,{ }^{150}$ and will average about $\$ 1,018$ per month over the twenty-five-year required repayment period. ${ }^{151}$ Unlike the situation of the hypothetical 2014 PAYE Plan enrollee, these average monthly repayments over the repayment period are now significantly larger than the $\$ 858$ monthly interest owed on the original $\$ 160,000 \mathrm{debt}$.

Under these assumptions, the old IBR Plan enrollee will also initially be making payments that are too small to cover the loan interest payments, again leading to negative amortization. Under the old IBR Plan, the government will again charge against the enrollee (but not capitalize into interest-bearing principal) all of the unpaid interest during the period of negative amortization. ${ }^{152}$ But by approximately the tenth year of loan repayments under the old IBR Plan, the 2014 enrollee's monthly payments will have grown large enough to now more than cover the $\$ 858$ per month of interest accruing on this initial $\$ 160,000$ debt. ${ }^{153}$ After nine years of negative amortization repayments, this average 2014 IBR Plan enrollee will,

149. See supra note 136.

150 . The initial monthly repayments of $\$ 497$ per month would grow to $\$ 2,252$ per month by the twenty-fifth year if it were not for the monthly payments cap of $\$ 1,811$ imposed on this hypothetical average old IBR enrollee, based on the monthly repayments imposed by a tenyear standard repayment schedule for a $\$ 160,000$ loan at a $6.44 \%$ interest rate. $\$ 497 \mathrm{x}$ $(1.065)^{24}=\$ 2,252$. But by the twenty-second year of repayments this cap will apply. $\$ 497 \mathrm{x}$ $(1.065)^{20}=\$ 1,751$, while $\$ 497 \times(1.065)^{21}=\$ 1,865$.

151. $\$ 497 \times(1.065)^{12}=\$ 1,058 . \$ 1,058$ is therefore the average monthly payment for uncapped payments for the entire twenty-five years of repayments. But if one also takes into account that the payments for the last four years will be capped at $\$ 1,811$ per month, this reduces the overall average monthly payment over the repayment period by about $\$ 40$ per month down to about $\$ 1,018$ per month.

152. This is assuming that none of the $\$ 30,000$ assumed undergraduate loan debt for this enrollee was in the form of subsidized Direct Loans for which the government would pay the accrued unpaid interest for the first three years after Plan enrollment.

153. For the ninth year of repayments, $\$ 497 \times(1.065)^{8}=\$ 822$, slightly less than $\$ 858$, but for the tenth year of repayments, $\$ 497 \times(1.065)^{9}=\$ 876$, slightly greater than $\$ 858$. 
therefore, still owe all of the initial $\$ 160,000$ debt, but now will also owe a total of approximately $\$ 22,696$ of additional accrued and unpaid interest. ${ }^{154}$

154. This unpaid interest will accrue against the enrollee approximately as follows: In year 1 this amount of accrued unpaid interest will be approximately $(\$ 497 \times 12)-(\$ 858 \times 12)$ $=\$ 4,332$. In year 2 this amount of accrued unpaid interest will be approximately $(\$ 497 \times 1.065$ $\mathrm{x} 12)-(\$ 858 \times 12))=\$ 3,944$. In year 3 this amount of accrued unpaid interest will be approximately $\left(\$ 497 \times(1.065)^{2} \times 12\right)-(\$ 858 \times 12)=\$ 3,531$. In year 4 this amount of accrued unpaid interest will be approximately $\left(\$ 497 \times(1.065)^{3} \times 12\right)-(\$ 858 \times 12)=\$ 3,092$. In year 5 this amount of accrued unpaid interest will be approximately $\left(\$ 497 \times(1.059)^{4} \times 12\right)-(\$ 858 \times$ $12)=\$ 2,624$. In year 6 this amount of accrued unpaid interest will be approximately ( $\$ 497 \mathrm{x}$ $\left.(1.065)^{5} \times 12\right)-(\$ 858 \times 12)=\$ 2,125$. In year 7 this amount of accrued unpaid interest will be approximately $\left(\$ 497 \times(1.065)^{6} \times 12\right)-(\$ 858 \times 12)=\$ 1,594$. In year 8 this amount of accrued unpaid interest will be approximately $\left(\$ 497 \times(1.065)^{7} \times 12\right)-(\$ 858 \times 12)=\$ 1,028$. In year 9 this amount of accrued unpaid interest will be approximately $\left(\$ 497 \times(1.065)^{8} \times 12\right)-(\$ 858 \times$ $12)=\$ 426$. The total of accrued and unpaid interest after 9 years of loan repayments will therefore be about $\$ 22,696$, and this amount will be added to the original $\$ 160,000$ loan debt, but not capitalized into interest-earning principal.

By year 10 , however, the monthly loan repayments payments will have grown to about $\$ 497 \times(1.065)^{9}=\$ 876$, now finally large enough to cover the monthly interest of $\$ 858$ accruing on the original $\$ 160,000$ debt and to also repay a small portion ( $\$ 18 \times 12=\$ 216)$ of the $\$ 22,696$ of accumulated unpaid accrued interest, leaving $\$ 22,480$ to be later repaid. In year 11 the amount of accrued unpaid interest that will be repaid after covering the interest on the debt will be approximately $\left(\$ 497 \times(1.065)^{10} \times 12\right)-(\$ 858 \times 12)=\$ 899$, leaving $\$ 21,581$ to be repaid. In year 12 the amount of accrued unpaid interest that will be repaid after covering the interest on the debt will be approximately $\left(\$ 497 \times(1.065)^{11} \times 12\right)-(\$ 858 \times 12)=\$ 1,627$, leaving $\$ 19,954$ to be repaid. In year 13 this amount of overpayment over and above the debt interest will be approximately $\left(\$ 497 \times(1.065)^{12} \times 12\right)-(\$ 858 \times 12)=\$ 2,402$, leaving $\$ 17,552$ to be repaid. In year 14 this amount of overpayment over and above the debt interest will be approximately $\left(\$ 497 \times(1.065)^{13} \times 12\right)-(\$ 858 \times 12)=\$ 3,227$, leaving $\$ 14,325$ to be repaid. In year 15 this amount of overpayment over and above the debt interest will be approximately $\left(\$ 497 \times(1.065)^{14} \times 12\right)-(\$ 858 \times 12)=\$ 4,106$, leaving $\$ 10,219$ to be repaid. In year 16 this amount of overpayment over and above the debt interest will be approximately ( $\$ 497 \mathrm{x}$ $\left.(1.065)^{15} \times 12\right)-(\$ 858 \times 12)=\$ 5,042$, leaving $\$ 5,177$ to be repaid. In year 17 this amount of overpayment over and above the debt interest will be approximately $\left(\$ 497 \times(1.065)^{16} \times 12\right)-$ $(\$ 858 \times 12)=\$ 6,039$. This sum will allow for payment of the remaining $\$ 5,177$ of unpaid accrued interest, and application of the remaining $\$ 862$ to the $\$ 160,000$ loan principal, reducing it to $\$ 159,138$.

Over the remaining eight years of loan repayments the outstanding debt will decline with increasing rapidity as the interest-bearing principal debt declines in the same manner as occurs in the amortization of a standard home mortgage loan. Let me detail this remainder of this process of debt reduction. In year 18 the repayments (now totaling $\left(\$ 497 \times(1.065)^{17} \times 12\right)=$ $\$ 17,397$ ) will be sufficient to pay the accruing interest and also reduce the outstanding loan principal by $\$ 7,101$ to $\$ 152,037$. In year 19 the repayments (now totaling $\left(\$ 497 \times(1.065)^{18} \mathrm{x}\right.$ $12)=\$ 18,528$ ) will be sufficient to pay the accruing interest and also reduce the outstanding loan principal by $\$ 8,744$ to approximately $\$ 143,293$. In year 20 the repayments (now totaling $\left.\$ 497 \times(1.065)^{19} \times 12=\$ 19,732\right)$ will be sufficient to pay the accruing interest and also reduce the outstanding loan principal by $\$ 10,511$ to approximately $\$ 132,782$. In year 21 the repayments (now totaling $\left.\$ 497 \times(1.065)^{20} \times 12=\$ 21,015\right)$ will be sufficient to pay the 
After eight more years of making monthly repayments that grow steadily in size at a rate of $6.5 \%$ per year, and now more than large enough to cover the $\$ 858$ monthly loan interest, that $\$ 22,696$ of accrued and unpaid interest will be fully repaid. ${ }^{155}$ The loan repayments over the final eight years of the twenty-five-year repayment period will now begin to reduce both the size of the loan debt and the annual interest charges on that shrinking debt in a fashion that parallels the workings of a typical home mortgage amortization schedule, leaving only approximately $\$ 59,000$ of unpaid debt at the time of debt forgiveness in $2039,{ }^{156}$ and an approximate tax liability of $\$ 20,000{ }^{157}$

This second laboriously reached conclusion can also be succinctly stated. A hypothetical 2014 old IBR Plan law graduate enrollee who has an average debt load at the time of enrollment of $\$ 160,000$, and who thereafter earns an average income for such a person and has an average family size, will have approximately $\$ 59,000$ of debt forgiven when they qualify for debt forgiveness in 2039 , and will owe income taxes of about $\$ 20,000$ on this forgiven debt.

These calculations are again based upon several important underlying assumptions, most importantly, my assumption of average annual salary growth for this hypothetical average 2014 old IBR Plan enrollee after their enrollment of $5 \%$, along with an assumption of a $3 \%$ annual rate of price inflation after Plan enrollment, equivalent to an assumption of $2 \%$ annual

accruing interest and also reduce the outstanding loan principal by $\$ 12,470$ to approximately $\$ 120,312$.

In year 22 the required repayments under the $15 \%$ of discretionary income formula will now total $\$ 497 \times(1.065)^{21} \times 12=\$ 22,380$, which slightly exceeds the $\$ 1,811 \times 12=\$ 21,732$ loss of "partial financial hardship" payment cap of the monthly amount needed to repay the initial $\$ 160,000,6.44 \%$ annual interest loan debt on standard 10-year terms, so that the latter sum of $\$ 21,732$ is all of the repayment that will be required of that enrollee in that year, which will be sufficient to pay the accruing interest and also reduce the outstanding loan principal by $\$ 13,990$ to approximately $\$ 106,322$. In year 23 the repayments (now again totaling $\$ 21,732$ under the cap) will be sufficient to pay the accruing interest and also to reduce the outstanding loan principal by $\$ 14,890$ to approximately $\$ 91,432$. In year 24 the repayments (now again totaling $\$ 21,732$ under the cap) will be sufficient to pay the accruing interest and also reduce the outstanding loan principal by $\$ 15,848$ to approximately $\$ 75,584$. And in year 25 the repayments (now again totaling $\$ 21,732$ under the cap) will be sufficient to pay the accruing interest and also reduce the outstanding loan principal at the time of debt forgiveness by $\$ 16,868$ to approximately $\$ 58,716$. I will henceforth in this article use an approximate figure of $\$ 59,000$ for this forgiven debt.

155. See supra note 154.

156. See supra note 154.

157. $\$ 58,716 \times .333=\$ 19,552$. I will henceforth in this article utilize an approximate figure of $\$ 20,000$ for this tax liability. 
growth in "real" income; ${ }^{158}$ also to a more modest extent upon my assumption of an overall $6.44 \%$ annual interest rate owed by the enrollee on their student loans. ${ }^{159}$

158. If one were instead to assume $6 \%$ annual salary growth-equivalent to an assumption of a larger 3\% annual growth in real income - then this enrollee's discretionary income would grow by $8.2 \%$ per year rather than the previously calculated $6.5 \%$, see supra note 136 , and their monthly payments over the twenty-five-year repayment period would then average $\$ 1,216$ rather than the previously calculated $\$ 1,018$ for the $2 \%$ annual real income growth rate assumption, see supra note 151 . The monthly repayments would have averaged a substantially larger $\$ 1,282$ per month over this repayment period if not for the imposition of the payment "cap" of $\$ 1,811$ per month, see supra note 150 , which will take effect under these salary growth assumptions in the eighteenth year of repayments.

Over twenty-five years, more rapid payment growth and larger payments for the first twentytwo years (before the payments under either assumption were capped at $\$ 1,811$ per month) would lead to a total increased debt repayment of approximately $(\$ 1,216-\$ 1,018) \times 12 \times 25=$ $\$ 59,400$, sufficient to eliminate the $\$ 58,716$ of unpaid debt under the prior $2 \%$ real income growth assumptions, see supra note 154 , for a hypothetical average 2014 old IBR enrollee who would qualify for debt forgiveness in 2039 . However, since the initial amount of debt owed at the time of enrollment and the income histories of different 2014 old IBR enrollees will each vary around these hypothetical average circumstances there will be some fraction of those enrollees, slightly over half of them if their financial circumstances follow the usual normal distribution, that would still owe some debt forgiveness taxes in 2039. But in most cases these would now be relatively small amounts of tax liability.

If one were instead to assume a very optimistic $7 \%$ annual salary growth-equivalent to an assumption of a 4\% annual growth in real income - then this hypothetical average 2014 old IBR Plan enrollee's discretionary income would grow by $9.9 \%$ per year rather than the previously calculated $6.5 \%$, see supra note 136 , and their average monthly payments over the twenty-five-year repayment period would then average $\$ 1,326$ rather than the previously calculated $\$ 1,058$, see supra note 151 . The monthly repayments would have averaged a substantially larger $\$ 1,546$ per month over this repayment period if not for the imposition of the payment "cap" of $\$ 1,811$ per month, see supra note 150 , which will take effect under these salary growth assumptions in only the fifteenth year of repayments. Over twenty-five years, more rapid payment growth and consequently larger payments for the first twenty-two years (before the payments under either assumption were capped at $\$ 1,811$ per month) would lead to a total increased debt repayment of approximately $(\$ 1,326-\$ 1,018) \times 12 \times 25=\$ 92,400$, well in excess of the $\$ 58,716$ of unpaid debt remaining after twenty-five years of repayments under the $2 \%$ real income growth assumption, allowing the debt to be fully repaid before the end of the twenty-five-year period. In other words, this more rapid payment growth under the assumption of $4 \%$ annual real income increases would surely be sufficient to discharge the debts of most if not virtually all 2014 old IBR enrollees before or by the end of their twentyfive-year required repayment period in 2039 , so that under that assumption there would be little if any tax liability imposed on any of these old IBR these enrollees.

The amount of debt forgiveness tax liability that old IBR enrollees are estimated to bear is thus shown to be quite sensitive to one's initial assumptions regarding the average annual rate of real growth in enrollee incomes after their enrollment, much more sensitive than are the amounts of tax liability that hypothetical average PAYE Plan enrollees are estimated to bear to those assumptions, see supra note 145 .

159. The annual interest rate owed by an old IBR Plan enrollee on their debt can be a fairly significant factor in determining the size of their later debt forgiveness tax liability. For 
The extensive calculations above have been carried out only for hypothetical "average" 2014 PAYE Plan and old IBR Plan enrollees. There will, of course, be substantial variation in the amount of debt that individual Plan law graduate enrollees will have at the time of their enrollment, and those Plan enrollees that have larger-than-average debt loads will consequently bear larger-than-average tax liabilities at the time of debt forgiveness, other things being equal.

For example, consider the circumstances of an otherwise average 2014 PAYE Plan law graduate enrollee who enrolls with a larger-than-average but not unimaginable initial $\$ 200,000$ debt, $\$ 40,000$ greater than that of the average law graduate enrollee. At the time of debt forgiveness, that enrollee will have an additional $\$ 40,000$ of unpaid principal plus an additional approximately $\$ 64,000$ of unpaid accrued interest, ${ }^{160}$ for a total forgiven debt of $\$ 315,000^{161}$ and an approximate tax liability of $\$ 105,000 .^{162} \mathrm{~A}$ comparable 2014 old IBR enrollee with a $\$ 200,000$ initial debt load would have $\$ 150,520^{163}$ of debt forgiven and an approximate tax liability of $\$ 51,000{ }^{164}$ Enrollees with average debt loads but with below-average incomes after enrollment and/or larger-than-average family sizes would similarly have larger-than-average amounts of debt forgiven and tax liabilities imposed.

In brief summary of these extensive calculations, if one assumes that no old IBR or PAYE law graduate enrollees will be so foolish or so unfortunate as to be dropped from their Plan for failure to make the required repayments, or for failure to file the required annual income verifications, then a hypothetical average 2014 PAYE Plan law graduate enrollee with an initial loan debt of $\$ 160,000$ at the time of enrollment and an average annual income thereafter will have accumulated an unpaid debt of about $\$ 211,000$ at the time of debt discharge twenty years after enrollment, and will owe

each $1 \%$ that the borrower's average overall annual loan interest rate differs from my assumed $6.44 \%$ that borrower's interest charge on their assumed $\$ 160,000$ loan balance over the twenty-five-year old IBR Plan repayment period will differ by $\$ 160,000 \times .01 \times 25=\$ 40,000$. So, for example, if an old IBR Plan enrollee had an overall loan interest rate of $5.94 \%$ on their loans $-0.5 \%$ below the assumed $6.44 \%$ annual rate used in my calculations - then they would have approximately $\$ 40,000 \times 0.5=\$ 20,000$ less in unpaid loan principal at the time of debt forgiveness than the $\$ 59,000$ of the hypothetical average 2014 old IBR Plan enrollee would owe, and therefore would owe only approximately $(\$ 59,000-\$ 20,000) \times .333=\$ 12,987$ in taxes, about a $35.1 \%$ reduction in their tax liability from the approximately $\$ 20,000$ owed by the hypothetical average old IBR Plan enrollee.

160. $\$ 40,000 \times .0644 \times 25=\$ 64,400$.

161. $\$ 211,120+\$ 40,000+\$ 64,400=\$ 315,520$.

162. $\$ 315,520 \times .333=\$ 105,068$.

163. $\$ 59,000+\$ 40,000+((\$ 40,000 \times .0644) \times 20)=\$ 150,520$.

164. $\$ 150,520 \times .333=\$ 51,123$. 
approximately $\$ 70,000$ in federal and state income taxes on this forgiven debt; those enrollees with larger-than-average debts and/or unfavorable later annual incomes after enrollment will end up owing upwards of perhaps $\$ 100,000$ or even more. However, a hypothetical average 2014 new IBR Plan enrollee with the same debt and later annual income characteristics will have an unpaid debt of only about $\$ 59,000$ at the time of debt discharge and will owe only approximately $\$ 20,000$ in federal and state income taxes on this forgiven debt, although, again, some old IBR Plan enrollees with unusually large initial debt loads and/or unfavorable later annual incomes could owe considerably more than this amount, perhaps even as much as $\$ 50,000$ or more. Some (but not all) of the substantial advantages of the PAYE Plan over the IBR Plan that are provided by the smaller required monthly repayments and the shorter required repayment period will, therefore, be offset by the larger (and also five years earlier) tax obligation imposed on PAYE Plan enrollees at the time of debt forgiveness.

Later post-2014 old IBR or PAYE Plan enrollees, while they will likely have somewhat larger loan debts at the time of their Plan enrollment as law school tuitions and living costs probably will continue to increase over time, under my inflation-based $3 \%$ annual growth in starting salaries assumption, ${ }^{165}$ will also be making comparably larger loan repayments each year during their twenty or twenty-five years of repayments than will the 2014 enrollees, because they will start from a somewhat larger annual income base. The higher repayments each year for these post-2014 enrollees should approximately offset their larger initial debt and consequently larger interest payment burden, leading to roughly the same general debt forgiveness and tax liability results for "average" post-2014 old IBR Plan and PAYE Plan enrollees as I have reached for 2014 enrollees. Similarly, old IBR Plan and PAYE Plan enrollees from 2009 through 2013 had, on average, somewhat smaller debt loads at the time of their enrollment than did the 2014 enrollees, but they also will have somewhat lower salaries on average in each year after their enrollment than will the 2014 enrollees, leading to the same general results for those earlier Plan enrollees as I have obtained for 2014 enrollees.

Having estimated in Part IV.B of this Article the relative proportions of Plan law graduate enrollees who will qualify for debt forgiveness in each of the different Plans in 2033 and thereafter, and having now estimated in this Part IV.C the amount of debt forgiveness tax liability that will be borne by

165. Which is a relatively conservative assumption given that annual increases in starting salaries for attorneys may reflect productivity improvements as well as price inflation, and thus may exceed somewhat inflation rates. 
average enrollees in the old IBR and PAYE Plans that have and will in the future dominate Plan enrollment, let me now turn to the difficult question of estimating how many Plan law graduate enrollees are likely to qualify for debt forgiveness each year in 2033 and thereafter so that the aggregate amount of tax liability imposed on those enrollees can then be estimated.

\section{The Number of Lawyers Who Will Receive Debt Forgiveness Each Year Under One or Another of the Plans}

I have unfortunately been unable to locate any statistics that classify IBR or PAYE Plan enrollees by their academic degrees that would enable one to precisely identify the relative proportions of current old IBR and PAYE Plan enrollees that are repaying law school loan debts (and often, also, undergraduate loans), as opposed to repaying other graduate or professional school loans or repaying only undergraduate loans. The DOE, however, has made available more aggregated summary statistics on a quarterly basis regarding the total number of enrollees in the IBR and PAYE Plans since early $2013,{ }^{166}$ and these statistics provide some basis for making inferences about past and future Plan law graduate enrollments. ${ }^{167}$

The earliest of these available DOE statistics show that a total of 950,000 persons were enrolled in either the old IBR Plan or the PAYE Plan

166. IBRINFO, supra note 133.

167. These DOE statistics aggregate together all IBR Plan and all PAYE Plan enrollees and unfortunately do not separate out law graduate enrollees. Nor do those statistics identify how many IBR and PAYE law graduate enrollees will later be taking advantage of the PSLF option and who will, therefore, receive debt forgiveness after ten years of qualified public service employment without bearing any debt forgiveness tax liability. It is, therefore, difficult to determine from these statistics the current situation and to make predictions as to future trends in the rate of enrollment by law graduates in the IBR Plan or the PAYE Plan who will not be choosing the PSLF option in the future, so as to be able to predict the number of Plan law graduate enrollees who will likely bear debt forgiveness tax liability twenty or twenty-five years later. In the absence of this data I will simply assume for these illustrative calculations that the proportion of IBR and PAYE Plan law graduate enrollees who will later utilize the PSLF option and will, therefore, not be subject to later tax liability is small enough that I need not attempt to adjust my predictions to reflect this complication.

To the extent that use of the PSLF option among law graduates becomes substantial, my predictions as to the rates of enrollment among law graduates in the IBR Plans or the PAYE Plan (but not later utilizing the PSLF option) may be correspondingly somewhat too large. The DOE may have more granular data available regarding the educational background and loan amount characteristics of law graduate and other borrowers at the time of their initial IBR or PAYE Plan enrollment, and as to the annual numbers of enrollees who will later be utilizing the PSLF option, but if so it has chosen not to make that data publicly available to outside commentators. 
as of the start of the third quarter of $2013 .{ }^{168}$ At that time, approximately $1.2 \%$ of undergraduate and graduate degrees conferred each year were threeyear law degrees, ${ }^{169}$ although with the decline in law school enrollments that has taken place in recent years and that will likely continue to some extent if not worsen over the next few years, this percentage will probably be closer to $1 \%$ in 2016 and thereafter. ${ }^{170}$ One could attempt to estimate the number of Plan law graduate enrollees as of that date on this basis alone by simply multiplying the number of Plan enrollees by the above percentage of degrees awarded that are three-year law degrees. However, the proportion of old IBR or PAYE Plan enrollees that are law graduates is, for several reasons, likely to significantly exceed this overall proportion.

First, a substantially higher proportion of law graduates than of persons earning only undergraduate degrees have taken out federal student loans, and one would expect this factor alone would lead to higher rates of enrollment in the Plans among law graduates than among holders of only undergraduate degrees. ${ }^{171}$ Second, and probably more importantly, the reduced monthly repayment benefits of Plan enrollment are much greater for high-debt law graduates than they are for other graduate and professional students; especially for undergraduate students, who generally incur far smaller loan debts. ${ }^{172}$ One would expect these substantially larger benefits that can be obtained from Plan enrollment to also lead to significantly higher Plan enrollment rates among law graduates than among other degree holders. In addition, one would expect law graduates to be more sophisticated than others, on average, regarding how to take advantage of favorable governmental programs.

My conjecture is that, for these several reasons, the proportion of Plan enrollees that are law graduates has always been and will continue to be at

168. Id.

169. See supra note 26.

170. As I will later discuss, law school enrollments have declined since 2012 and the number of annual law school graduates will likely stabilize at about 35,000 to 36,000 , roughly $1 \%$ of all degrees awarded each year.

171. Compare Brian Z. TAManaha, Failing Law Schools 120 (2012) (stating that approximately $88.6 \%$ of law graduates have outstanding student loans), with INST. FOR COLL. ACCESS \& SUCCESS, Quick Facts about Student Debt (Mar. 2014) (stating that only about 71\% of undergraduate borrowers have outstanding federal student loans). Due to this factor alone one would expect that the proportion of law graduates who became Plan enrollees would be $(88.6 \%-71 \%) / 71 \%=24.8 \%$ greater than the comparable proportion of undergraduate borrowers who enrolled in a Plan.

172. Crespi (2014), supra note 32, at 134 (citing Jason Delisle \& Alex Holt, Safety Net or Windfall: Examining Changes to Income-Based Repayment for Federal Student Loans, NEW AM. FOUND., 11-13 (Oct. 16, 2012), https://static.newamerica.org/attachments/2332-safetynet-or-windfall/NAF_Income_Based_Repayment.18c8a688f03c4c628b6063755ff5dbaa.pdf. 
least $25 \%$ higher than the overall proportion of law graduates among all eligible borrowers, if not more. I will, therefore, rather conservatively assume for all of my later calculations that for the 2009-2015 time period $1.5 \%$ of all Plan enrollees were law graduates, ${ }^{173}$ and that from 2016 onwards, $1.25 \%$ of all Plan enrollees will be law graduates. ${ }^{174}$

There were 1,320,000 persons enrolled in either the IBR Plan or the PAYE Plan as of the end of 2013 (2009 through 2013 old IBR Plan enrollees and 2013 PAYE Plan enrollees). ${ }^{175}$ I therefore estimate on this basis there were 19,800 Plan law graduate enrollees. ${ }^{176}$ Assuming, for analytical convenience, that there were equal numbers of old IBR Plan law graduate enrollments during each one-year period between July 1, 2009, and December $31,2013,{ }^{177}$ and given that essentially all of the 2013 PAYE Plan enrollees as of the end of 2013 had enrolled during 2013, this would lead to an estimate of 2,200 law graduates enrolling in the old IBR Plan during 2009, and 4,400 law graduates enrolling in the old IBR Plan during each year from 2010 through $2013,{ }^{178}$ and also 1,650 law graduates enrolling in the PAYE Plan in 2013. ${ }^{179}$

By the end of 2014, however, the combined enrollment in the old IBR and PAYE Plans had almost doubled to 2,480,000, a substantial increase of $1,160,000$ in the number of Plan enrollees over that year. ${ }^{180}$ There was rapid growth in IBR enrollments, ${ }^{181}$ and extremely rapid growth in PAYE enrollments, ${ }^{182}$ although there was no appreciable growth in participation in the earlier established and less generous Income-Contingent Repayment

173. $1.2 \% \times 1.25=1.5 \%$

174. $1 \% \times 1.25=1.25 \%$.

175. IBRINFO, supra note 133 adding the number of IBR recipients to the number of PAYE recipients at the end of Q1 of FY2014).

176. See NAT'L STUDENT LOAN DATA SYs., supra note 6 (adding the number of IBR recipients to the number of PAYE recipients at the end of Q1 of FY2014).

177. The actual number of old IBR Plan law graduate enrollments was probably a bit lower than this number in each of the earlier one-year periods, and a bit higher in each of the later years, and then probably declined somewhat in 2013 as the PAYE Plan first became available to some borrowers. But I will ignore these minor complications in my later calculations of old IBR Plan enrollments.

178. $19,800 / 4.5=4,400$ old IBR Plan law graduate enrollments during the second half of 2009 , and $2,200 \times 2=4,400$ old IBR Plan law graduate enrollments in each year from 2010 through 2013.

179. $110,000 \times .012 \times 1.25=1,650$.

180. IBRINFO, supra note 133 (adding the number of IBR recipients to the number of PAYE recipients at the end of Q1 of FY2014).

181. The number of IBR Plan enrollees increased by 860,000 during 2014 , a substantial $860,000 / 1,210,000=71.1 \%$ increase. $I d$.

182. The number of PAYE Plan enrollees increased by 300,000 during 2014, a huge $300,000 / 110,000=272.7 \%$ increase! $I d$. 
Plan. ${ }^{183}$ I estimate that the number of new Plan law graduate enrollees in 2014 among this large group of new Plan enrollees was $17,400,{ }^{184}$ a figure which is equal in size to $37.2 \%$ of that year's graduating law school class. ${ }^{185}$

By the beginning of the first quarter of 2016, the latest date for which DOE statistics are available, the combined enrollment in the IBR and PAYE Plans had again grown sharply to $3,960,000$ persons - an increase of another $1,480,000$ persons during $2015 .{ }^{186}$ There was again rapid growth in IBR enrollment $^{187}$ in 2015, and again extremely rapid growth in PAYE enrollment, ${ }^{188}$ although once again there was no appreciable growth in Income-Contingent Repayment Plan enrollment. ${ }^{189}$ Of those 1,480,000 new 2015 IBR or PAYE Plan enrollees an estimated 22,200 were law school graduates. ${ }^{190}$ This number is equal in size to a full $50.6 \%$ of the 2015 law school graduating class. ${ }^{191}$

On the basis of the above calculations that I have done using the DOE Plan enrollment statistics, I will for the purposes of my later illustrative calculations assume that in 2015 and thereafter the number of law graduates enrolling each year in a Plan, and then eventually qualifying for debt forgiveness twenty or twenty-five years later, will be approximately equal to $50 \%$ of the number of students graduating from law school in that year. It is quite possible that this enrollment rate assumption is too conservative, given, first, the acceleration in estimated Plan law graduate enrollment rates relative to the size of that year's graduating law school class from $37.2 \%$ in 2014 to $50.6 \%$ in 2015 ; second, that the Plan enrollment percentage among law graduates each year may well further increase significantly as the

183. The number of enrollees in the Income-Contingent Repayment Plan increased by only 20,000 during 2014 , only a $20,000 / 580,000=3.4 \%$ increase. Id.

184. $1,160,000 \times .012 \times 1.25=17,400$

185. There were 43,832 law school graduates in 2014. ABA, ABA Legal Education Section Releases Law Graduate Employment Data for Class of 2014 (Apr. 29, 2015), http:/www.americanbar.org/news/abaaban/aba-news-archives/2015/04/american_bar_ associa0.html. 17,400/43,832 $=0.3969$, or 39.7\% [hereinafter ABA, 2014 Law Graduate Data].

186. See NAT'L STUDENT LOAN DATA SYS., supra note 6 (adding together the number of recipients in the IBR Plan and the PAYE Plan for Q1 of FY 2016, then subtracting the number of recipients in the IBR Plan and the PAYE Plan for Q1 of FY2015).

187. Id.

188. Id.

189. Id

190. $1,480,000 \times .012 \times 1.25=22,200$.

191. There were 39,984 law school graduates in 2015. ABA, ABA Legal Education Section Releases Employment Data for Graduating Law Class of 2015 (May 3, 2016), http:/www.americanbar.org/news/abanews/aba-newsarchives/2016/05/aba_legal_education.html. 22,200/39,984 $=0.555,55.5 \%$. 
reduced repayment and debt forgiveness benefits of Plan enrollment and especially PAYE Plan enrollment become increasingly widely appreciated; and finally, as it becomes increasingly recognized that there is no potential downside risk at all to enrolling in the PAYE Plan. ${ }^{192}$ On the other hand, some unknown proportion of IBR and PAYE Plan law graduate enrollees will qualify for debt forgiveness (without tax liability) after ten years under the PSLF option, ${ }^{193}$ and those persons will, therefore, not be bearing debt forgiveness tax liability twenty or twenty-five years after their IBR or PAYE Plan enrollment.

Given these offsetting uncertainties, and the lack of better data, an assumption of $50 \%$ Plan enrollment for each graduating law school class in 2015 and thereafter appears reasonable. To the extent that the number of Plan enrollees each year who then remain in their Plan until qualifying for debt forgiveness diverges from being equal to $50 \%$ of the size of that year's graduating law school class, the aggregate tax liability that will be imposed on those Plan enrollees decades later will diverge from my estimates in the same direction and in the same proportion. ${ }^{194}$ This $50 \%$ enrollment estimate is of course based upon the assumption that no significant new legislative or regulatory restrictions will imposed on law graduate eligibility for Plan enrollment, or that make less (or more) attractive for law graduates the repayment requirements or debt forgiveness provisions of the Plans.

The next step here in the analysis is to estimate the number of law school graduates in 2015 and thereafter to which this estimated 50\% Plan enrollment figure can be applied. There were 46,776 law graduates awarded

192. John R. Brooks, Income-Driven Repayment and the Public Financing of Higher Education, 104 GEO. L.J. 229, 284 (2016) ("[T]here is little incentive not to enroll [in PAYE]; that it can be no worse than the ten-year [standard debt repayment] plan ensures that any wellinformed student should enroll in PAYE, even those who could afford to pay the costs of school] out of pocket.")

193. Persons participating in the PSLF option need not formally enroll in a Plan in advance, as is required for participation in the IBR and PAYE Plans, but must merely eventually submit evidence of qualifying employment for ten years. The first persons who will be eligible for debt forgiveness under the PSLF option will not become eligible until 2017 at the earliest, and there currently are no statistics publicly available indicating how many Plan law graduate enrollees will be using the tax-exempt PSLF debt forgiveness option rather than eventually obtaining taxable IBR or PAYE Plan debt forgiveness.

194. So, for example, if the number of Plan enrollees each year who then remain in the Plan until debt forgiveness turns out to be equal in size to $60 \%$ rather than $55.5 \%$ of that year's graduating law school class, an $8 \%$ increase in the number of enrollees over my estimate $(60 \% / 55.5 \%=1.08$, an $8 \%$ increase $)$, the aggregate debt forgiveness tax liability later imposed upon those enrollees will also be approximately $8 \%$ larger than estimated 
degrees in 2013; 43,832 in 2014; and 39,984 in $2015 .{ }^{195}$ The number of law graduates obtaining degrees in 2016 and in each year after will obviously depend upon the number of entering first-year law students three years earlier, and upon student attrition rates during law school. The number of entering first-year law students peaked at 52,488 in 2010-2011, and has been rapidly declining ever since. ${ }^{196}$ It is now down to 37,058 first-year students as of 2015-2016, ${ }^{197}$ and this number is widely expected to decline further by at least a modest amount before it stabilizes. I will base my subsequent calculations on the assumption that the number of entering firstyear law students each year will modestly fall further in 2016 to about 36,000 enrollees, and will stabilize at about 35,000 enrollees in 2017 and in succeeding years.

Historically, the number of law students receiving degrees in a given year is about $90 \%$ of the size of the entering cohort of first-year law students three years earlier. ${ }^{198} \mathrm{I}$ will, therefore, utilize in my subsequent calculations the following estimates regarding the number of new law graduates who will be potential enrollees for the IBR or PAYE Plans for each of the following years, starting in 2015 :

\begin{tabular}{|c|l|}
\hline \multicolumn{1}{|c|}{ Year } & \multicolumn{1}{|c|}{ Number of law graduates } \\
\hline 2015 & 39,984 law graduates ${ }^{199}$ \\
\hline 2016 & 35,707 law graduates ${ }^{200}$ \\
\hline 2017 & 34,132 law graduates ${ }^{201}$ \\
\hline
\end{tabular}

195. ABA, ABA Releases Class of 2013 Law Graduate Employment Data (Apr. 9, 2014), http://www.americanbar.org/news/abanews/aba-news-archives/2014/04/american_bar_associa 4.html [hereinafter ABA, Class of 2013 Data]; ABA, 2014 Law Graduate Data, supra note 185; ABA, 2015 Law Graduate Employment Data, http:/www.americanbar.org/content/dam/aba/administrative/legal_education_and_admissions _to_the_bar/reports/2015_law_graduate_employment_data.authcheckdam.pdf $\quad$ [hereinafter $\overline{\mathrm{ABA}}, 2 \overline{0} 15$ Law Graduate Data].

196. ABA, Enrollment and Degrees Awarded 1963-2012 Academic Years, http://www.americanbar.org/content/dam/aba/administrative/legal_education_and_admissions _to_the_bar/statistics/enrollment_degrees_awarded.authcheckdam.pdf.

197. ABA, 2015 Standard $50 \overline{9}$ Information Report Data Now Available, http:/www.americanbar.org/content/dam/aba/administrative/legal_education_and_admissions to_the_bar/governancedocuments/2015_fall_enrollment_announcement.autheheckdam.pdf.

198. ABA, infra note 200.

199. ABA, supra note 197.

200. ABA, ABA Section of Legal Education Reports 2014 Law School Enrollment Data (Dec. 16, 2014), $\quad \mathrm{http}: /$ www.americanbar.org/news/abanews/aba-newsarchives/2014/12/aba_section_of_legal.html (39,675 (2013 first year law students) $\mathrm{x} .90=$ $35,707)$.

201. Id. $(37,924$ (2014 first year law students) $\times .90=34,132)$. 


\begin{tabular}{|l|l|}
\hline 2018 & 33,352 law graduates \\
\hline 2019 & 32,400 law graduates \\
\hline 203 \\
\hline & 31,500 law graduates \\
\hline
\end{tabular}

Now applying my estimate that I have derived earlier from the DOE statistics that the number of Plan law graduate enrollees each year will be approximately equal to $50 \%$ of that year's law school graduating class for 2015 and thereafter, and using the estimates for Plan law graduate enrollment for 2009 through 2014 that I have derived earlier from those statistics, and using my projections above for the size of graduating law school classes in 2015 and thereafter, this results in the following estimates of the number of Plan law graduate enrollees from 2009 onwards:

\begin{tabular}{|l|l|}
\hline \multicolumn{1}{|c|}{ Year } & \multicolumn{1}{c|}{ Old IBR Enrollees } \\
\hline 2009 (all old IBR enrollees) & 2,200 enrollees \\
\hline 2010 (all old IBR enrollees) & 4,400 enrollees \\
\hline 2011 (all old IBR enrollees) & 4,400 enrollees \\
\hline 2012 (all old IBR enrollees) & 4,400 enrollees \\
\hline 2013 & $\begin{array}{l}6,050 \text { enrollees (4,400 old IBR } \\
\text { enrollees and 1,650 PAYE Plan } \\
\text { enrollees) }\end{array}$ \\
\hline 2014 & 17,400 enrollees \\
\hline 2015 & 19,992 enrollees \\
\hline 2016 & 17,854 enrollees \\
\hline 2017 & 17,066 enrollees \\
\hline
\end{tabular}

202. ABA, supra note 197 (37,058 (2015 first year law students) x .90 = 33,352).

203. 36,000 (estimated by me for 2016 first-year enrollment) x $.90=32,400$. If law school enrollments and the number of graduates annually start to increase again after 2019 , this would lead to correspondingly larger overall debt forgiveness tax liability in 2039 and thereafter once those increasing numbers of law graduates begin to qualify for debt forgiveness.

204. 35,000 (estimated by me for 2017 and later first-year enrollment) x $.90=31,500$.

205. See ABA, 2015 Law Graduate Data, supra note 195 (39,984 (2015 law graduates) x $.50=19,992)$.

206. $35,707 \times .50=17,854$. As I have discussed above, I am assuming for the purpose of these illustrative calculations that the number of Plan law graduate enrollees in 2016 and thereafter will not be affected by the fact that potential Plan enrollees who are not eligible for PAYE Plan or new IBR Plan enrollment will now have the additional option of enrolling in the REPAYE Plan.

207. $34,132 \times .50=17,066$. 


\begin{tabular}{|l|l|}
\hline \multicolumn{1}{|c|}{ Year } & \multicolumn{1}{c|}{ Old IBR Enrollees } \\
\hline 2018 & 16,676 enrollees $^{208}$ \\
\hline 2019 & 16,200 enrollees $^{209}$ \\
\hline 2020 and thereafter & 15,750 enrollees each year. $^{20}$ \\
\hline
\end{tabular}

If my estimates and projections here are accurate regarding the numbers of law graduates who enrolled in a Plan between 2009 and 2014, or who are likely to enroll in one Plan or another in 2015 or thereafter, this will mean that the tax bomb phenomena, which will start to impact a relatively small number of lawyers in 2033 when (most of) the earliest 2013 PAYE Plan enrollees complete their required repayment periods, will become more significant in the mid- to late-2030s, as each year, larger and larger numbers of IBR and PAYE Plan law graduate enrollees with substantial unpaid debt balances qualify for debt forgiveness, and as an increasing proportion of those qualifying Plan enrollees over time will be PAYE Plan (or new IBR Plan) enrollees with very large amounts of unpaid debt. This tax bomb question is therefore an important issue, but unfortunately one that has thus far been almost completely overlooked in the literature discussing the IBR and PAYE Plans. ${ }^{211}$

How many of these Plan law graduate enrollees will eventually qualify for debt forgiveness? The difficult problem of projecting the annual numbers of IBR and PAYE law graduate enrollees who will have their debts forgiven starting in 2033 is made even more challenging by recognition of the fact that surprisingly many persons who enroll in the IBR or PAYE Plans, and who benefit significantly from the reduced monthly repayments that are allowed by those Plans, are later dropped from the Plans as a result of failing to file the required annual income verifications that are necessary for loan servicers to determine their monthly repayment obligations, and then fail to promptly take the steps necessary for reinstatement. ${ }^{212}$ In addition, a substantial number of other IBR or PAYE Plan enrollees are dropped from

208. $33,352 \times .50=16,676$.

209. $32,400 \times .50=16,200$.

210. $31,500 \times .50=15,750$.

211. But see Crespi (2014), supra note 32, at 83-99 (including debt forgiveness tax liability in the analysis of loan repayment obligations of IBR and PAYE and PSLF Plan enrollees); Jonathan A. LaPlante, Congress's Tax Bomb: Income-Based Repayment And Disarming A Problem Facing Student Loan Borrowers, 100 CORNELL L. REV. 703, 732 (2015) (discussing the scale of student loans and a need for a solution); Ron Lieber, For Student Borrowers, Relief Now May Mean a Big Tax Bill Later, N.Y. TIMES, Dec. 14, 2012.

212. See Kelly Field, Thousands Fall Out of Income-Based Repayment Plans, CHRON. OF HIGHER EDU. (Apr. 2, 2015), http:/chronicle.com/article/Thousands-Fall-Out-of/229031/ (discussing the fallout of thousands from income-based repayment plans). 
the Plans because they default on their repayment obligations. ${ }^{213}$ However, given how generous the Plan benefits are for high-debt enrollees, and given the relatively high level of financial sophistication and understanding of administrative compliance procedures of law graduates, one would expect the rates at which law graduate enrollees are dropped from the IBR or PAYE Plans as a result of payment default or failure to supply the required annual income verification to be very low; much lower than for other enrollees who have generally lesser sophistication and much less at stake in remaining enrolled in their Plans.

But just how much lower these rates of enrollee attrition among law graduates are and will be in the future compared to the significant overall average attrition rates is unclear. ${ }^{214}$ The DOE has unfortunately not provided information that disaggregates the rate at which IBR and PAYE Plan enrollees are dropped from the Plans and not subsequently reinstated by the nature of their educational degrees, or by the size of their debt loads upon enrollment. For the purpose of my illustrative calculations, I will assume the rates of default among Plan law graduate enrollees are so vanishingly small that they can safely be ignored, and that all Plan law graduate enrollees will remain enrolled and in good standing under their Plan until they later qualify for debt forgiveness. ${ }^{215}$

Let me now combine the above estimates and projections that I have made as to the number of Plan law graduate enrollees each year from 2009 onwards with my earlier estimates presented in Part IV.B above as to the relative proportions of old IBR Plan and PAYE Plan enrollments among those law graduates qualifying for debt forgiveness each year starting in 2033, so as to project the number of law graduate enrollees under each of those two Plans who will qualify for debt forgiveness in 2033 , and in each following year:

213. Id. ("Over the course of a year long period from 2013 to 2014 , almost 700,000 borrowers who had enrolled in income-based plans -57 percent of the total-filed to failed to 'certify' their income by the deadline.").

214. Cf. Michael Simkovic, Financing a Legal Education, BRIAN LIETER's L. SCH. REP. 7 (Aug. 9, 2014), http://eiterlawschool.typepad.com/files/2014.08.02-financing-legaleducation-slides.pdf (estimating that the student loan two-year cohort default rate among law graduates is in the very low range of $1.4 \%$ to $1.7 \%$, well below the comparable $13.9 \%$ default rate for undergraduate borrowers, and $7.6 \%$ for Master's Degree, Doctoral Degree and professional school borrowers). Moreover, one would expect the rate of default among Plan law graduate enrollees to be lower than this already-low default rate among all law graduates given the generally lower monthly payment obligations required by these Plans as compared to the loan repayment obligations otherwise borne by borrowers.

215. See Simkovic, supra note 214 (assuming Simkovic's statistics remain constant). 


\begin{tabular}{|c|c|}
\hline Year & Number of Enrollees \\
\hline 2033 & 1,650 total enrollees (all PAYE Plan 2013 enrollees) \\
\hline 2034 & $\begin{array}{l}\text { 6,202 total enrollees, including 2,200 old IBR Plan } 2009 \\
\text { enrollees and 4,002 PAYE Plan } 2014 \text { enrollees }^{216}\end{array}$ \\
\hline 2035 & $\begin{array}{l}\text { 10,797 total enrollees, including } 4400 \text { old IBR Plan } 2010 \\
\text { enrollees and 6,397 PAYE Plan } 2015 \text { enrollees }^{217}\end{array}$ \\
\hline 2036 & $\begin{array}{l}\text { 11,899 total enrollees, including } 4400 \text { old IBR Plan } 2011 \\
\text { enrollees and } 7499 \text { PAYE Plan } 2016 \text { enrollees }^{218}\end{array}$ \\
\hline 2037 & $\begin{array}{l}\text { 13,274 total enrollees, including } 4400 \text { old IBR Plan } 2012 \\
\text { enrollees and 8,874 PAYE Plan } 2017 \text { enrollees }^{219}\end{array}$ \\
\hline 2038 & $\begin{array}{l}14,739 \text { total enrollees, including } 4400 \text { old IBR Plan } 2013 \\
\text { enrollees and 10,339 PAYE Plan } 2018 \text { enrollees }^{220}\end{array}$ \\
\hline 2039 & $\begin{array}{l}25,062 \text { total enrollees, including 13,398 old IBR Plan } \\
2014 \text { enrollees and 11,664 PAYE Plan } 2019 \text { enrollees }^{221}\end{array}$ \\
\hline 2040 & $\begin{array}{l}\text { 26,527 total enrollees, including 13,612 old IBR Plan } \\
2015 \text { enrollees and 12,915 PAYE Plan } 2020 \text { enrollees }\end{array}$ \\
\hline 2041 & $\begin{array}{l}24,845 \text { total enrollees, including } 10,355 \text { old IBR Plan } \\
2016 \text { enrollees and } 14,490 \text { PAYE Plan } 2021 \text { enrollees }\end{array}$ \\
\hline 2042 & $\begin{array}{l}23,942 \text { total enrollees, including } 8192 \text { old IBR Plan } 2017 \\
\text { enrollees and 15,750 PAYE Plan } 2022 \text { enrollees }\end{array}$ \\
\hline 2043 & $\begin{array}{l}21,906 \text { total enrollees, including } 6,156 \text { old IBR Plan } 2018 \\
\text { enrollees and 15,750 PAYE Plan } 2023 \text { enrollees } 225\end{array}$ \\
\hline 2044 & $\begin{array}{l}\text { 20,160 total enrollees, including 4,410 old IBR Plan } 2019 \\
\text { enrollees and 15,750 PAYE Plan } 2024 \text { enrollees }^{226}\end{array}$ \\
\hline 2045 & $\begin{array}{l}18,585 \text { total enrollees, including } 2,835 \text { old IBR Plan } 2020 \\
\text { enrollees and } 15,750 \text { PAYE Plan } 2025 \text { enrollees }\end{array}$ \\
\hline 2046 & $\begin{array}{l}\text { 17,010 total enrollees, including } 1,260 \text { old IBR Plan } 2021 \\
\text { enrollees and } 15,750 \text { PAYE Plan } 2026 \text { enrollees }^{228}\end{array}$ \\
\hline
\end{tabular}

216. $2,200+(17,400 \times .23)=6,202$.

217. $4,400+(19,992 \times .32)=10,797$.

218. $4,400+(17,854 \times .42)=11,899$.

219. $4,400+(17,066 \times .52)=13,274$.

220. $4,400+(17,066 \times .52)=13,274$.

221. $(17,400 \times .77)+(16,200 \times .72)=25,062$

222. $(20,017 \times .68)+(15,750 \times .82)=26,527$.

223. $(17,854 \times .58)+(15,750 \times .92)=24,845$.

224. $(17,066 \times .48)+15,750=23,942$.

225. $(16,200 \times .38)+15,750=21,906$.

226. $(15,750 \times .28)+15,750=20,160$.

227. $(15,750 \times .18)+15,750=18,585$.

228. $(15,750 \times .08)+15,750=17,010$. 


\begin{tabular}{|c|c|}
\hline Year & Number of Enrollees \\
\hline $\begin{array}{c}2047 \text { and } \\
\text { thereafter }\end{array}$ & 15,750 enrollees each year (all PAYE Plan enrollees) ${ }^{229}$ \\
\hline
\end{tabular}

With these estimates of the number of law graduate enrollees in each Plan that will qualify for debt forgiveness in each year starting in 2033 in hand, I am now finally (!) able to estimate the aggregate tax liability that will be imposed each year on these law graduates.

\section{E. The Overall Annual Debt Forgiveness Tax Liability Imposed on Lawyers}

Using the tax liabilities calculated in Part IV.B above for hypothetical average 2014 old IBR Plan and PAYE Plan enrollees of $\$ 21,000$ and $\$ 70,000$, respectively, and using the estimates calculated in Part IV.D above of the number of enrollees in each of these two Plans who will qualify for debt forgiveness each year, I reach the following annual aggregate debt forgiveness tax liability estimates for 2033 and thereafter:

\begin{tabular}{|l|l|}
\hline \multicolumn{1}{|c|}{ Year } & \multicolumn{1}{|c|}{ Debt Forgiveness Tax Liability Estimates } \\
\hline 2033 & $\$ 115.5$ million $^{230}$ \\
\hline 2034 & $\$ 324.1$ million $^{231}$ \\
\hline 2035 & $\$ 535.8$ million $^{232}$ \\
\hline 2036 & $\$ 612.9$ million $^{233}$ \\
\hline 2037 & $\$ 709.2$ million $^{234}$ \\
\hline 2038 & $\$ 813.7$ million $^{235}$ \\
\hline 2039 & $\$ 1,084.4$ million $^{236}$ \\
\hline 2040 & $\$ 1,176.3$ million $^{237}$ \\
\hline 2041 & $\$ 1,231.4$ million $^{238}$ \\
\hline
\end{tabular}

229. $(12,600 \times 0)+15,750=15,750$.

230. $(1,650 \times \$ 70,000=\$ 115,500,000$.

231. $(2,200 \times \$ 20,000)+(4,002 \times \$ 70,000)=\$ 324,140,000$.

232. $(4,400 \times \$ 20,000)+(6,397 \times \$ 70,000)=\$ 535,790,000$.

233. $(4,400 \times \$ 20,000)+(7,499 \times \$ 70,000)=\$ 612,930,000$.

234. $(4,400 \times \$ 20,000)+(8,874 \times \$ 70,000)=\$ 709,180,000$.

235. $(4,400 \times \$ 20,000)+(10,339 \times \$ 70,000)=\$ 813,730,000$.

236. $(13,398 \times \$ 20,000)+(11,664 \times \$ 70,000)=\$ 1,084,440,000$.

237. $(13,612 \times \$ 20,000)+(12,915 \times \$ 70,000)=\$ 1,176,290,000$.

238 . $(10,355 \times \$ 20,000)+(14,490 \times \$ 70,000)=\$ 1,231,400,000$. This figure assumes that there will be no increase in tax liability as a result of Plan law graduate enrollees shifting from old IBR Plan enrollment to REPAYE Plan enrollment in 2016 when the REPAYE Plan option first becomes available. To the extent that some Plan enrollees make this shift of Plans, 


\begin{tabular}{|l|l|}
\hline \multicolumn{1}{|c|}{ Year } & \multicolumn{1}{|c|}{ Debt Forgiveness Tax Liability Estimates } \\
\hline 2042 & $\$ 1,266.3$ million $^{239}$ \\
\hline 2043 & $\$ 1,225.6$ million $^{240}$ \\
\hline 2044 & $\$ 1,190.7$ million $^{24}$ \\
\hline 2045 & $\$ 1,159.2$ million $^{242}$ \\
\hline 2046 & $\$ 1,127.7$ million $^{243}$ \\
\hline 2047 and thereafter & $\$ 1,102.5$ million per year. $^{244}$ \\
\hline
\end{tabular}

I have finally reached my bottom-line tax liability projections; let me here succinctly summarize my results. The number of mid-career lawyers who will be subject to debt forgiveness tax liability under one or another of the Plans will steadily grow from slightly about 1,650 persons in 2033 , and about 6,200 persons in 2034 , up to over 26,500 persons by 2040 , and then will gradually decline to about 15,750 persons per year by 2047 and thereafter. ${ }^{245}$ The aggregate annual tax obligation borne by these groups of lawyers will rapidly grow from initially about $\$ 115$ million in 2033 to over $\$ 700$ million per year by 2037 , and then will steadily grow further to about $\$ 1.2$ billion per year from 2040 onwards. In the initial years, much of that tax liability will be imposed on old IBR Plan enrollees, in amounts averaging only about $\$ 20,000$, but over the years, a larger and larger proportion of that tax liability will be imposed each year upon PAYE Plan enrollees, in amounts averaging about $\$ 70,000$, and the overall tax payments will consequently grow substantially.

As I have discussed above, the size of these individual and aggregate annual tax liability estimates are sensitive in a linear fashion to the assumptions made regarding the annual rate of PAYE Plan and old IBR Plan

the overall tax liability imposed on those Plan enrollees when they later qualify for debt forgiveness in 2041 will be somewhat greater than this estimated amount, that change in overall tax liability depending in size on how many enrollees make the shift, and the size of resulting average impact upon their individual tax liabilities.

239. $(8,192 \times \$ 20,000)+(15,750 \times \$ 70,000)=\$ 1,266,340,000$.

240. $(6,156 \times \$ 20,000)+(15,750 \times \$ 70,000)=\$ 1,225,620,000$

241. $(4,410 \times \$ 20,000)+(15,750 \times \$ 70,000)=\$ 1,190,700,000$

242. $(2,835 \times \$ 20,000)+(15,750 \times \$ 70,000)=\$ 1,159,200,000$

243. $(1,260 \times \$ 20,000)+(15,750 \times \$ 70,000)=\$ 1,127,700,000$.

244. $(15,750 \times \$ 70,000)=\$ 1,102,500,000$.

245. As discussed above in the main text, I am assuming that there will not be any significant "jump" in the number of Plan enrollees qualifying for debt forgiveness in 2041 as a result of law graduate enrollments in the REPAYE Plan in 2016 when that Plan first becomes an available option, and most of those REPAYE Plan enrollments will be done by former old IBR Plan enrollees. If such a jump in enrollments occurs, then the gradual decline in Plan enrollments noted in the main text above will not begin until 2042 . 
law graduate enrollment in the coming years, which I have estimated will stabilize at approximately $50 \%$ of the size of each year's graduating law school class, ${ }^{246}$ and the overall annual tax revenues will consequently vary upwards or downwards from my estimates roughly in proportion to changes in that rate of enrollment. These tax liability estimates are also particularly sensitive to the assumptions made regarding the annual rate of growth in the real income of Plan enrollees after their enrollment. If one assumes that Plan enrollees will obtain average annual salary increases significantly larger than the $5 \%$ average annual increases that I have utilized for my estimates, then the amount of debt forgiven and tax liability borne by PAYE Plan enrollees and especially by old IBR Plan enrollees will be significantly reduced. ${ }^{247}$

Let me offer the reader who has been patient enough to follow my analysis this far two final reminders. First, those $\$ 20,000$ and $\$ 70,000$

246. See supra note 194 (using an estimated 50\% annual rate of Plan enrollment to calculate the aggregate debt forgiveness tax liability imposed upon enrollees in the event the actual annual rate of Plan enrollment is lower or higher than the estimated figure)

247. As I have previously discussed, my estimates for the tax liability borne by average PAYE Plan enrollees and especially old IBR Plan enrollees, are sensitive to my initial assumptions as to the rate of annual real income growth for these Plan enrollees after their enrollment. If one assumes a higher $6 \%$ average annual salary increase, and a consequent $3 \%$ annual rate of growth in real income, rather than the comparable $5 \% / 2 \%$ figures that I have used in the main text calculations, then the tax liability imposed on an average PAYE Plan enrollee will be reduced only by $11.2 \%$, see supra note 145 , but the tax liability imposed upon the average old IBR enrollee will be eliminated, although some old IBR enrollees will still bear some modest amounts of tax liability, see supra note 158 . The overall amount of tax liability imposed on Plan enrollees in each year will be correspondingly reduced, with the precise amount of reduction in a particular year depending on the mixture of PAYE Plan and old IBR Plan enrollees, with $6 \%$ average annual salary growth the aggregate tax liability imposed will be substantially less than what I have estimated. However, by 2043 and thereafter a much larger proportion of the Plan enrollees qualifying for debt forgiveness will be PAYE Plan enrollees, and even with $6 \%$ average annual salary growth the aggregate tax liability imposed will be almost $90 \%$ as much as what I have estimated.

If one assumes an even higher $7 \%$ average annual salary increases and a consequent $4 \%$ annual rate of growth in real income, then the tax liability imposed on an average PAYE Plan enrollee will still be reduced by only $21.7 \%$, see supra note 145 , but the tax liability that would have been imposed upon old IBR enrollees will now be eliminated altogether for virtually all of these enrollees, see supra note 158 . The overall amount of tax liability imposed on Plan enrollees in each year will again be correspondingly reduced, with the precise amount of reduction in a particular year again depending on the mixture of PAYE Plan and old IBR Plan enrollees qualifying for debt forgiveness in that year. Once again, in the first decade after 2033, when a larger proportion of the Plan enrollees qualifying for debt forgiveness are old IBR enrollees, with 7\% average annual salary growth the aggregate tax liability imposed will be substantially less than what I have estimated. However, by 2043 and thereafter a much larger proportion of the Plan enrollees qualifying for debt forgiveness will be PAYE Plan enrollees, and even with $7 \%$ average annual salary growth the aggregate tax liability imposed will be almost $80 \%$ as much as I have estimated. 
average tax liabilities that I have calculated for old IBR Plan and PAYE Plan enrollees, respectively, are just that - only averages. Some individual Plan enrollees will owe less and some will owe considerably more than these average amounts. Some PAYE Plan enrollees could even owe as much as $\$ 100,000$ or more in taxes, given a larger-than-average debt load at the time of Plan enrollment and/or an unfavorable later income experience. Second, these estimates are only made for Plan law graduate enrollees and do not include the debt forgiveness tax liabilities that may be borne by other Plan enrollees who have taken on relatively large debt burdens and/or who have an unfavorable later income experience. The magnitude of the tax bomb on all Plan enrollees will be larger, perhaps significantly so, than its impact on law graduates alone.

\section{F. The Effects of Inflation on the "Real" Burden Imposed on Lawyers by the Tax Bomb}

It should not be overlooked that the debt forgiveness tax liabilities that will be imposed on IBR and PAYE Plan enrollees in 2033 or thereafter will be paid in dollars that, due to price inflation over the intervening decades since their Plan enrollment, are likely to be of substantially less purchasing power than were the student loan dollars originally borrowed twenty or twenty-five years, or more, earlier. ${ }^{248}$ Under the assumption that I am utilizing annual price inflation rates of $3 \%$, the burden of a dollar of tax liability that is imposed on a taxpayer in 2033 or thereafter, due to cancellation of indebtedness, will be equivalent in "real" terms to only approximately $\$ 0.55$ of tax burden imposed twenty years earlier, ${ }^{249}$ and to only approximately $\$ 0.48$ of tax burden imposed twenty-five years earlier. ${ }^{250}$ Looked at in this way, the "real" burden of the tax bomb for IBR or PAYE Plan enrollees will only be approximately half as large as it would be were those tax obligations to be denominated in dollars of the same purchasing power as those borrowed in the underlying student loans. In a world of $3 \%$ annual price inflation, the taxes imposed on a certain amount of loan debt forgiven after twenty or twenty-five years will be only about half as burdensome as they would be in a world of stable prices. ${ }^{251}$ The likely

248. See generally U.S. DEP'T OF EDUC., FED. STUDENT AD, Income-Based Repayment, FINAD.ORG, http:/Www.finaid.org/loans/ibr.phtml (discussing the complexity of calculating the cost a loan in the IBR program due to inflation).

249. $1.03^{20}=1.806$, and $1 / 1.806=0.55$.

250. $1.03^{25}=2.094$, and $1 / 2.094=0.48$.

251. See generally Joel Mick, A Proposal for the Indexation of Debt for Inflation, $140 \mathrm{U}$. PA. L. REV. 2051 (1992) (considering the feasibility of indexing debt for inflation) 
persistence over the coming decades of modest annual inflation rates in the neighborhood of 3\% will, therefore, significantly reduce (by about half) the social impact of the debt forgiveness tax bomb for all IBR and PAYE Plan enrollees, law graduates as well as others.

That being said, however, even after accounting for inflation over the intervening decades this tax bomb will still have a substantial impact upon many attorneys, particularly those persons enrolled in the PAYE Plan. Even if the average 2014 PAYE Plan enrollee's tax obligation of \$70,000 in 2034 amounts to only $\$ 35,000$ when measured in dollars of 2014 purchasing power, given that twenty years after their law school graduation many attorneys will be trying to simultaneously make substantial home mortgage payments, save for their retirement, be paying or attempting to save for their children's college costs, and perhaps also providing or preparing to provide some financial support to aging parents, an additional and perhaps not fully anticipated \$70,000 tax obligation may well prove quite disruptive.

\section{Defusing the Tax Bomb}

There are a number of ways that the tax bomb problem could be avoided, or at least have its impacts upon Plan enrollees mitigated to some extent. One possible approach would be a legislative amendment to section 108 of the Internal Revenue Code, or new Treasury Department regulations pursuant to that Code section that would have a similar effect. Another approach would be legislative amendment of the statutes establishing the IBR and PAYE Plans. Finally, there could be changes made in the DOE administrative rules governing the PAYE Plan. Various measures along these lines will surely be proposed during the next decade-and-a-half before these tax obligations begin coming due in a substantial manner in 2033 .

I will first consider the arguments that can be offered for and against such measures as a matter of social policy, and will briefly offer my thoughts regarding the merits of these arguments. Second, assuming for the sake of argument that some measures to eliminate or at least mitigate the impacts of the tax bomb may be called for, I will then consider several possible actions that might be taken. Let me initially very briefly describe the main features of each of these possible actions, and I will then later discuss them in more detail.

The first proposal that I will consider is an amendment to section 108(f)(1) of the Code that would eliminate the tax bomb altogether for all Plan enrollees. The second proposal I will discuss is one or more of several possible new Treasury Department regulations relating to the interpretation of Code section 108. The third proposal that I will discuss is a very modest amendment to the Code that would leave the debt forgiveness tax liability 
rules in force, but which would allow Plan enrollees to pay these taxes over several years rather than requiring them to do so in the year in which the debt is forgiven, without undue penalty.

The fourth measure that I will discuss is a legislative amendment that would limit IBR and PAYE Plan eligibility to only the first $\$ 57,500$ or so of federal student loan debt. Finally, the last approach that I will consider is legislation and DOE administrative action that would together prospectively reimpose the original IBR requirement of monthly repayments of $15 \%$ of discretionary income for new enrollees in all of the Plans.

\section{A. Arguments For and Against Defusing the Tax Bomb}

There is a straightforward argument of a contract law nature that can be offered for leaving in place the current legal framework that will impose these debt forgiveness tax liability consequences on Plan enrollees, law graduates, and others, despite the substantial tax obligations that I have shown will be imposed on some of these enrollees. Let me briefly summarize that argument.

First, those Plan enrollees probably were at the time of their enrollment (or, for future enrollees, probably will be at the time of their future enrollment) aware of the Code's provisions regarding the tax treatment of cancellation of indebtedness income when they contractually agree to the terms of these Plans. If not, they should be charged with constructive notice of those legal provisions (certainly at least the Plan law graduate enrollees!). Those enrollees will benefit significantly for many years from the generous low monthly repayment terms of those Plans, and it is therefore entirely fair and appropriate to hold them to the somewhat less advantageous, but still relatively generous, debt forgiveness taxation aspects of the Plans. Enrollees who are granted not only generous monthly repayment terms which allow for significant negative amortization, but also substantial amounts of later debt forgiveness, should not in good conscience begrudge having to bear only the lesser amount of income taxes that are imposed on that forgiven debt that they have contractually agreed to, taxes that are also imposed by the Code on most other classes of debtors with forgiven debts.

In addition, as I have demonstrated, eliminating the tax bomb would create tax revenue losses of upwards of one billion dollars per year or more by 2039 even if one considers only the tax bomb impacts upon law graduates and not upon other Plan enrollees. This revenue shortfall would require either that substantial additional taxes be imposed on other taxpayers to make up for that lost revenue, or else would lead to a further increase of the federal financial deficit in those years, both unattractive alternatives. 
There is also a distributional equity argument that can be made against mitigating the tax bomb impacts, at least the impacts on Plan law graduate enrollees. The thousands of IBR or PAYE Plan law graduate enrollees who will qualify for debt forgiveness each year in 2033 and thereafter will be a group of mid-career lawyers who will, on average, have incomes at that time in their lives that are far in excess of the overall average national income. ${ }^{252}$ Conferring individual tax benefits of up to as much as $\$ 100,000$ or more upon such a narrow group of, on average, relatively affluent persons at the expense of the larger taxpaying public, is a distributionally regressive step that persons of an egalitarian persuasion might choose to oppose on that basis alone. Finally, given that the likely steady gradual price inflation over the decades after Plan enrollment will reduce the real burden of any debt forgiveness tax liabilities imposed decades later by perhaps about half, the more modest "real" magnitude of the tax bomb impacts on even the most affected PAYE Plan law graduate enrollees arguably does not justify any changes in the law other than perhaps allowing enrollees to pay these debt forgiveness tax obligations over several years without undue penalty.

In response to these plausible arguments for leaving the tax bomb aspects of the Plans in place, the advocates for mitigation measures can also offer a reasonably persuasive counter-argument, one based upon paternalistic principles rather than upon contractual premises and revenue implications. ${ }^{253}$ It has been shown beyond reasonable argument that people are often very poor long-term financial planners, as is demonstrated most clearly by the strikingly high proportion of employees who fail to contribute enough to their employers' $401(\mathrm{k})$ or 403(b) retirement plans even to obtain the employer matching contributions, ${ }^{254}$ in most instances, a virtual nobrainer financial decision. And, as this Article demonstrates, the calculation of the amount of debt forgiveness tax liability that a Plan enrollee will face decades later is a far more complicated undertaking than is ordinary retirement planning. It is simply not realistic to expect Plan enrollees to exhibit the extraordinary foresight and computational ability necessary to be able to determine how large their eventual debt forgiveness tax liability will

252. Compare U.S. BUREAU OF LAB STAT., Occupational Employment Statistics: 231011 Lawyers, http://www.bls.gov/oes/current/oes231011.htm (reporting that lawyers earned a mean wage of $\$ 136,260$ in 2015), with U.S. BUREAU OF LAB. STAT., Occupational Employment Statistics, http:/www.bls.gov/oes/current/oes_nat.htm $\# 00-0000$ (reporting that mean wage for all occupations was $\$ 48,320$ in 2015).

253. See e.g., VANGUARD, How America Saves: A Report on Vanguard 2014 Defined Contribution Plan Data (2015), https:/institutional.vanguard.com/iam/pdf/HAS 14.pdf (noting that during 2014 only $10 \%$ of their participants saved the statutory maximum dollar amount of $\$ 17,500(\$ 23,000$ for participants fifty and over)).

254. See id. 
be two or more decades later, and then to show the extreme self-discipline necessary to periodically set aside enough money in a conservative investment vehicle to eventually accumulate upwards of a hundred thousand dollars for a 2030's or 2040's tax eventuality. One need not embrace the more extreme arguments offered by some behavioral economists as to the pervasiveness and severity of departures from rationality to recognize that holding Plan law graduate enrollees to the often-overlooked or underappreciated debt forgiveness tax liability aspects of those complicated Plans will damage or even devastate the retirement finances of thousands of midcareer attorneys each year who have failed to make the necessary provisions to pay those taxes. ${ }^{255}$

Some additional non-paternalistic arguments can also be advanced in favor of reducing or eliminating the tax bomb impacts. The nominal interest rates charged by the federal government for student loans, and especially for graduate and professional student and law student loans, far exceed the costs to the federal government of obtaining the funding for such loans through the usual issuance of ten-year maturity Treasury bonds, which, as of May 17, 2016 , paid an annual return of only $1.81 \%{ }^{256}$ Even if one takes into account both the administrative costs to the government of making these student loans and the government's losses from a significant number of loan defaults, there is still such a large margin between the high nominal interest rates charged borrowers and the Treasury's very low funding costs that those loans will still, on balance, generate a substantial annual profit. ${ }^{257}$

This is particularly true for graduate and professional student loans which are made at significantly higher loan interest rates than are undergraduate loans, and where the rate of borrower default is much less than for undergraduate loans. Moreover, the default rates for law graduate borrowers are especially low, significantly lower than even the relatively

255. Layman, supra note 61 , at 155 (calling for exemption of debt forgiven under the IBR Plan from taxation to avoid having taxpayers subject to "massive tax liability in a single year').

256. BANKRATE, Treasury Securities, http:/www.bankrate.com/rates/interestrates/treasury.aspx.

257. There are disagreements regarding the proper discount rate to use to determine whether a program such as IBR generates a profit to the government or not. Some analysts argue for discounting expected governmental receipts by the governmental borrowing rate, which is required for some purposes under the Federal Credit Reform Act, 2 U.S.C. $\S 661 \mathrm{a}(5)(\mathrm{E})(2012)$. Others argue for use of what is called "fair value accounting" which uses higher market borrowing rates which arguably better reflect market risk. But there are also strong arguments that can be made against use of the fair-value approach, and it is not the dominant methodology. See, e.g., David Kamin, Risky Returns: Accounting for Risk in the Federal Budget, 88 IND. L.J. 723, 724 (2013). 
low default rates for all graduate and professional students. Even under the negative amortization loan repayments that many Plan law graduate and other graduate and professional school enrollees are permitted to make for a substantial portion of their required repayment period, the total amount of repayment from Plan enrollees will still result in a profit over and above the government's funding costs and other expenses for those loans. ${ }^{258}$ Given this fact, it no longer appears to be so unduly generous for the government to eventually forgive those unpaid student loan debts after twenty to twentyfive years of regular repayments without imposing a tax obligation on that forgiven debt. ${ }^{259}$ The distributional equity argument against providing tax relief to Plan enrollees at the expense of the general taxpayer public that I have noted above does not appear to be quite so persuasive once one realizes that those Plan law graduate enrollees, who would concededly benefit the most from any across-the-board student loan debt forgiveness tax relief measures, are exactly the persons who are arguably being overcharged the most on their federal student loans.

It should also be recognized that the government already allows debt forgiveness for some student loan debts without imposing tax liability under the PSLF option for those persons who work in a qualifying public service position for ten years. Moreover, many governmental positions that one would regard as primarily providing a "public service" only under an arguably unduly inclusive definition of that phrase qualify for the PSLF option. So why not also allow the student loan debt that is forgiven after a much longer twenty- or even twenty-five-year period of regular debt repayments under the Plans by persons who have engaged in a broader range of private sector occupations, many of which also have at least indirect beneficial effects for the larger public, to at least partially avoid taxation on this forgiven debt?

Finally, an argument can also be made that unlike many debts that are used to finance the acquisition of tangible property - and therefore, at least in some instances, provide the borrower with a tangible asset that can later be liquidated to pay a debt forgiveness tax bill-the educational "asset" that student loans finance is much less tangible and less easily converted to cash on short notice to pay debt forgiveness taxes, and that student loan debts merit more favorable tax treatment on that ability-to-pay basis alone. ${ }^{260}$

Often in tax policy, efficiency considerations are important, and sometimes even paramount. Almost everyone would agree that maintaining

258. Although this may not be the case if "fair-value accounting" methods are used to determine the discount rate to apply to those repayment receipts. See supra note 257.

259. Id.

260. Laplante, supra note 211 , at $712-14$. 
taxpayer incentives to act in a socially wealth-maximizing fashion is an important objective to be taken into account along with other policy goals. However, none of the measures that I will later propose as ways to address the tax bomb issue considered in this Article appear to raise significant efficiency concerns that would complicate the analysis of those measures. Let me explain.

Those persons who have already enrolled in one or another of the Plans are not, as a practical matter, likely to significantly change their saving or spending behavior during their subsequent long required repayment period on account of a reduction or even elimination of their debt forgiveness tax liability, a liability that will not affect them until about two decades or more later. ${ }^{261}$ It is true that at the later time of debt forgiveness a change in the tax liability rules that has been made years earlier to reduce or eliminate those taxes may have a significant impact on that year's tax liability for some enrollees. Such a change will lead the Plan enrollees thereby affected to use their increased after-tax income in that year of debt forgiveness for more spending and/or more saving in some proportions. Unless these aggregate spending and savings changes by these enrollees in that particular year are offset in the aggregate by the combined spending and savings reduction impacts of comparably higher taxes imposed on other taxpayers, there may be some rather modest (if even noticeable) macroeconomic impacts from the slightly increased government deficits. The nature of these impacts, however, will depend upon whether the economy is at a state of full employment at that time, or is instead at a state of underemployment and deficient aggregate demand, which of course is something that is impossible to accurately forecast two or more decades in advance. ${ }^{262}$ In addition, while one could argue that any reduction in debt forgiveness tax liability at the end of a Plan's repayment period would marginally increase the incentive of law students to take on larger loan debts, and thereby also indirectly reduce the pressure on law schools to limit future tuition increases, such a connection is very attenuated and likely to be extremely small in magnitude, and such further tuition increases perhaps may lead to better legal education rather than solely to possibly inefficient transfer payments. Overall, I think that any possible efficiency consequences of altering the current rules governing debt forgiveness tax liability will be minimal and can be safely ignored in addressing this tax bomb question.

261. See Alan J. Auerbach \& James R. Hines Jr., Taxation and Economic Efficiency 92 (Nat'l Bureau of Econ. Research, Working Paper No. 8181, 2001) (discussing the importance of analyzing the efficiency effects of tax policies).

262. In making this statement I am implicitly embracing a Keynesian view of the macroeconomic impacts of deficit financing, which not everyone accepts. 
So there is the controversy squarely presented. Given that these sharply conflicting arguments for and against mitigating the impacts of the tax bomb derive from very different initial premises, whether legislative or administrative measures should be taken to mitigate or even eliminate the tax bomb impacts upon law graduate Plan enrollees and other enrollees is clearly a question upon which reasonable persons can disagree. Probably everyone would agree that persons considering enrolling in the IBR or PAYE Plans should, at the least, be provided with clear and accurate information regarding the law governing debt forgiveness tax obligations, the likely magnitude of those taxes they will face given their initial debt loads, their salary, and other financial circumstances at the time of their enrollment, and the advantages of making provisions to set aside sufficient funds to pay these later tax obligations well in advance. But should we go further than merely providing prospective Plan enrollees with better information, and also more paternalistically change the law in some fashion that will later benefit these current and future Plan enrollees when their debts are forgiven?

I am personally ambivalent as to the proper resolution of this difficult question, but I have tentatively concluded that the law should not be changed, except for the adoption of a relatively minor amendment to the Code which would allow persons subject to tax liability for forgiven student loan debt to pay those taxes off over several years, rather than requiring them to pay all of those taxes in the year in which the debt is forgiven, without undue penalty. Given the strong contractual and distributional equity arguments noted above that can be made in favor of enforcing the current debt forgiveness tax obligations against Plan enrollees, I do not believe that that any further action is called for beyond allowing those Plan enrollees who face large debt forgiveness tax liabilities in 2033 or afterwards to pay those taxes over a several-year period.

However, obviously not all persons will agree with this conclusion, ${ }^{263}$ so let me proceed for the remainder of this Article under the assumption that some mitigating measures are called for beyond what I recommend, and I will offer several possible approaches for consideration.

263. See, e.g., Layman, supra note 61, at 156. Layman favors abolishing tax liability for debt forgiven under the IBR Plan, a position that I do not favor. 


\section{B. Measures to Reduce or Eliminate the Impact of the Tax Bomb upon Lawyers}

Let me present and discuss several possible measures to address the tax bomb problem, although, of course, other approaches to the problem are possible. First, I will consider the straightforward approach of a legislative amendment to section $108(f)(1)$ of the Code that would simply eliminate altogether the tax liability upon forgiven federal student loan debt for all current and future Plan enrollees. Second, I will consider some possible new Treasury Department regulations relating to section 108 , each of which would have a comparable impact as would such a legislative amendment, but which would not require Congressional approval.

I will then consider, as alternatives to legislatively or administratively eliminating the tax bomb altogether, each of several more limited measures that could be adopted, either alone or in combination, and that would each significantly reduce, although not eliminate, the impacts of the tax bomb. The first of these more limited alternative measures would be a modest legislative amendment to the Code that would simply allow those persons subject to substantial debt forgiveness tax liability, on the basis of forgiven student loan debts under one or another of these Plans, to pay those tax obligations over a period of several years, without undue penalty. Second, I will consider the possibility of legislation that would prospectively limit future eligibility for all of the Plans for both graduate and undergraduate borrowers to only include under the Plans the amount of federal loan debt that is allowed for independent undergraduate borrowers, currently $\$ 57,500$, leaving borrowers to repay any other student loan debt they may have outside of those Plans. Such legislation would prevent virtually all law graduates and other high-debt borrowers from in the future putting themselves into a position under the old IBR Plan, and especially under the new IBR or PAYE Plans, where they might later bear very large tax liability for forgiven debt. Finally, I will consider the combination of legislation and DOE administrative action that would together impose upon all the Plans the original IBR requirement of minimum monthly repayments of $15 \%$ of disposable income for all future Plan enrollees, rather than the current $10 \%$ requirement now allowed under some of those Plans. Such action would significantly reduce the debt forgiveness tax liability for most new IBR Plan and PAYE Plan law graduate enrollees. 


\section{Amendment of the Internal Revenue Code to Eliminate Taxation of Debt Forgiven under the IBR or PAYE Plans}

Consider an amendment to Code section 108(f)(1) that would supplement it in the following manner (the added language is italicized and within brackets):

In the case of an individual, gross income does not include any amount which (but for this subsection) would be includible in gross income by reason of the discharge (in whole or in part) of any student loan if such discharge was pursuant to a provision of such loan under which all or part of the indebtedness of the individual would be discharged if the individual worked for a certain period of time in certain professions for any of a broad class of employers, [or if such discharge was pursuant to a provision of any federal income-based or income-contingent loan repayment program].

One could perhaps use somewhat more technical language than I have proposed above to more clearly delimit the new classes of loan debts exempt from taxation. ${ }^{264}$ This simple amendment would eliminate the student loan debt forgiveness tax obligations of all current and future Plan enrollees; problem solved. However, there would, for the reasons that I have discussed above, likely be substantial political opposition raised to any substantial legislative reduction in the debt forgiveness tax liability of both existing and future Plan enrollees, and certainly to the complete abolishment of such tax liability. As noted above, I do not favor such drastic action. And absent a strong public consensus expressed in its favor, such a proposal is unlikely to garner sufficiently broad political support to survive the currently highly polarized and gridlocked Congressional process, particularly with regard to taxation matters, and then obtain Presidential approval.

I have noted in Part V.A above several reasons why it would probably be impossible to obtain a sufficiently broad consensus to legislatively abolish debt forgiveness tax liability for debt discharged under the Plans. There are the strong contractual arguments noted above for holding Plan enrollees to the terms of their Plans. In addition, there is the cost of the lost tax revenues that such an amendment would entail, which, as I have demonstrated, will probably be on the order of one billion dollars per year or

264. See, e.g., Layman, supra note 61, at 156 (suggesting the following language: "or (B) such discharge was pursuant to Subsections (d)(1)(D) and (e)(7) of Section 455, or Section 493 $(\mathrm{C})(\mathrm{B})(7)$, of the Higher Education Act of 1965 (relating to income contingent and income based repayment respectively)"). 
more each year from 2039 onwards just for the Plan law graduate enrollees alone. Moreover, the revenue losses would be larger than these amounts, perhaps significantly so, when all of the other Plan enrollees who will qualify for debt forgiveness are also considered. Whether it was proposed that these tax benefits be conferred as part of a broader and revenue-neutral set of amendment to the Code therefore provided at the expense of correspondingly higher taxes imposed upon other taxpayers - or were to be conferred in isolation and therefore resulting in a comparable increase in the size of the annual government deficit, ${ }^{265}$ such a proposal will obviously lead to contentious political debates.

Second, amending the Code to eliminate this student loan debt forgiveness tax liability would have distributional implications that many persons on either side of the Congressional aisles would oppose, particularly those of an egalitarian bent. Such a change would have very concentrated benefits. It would provide individually large tax savings of $\$ 50,000$ up to perhaps $\$ 100,000$ or more to a rather small group of relatively affluent PAYE Plan enrollee mid-career lawyers; tax savings of perhaps $\$ 15,000$ up to about $\$ 25,000$ or more to another small group of relatively affluent old IBR Plan enrollee mid-career lawyers; and smaller but still in some instances significant tax savings of several thousand dollars or more for a somewhat larger group of other relatively affluent Plan enrollees with medical or graduate school training, or at least undergraduate educations. This measure would therefore, on balance, have decidedly regressive distributional effects, given that its benefits would be granted at the expense of correspondingly higher taxes imposed upon the broad spectrum of other taxpayers, or at the expense of a comparable increase in the size of the annual government deficits, although, as I have noted, one could argue that such benefits merely serve to undo the overcharging of those particular Plan enrollees, with their very low loan default rates, that has taken place through the unduly high loan interest rates charged to those classes of borrowers that do not properly reflect those low default rates.

A legislative amendment to the Code that would eliminate the tax bomb altogether is unlikely to even emerge from House or Senate Congressional committee hearings, in my opinion, let alone be adopted into law, even if the 2016 election as appears likely results in the election of Hillary Clinton as President and in Democratic control of the Senate. ${ }^{266}$

265. This is under the assumption that abolishing debt forgiveness tax liability would not have any significant short-term macroeconomic stimulus effects that would increase overall national income and therefore generate some additional offsetting new tax revenues.

266. I note in passing that such a legislative proposal would not provide any tax benefits until 2033 and later and therefore, would not have revenue consequences within the first 10 
2. New Treasury Department Regulations to Eliminate or Reduce the Taxation of Debt Forgiven under the IBR or PAYE Plans

John Brooks, in a recent Tax Notes article, has argued that the Treasury Department may well have authority under the Code to administratively exclude forgiven student loan debt from taxable income under these Plans. ${ }^{267}$ Brooks offers several alternative bases for such exclusion that a later Administration might pursue if it is so inclined. ${ }^{268}$

First, Brooks argues that the amount of student loan debt forgiven by the IRS under one or another of the Plans could be credibly deemed by Treasury Department regulation to be a "qualified scholarship" that is excluded from inclusion in income under Code section 117. ${ }^{269}$ Second, he argues that the rather vague and ambiguous insolvency provision of Code section 108(a)(1)(B) could be administratively defined by the Treasury Department to clearly exclude a broad range of assets in determining taxpayer insolvency, thereby making that insolvency exclusion available to a much broader group of Plan enrollees, although not all of them. ${ }^{270}$ Third, he argues that the forgiven debt under these Plans can be reasonably regarded as merely being a contingent liability for which the contingency condition did not occur, rather than as discharged debt that would be subject to taxation. ${ }^{271}$ Finally, he offers an interesting argument that the borrower's original enrollment in one or another of the Plans after his or her graduation constitutes a "significant debt modification." While such a modification would normally call for immediate inclusion of any debt that is thereby forgiven in income under Code section 108(e)(10), Brooks notes that in this instance there is a practical inability to value the new Plan debt instrument, since the payments are contingent on future income, as well as a practical inability to value the old debt instrument because of the continual availability to the obligee of changing to the IBR option. ${ }^{272}$ In his view, in light of these severe valuation difficulties, the IRS should simply ignore the modification transaction for tax purposes. ${ }^{273}$

years after adoption and therefore, would not be required to be subjected to the Congressional Budget Office scoring process that would make such a proposal more politically visible and probably also more controversial.

267. See Brooks, supra note 67, at 751-52.

268. Id. at $751-57$.

269. Id. at $754-55$.

270. Id. at $755-56$.

271. Id. at 756 .

272. Id. at $756-57$.

273. Id. at 757 . 
The advantage to an Administration of pursuing one or more of these regulatory approaches, rather than pressing for legislation to amend the Code, is of course that Congressional approval would not be required. Brooks does recognize that each of these regulatory approaches is subject to an at least somewhat plausible rejoinder that the Treasury Department would be misconstruing the relevant statutes, or exceeding the scope of its delegated authority, or both. ${ }^{274}$ Nevertheless, one or more of these regulatory approaches could be pursued by a subsequent Administration that wanted to minimize or eliminate the tax bomb, but felt that was politically constrained from doing so in a more straightforward legislative manner by a resistant Congress.

Let me now turn to several more modest legislative or administrative measures that may also be promising options to pursue for those who favor reducing the magnitude of the tax bomb. ${ }^{275}$

\section{Amendment of the Internal Revenue Code to Allow Taxes Imposed on Forgiven Student Loan Debt to be Paid Over a Several-Year Period}

As I have discussed, there will probably be debt forgiveness tax obligations imposed on many PAYE Plan graduate enrollees of $\$ 50,000$ to $\$ 100,000$, or even larger amounts, from 2033 onwards. Since these taxes will be imposed on imputed income that is not actually received, those enrollees who at that time have limited assets, or whose assets are not in liquid form, may have difficulty coming up with sufficient funds to pay those taxes in the year of debt forgiveness. If they are instead permitted to pay these debt forgiveness taxes over a several-year period, perhaps over as much as five years, and can do so subject to at most a nominal interest rate sufficient to offset the Treasury's borrowing costs on the deferred tax payments, this will alleviate the problems of many if not most of those law graduate enrollees whose difficulties are primarily of a cash flow nature rather than relative poverty without adversely impacting the public fisc. ${ }^{276} \mathrm{I}$

274. Id. at $754-56$.

275. Field, supra note 212.

276. For example, suppose that the Code was changed to allow Plan enrollees to pay their debt forgiveness tax liability over five years of equal-size payments, but with a $3 \%$ annual interest rate also imposed on the deferred payments. Consider the circumstances of an average 2014 Paye Plan enrollee with a $\$ 70,000$ debt forgiveness tax liability imposed in 2034 on $\$ 210,000$ of forgiven debt. In 2033 , that enrollee would owe taxes of $\$ 70,000 / 5=\$ 14,000$. In 2035 , they would owe $\$ 14,000 \times 1.03=\$ 14,420$. In 2036 , they would owe taxes of $\$ 14,000$ $x(1.03)^{2}=\$ 14,853$. In 2037 , they would owe taxes of $\$ 14,000 \times(1.03)^{3}=\$ 15,298$. And in 
favor adoption of such a Code amendment along these general lines to allow deferred tax payments, and I believe that this is the only change in the law that should be made. ${ }^{277}$

\section{Legislative Restriction of the Amount of Loan Debt that can be Repaid under the IBR or PAYE Plans}

A fourth possible measure, in this case a prospective measure that would impact only future Plan enrollees and not current enrollees, would be to legislatively limit the amount of debt that can be repaid through these Plans, perhaps limited to the maximum amount of federal loans that can be taken out by a financially independent person for the purpose of financing undergraduate studies, currently $\$ 57,500 .{ }^{278}$ With this restrictive limit on the amount of enrollee debt that can be covered by the IBR and PAYE Plans, future law graduates enrollees would rarely if ever have any remaining unpaid debt after twenty-five years of making the required repayments on such a modest amount of debt, so they would not bear any significant debt forgiveness tax liability.

While this proposed prospective measure would essentially eliminate the tax bomb for future Plan law graduate enrollees, it would not address the looming tax liability problem facing current Plan law graduate enrollees and some other current Plan enrollees with large loan debts. It would leave in place the $\$ 50,000$ to $\$ 100,000$ or more individual tax obligations that will be coming due for many existing PAYE Plan law graduate enrollees, and the large aggregate tax obligations that will be imposed on Plan enrollees in 2033 and for years after that. It therefore would fail to mitigate the most pressing aspect of the tax bomb problem, if that is what one seeks to achieve.

Moreover, this legislative measure could easily have the unfortunate and unintended collateral consequence of putting a large number of law schools out of business in relatively short order. As I have discussed in some detail in my earlier article, law school enrollments have significantly declined in recent years as the job prospects for young lawyers have deteriorated, and

2038 , they would make their final tax payment of $\$ 14,000 \times(1.03)^{4}=\$ 15,757$. Such a payment schedule would surely help to address enrollee cash flow and liquidity concerns.

277. See also Laplante, supra note 211, at 724-31 (discussing the merits of a somewhat similar proposal to provide student loan borrowers with an extended period to pay debt forgiveness taxes).

278. 34 C.F.R. $\S 685.203(\mathrm{e})(2)(2016)$. 
many law schools are presently under considerable financial stress. ${ }^{279}$ Legal education is now an industry plagued by substantial overcapacity, with all that this implies for individual providers. ${ }^{280}$ Moreover, most law schools below the handful of schools at the most elite level have become increasingly dependent upon the ability of their students to finance the high tuitions charged with federal student loans that can be repaid under generous Plan terms. ${ }^{281}$ A $\$ 57,500$ cap on the amount of loan debt that can be repaid under the Plans would reduce the number of persons willing to attend in law school, perhaps dramatically so, threatening the survival of many lower- and mid-tier law schools. ${ }^{282}$

There is clearly is pronounced overcapacity in legal education, relative to the number of well-paid attorney positions that are currently available to new law graduates that justify incurring the costs of a legal education. But the sudden reduction in the number of law schools that would probably result fairly quickly from the effective denial of Plan enrollment to high-debt law graduates, even were this de facto ineligibility to be phased in over a several-year period, is probably not the best way to achieve the needed adjustment in legal education to the difficult current labor market conditions for new attorneys. Primarily for this reason, I do not favor the adoption of such a restriction on Plan eligibility.

\section{Restoration of the Original IBR Requirement of Monthly Repayments of $15 \%$ of Discretionary Income}

As one final proposal for the reader's consideration, I would suggest simply prospectively imposing for future enrollees in any of the Plans the $15 \%$ of discretionary income minimum monthly repayment requirement that existed when the IBR program was originally adopted in $2007 .^{283}$ That measure would increase the monthly repayment requirements for all future new IBR Plan and PAYE Plan and REPAYE Plan enrollees by $50 \%{ }^{284}$ With these larger required repayments, the amount of debt forgiven and tax liability imposed on these Plan enrollees would be significantly reduced.

279. See generally Crespi (2014), supra note 32 (discussing the serious financial crisis facing legal education following decades of increases in the real costs of attending law school).

280. Id.

281. Id.

282. Id. at $139-40$.

283. College Lost Deduction and Access Act of 2007, Pub. L. No. 110-84, § 203(a), 121 Stat. 784,792 .

284. $15 \% / 10 \%=1.5$, a $50 \%$ increase. 
For example, the hypothetical "average" 2014 PAYE Plan enrollee with a $\$ 160,000$ initial debt load, whose circumstances I have extensively considered, would now have an initial payment obligation of $\$ 497$ per month rather than $\$ 332$ per month, ${ }^{285}$ and under my 5\% annual salary growth assumptions, would now have to make monthly repayments over the twenty-year repayment period averaging approximately $\$ 876$ per month rather than $\$ 585$ per month. ${ }^{286}$ Those $50 \%$ larger monthly repayments over the twenty-year repayment period would enable that PAYE Plan enrollee to reduce their outstanding debt balance at the time of debt forgiveness to about $\$ 155,000$, rather than $\$ 211,000$, as I have earlier calculated, ${ }^{287}$ thereby reducing their tax liability by about $27 \%$ from about $\$ 70,000$ to about $\$ 52,000 .^{288}$

This proposed prospective $50 \%$ increase in the size of the required repayments could not, however, be imposed on existing new IBR Plan or PAYE Plan or (some) REPAYE Plan enrollees who have a contractual right under their Plans to only make repayments of $10 \%$ of their discretionary income. It would therefore, unfortunately, not have any impact upon the looming large $\$ 50,000$ to $\$ 100,000$ or more tax bomb obligations that will come due for many current PAYE Plan law graduate enrollees in 2033 and afterwards.

\section{CONCLUSION}

There is a tax bomb primed to go off in 2033 which will each year impose increasingly large cancellation of indebtedness-based federal and state income tax liabilities, reaching one billion dollars per year or more by 2039 , on tens of thousands of mid-career lawyers who have previously incurred large federal student loan debts, who have subsequently enrolled in the IBR or PAYE Plans, and who unfortunately have been able to earn only relatively modest annual incomes (as compared to average lawyer salaries) in the twenty or twenty-five years following their law school graduation. As I have demonstrated as best I can given the very limited information available, these tax bills will often be in the neighborhood of $\$ 50,000$ to

285. $\$ 332$ per month $\times 1.5=\$ 497$ per month. month.

286. $\$ 497$ per month $x(1.065)^{9}=\$ 876$ per month. $\$ 332$ per month $\times(1.065)^{9}=\$ 585$ per

287. See supra note 154 (presenting amortization results for an old IBR Plan enrollee starting with an initial debt of $\$ 160,000$ and $\$ 497$ monthly payments).

288. $\$ 211,000 \times .333=\$ 70,263 . \quad \$ 155,000 \times .333=\$ 51,615 . \quad(\$ 70,263-$ $\$ 51,615) / \$ 70,263=0.265$, a $26.5 \%$ reduction in tax liability. 
$\$ 100,000$ or more for PAYE Plan law graduate enrollees, and $\$ 15,000$ to $\$ 25,000$ for old IBR Plan law graduate enrollees.

These tax obligations will be imposed on income that is attributed to, but not actually received by, these taxpayers, which will create problems. Many of these lawyers will likely have failed to adequately provide for this large tax obligation, and will find that it will impair or even devastate their retirement plans. In addition, each year, a larger group of perhaps tens of thousands of people who have incurred loan debts of up to $\$ 50,000$ or more to finance medical school or Ph.D. work or other non-legal graduate studies, or undergraduate coursework, and who over the following two decades have also unfortunately been able to earn only relatively modest incomes, will also, under these Plans, face cancellation of indebtedness-based income tax bills that could, in some cases, be fairly substantial, although generally not of the same order of magnitude as the tax liabilities facing lawyers.

Whether some legislative or administrative actions should be taken before 2033 to mitigate or even eliminate this tax bomb is a difficult question upon which reasonable people can differ. I have concluded that no action should be taken except for a minor amendment to the Internal Revenue Code that would allow persons subject to debt forgiveness tax obligations based on discharged student loan debt to pay those taxes over several years, rather than having to pay it all in the year in which the debt is forgiven, without undue penalty. However, since some people believe that further mitigation efforts are called for, I have suggested and discussed several possible alternative measures that could be pursued, ranging from a legislative amendment to the Internal Revenue Code that would eliminate altogether any debt forgiveness tax liability for Plan enrollees down to some more modest legislative or administrative measures that would have more limited and/or only prospective tax liability-reducing effects for future Plan enrollees. I hope by this Article to contribute to a more informed discussion of this question prior to the first tax bomb obligations that will be coming due in 2033. 
7. Complete Aaling Address of Known Offee of Publication (Not pmiter) (Street, chly, county state, and ZlP +4 ) South Carolina Law Review

Universty of South Caroina school of taw

701 Mant street

Columtia $5 \mathrm{C} 2920$

8. Complete Maing Address of Headquaters or General Eusiness office of Publisher Not pinter

9. Full Names and Complete Malling Addresses of Fublisher, Editor, and Managing Editor foo rol leave blank

Publisher (Name and complete mailing address)

South Carolna Law Review

Wriversity of South Carotina school of Law

701 Main Street, Coinntiat SC 20208

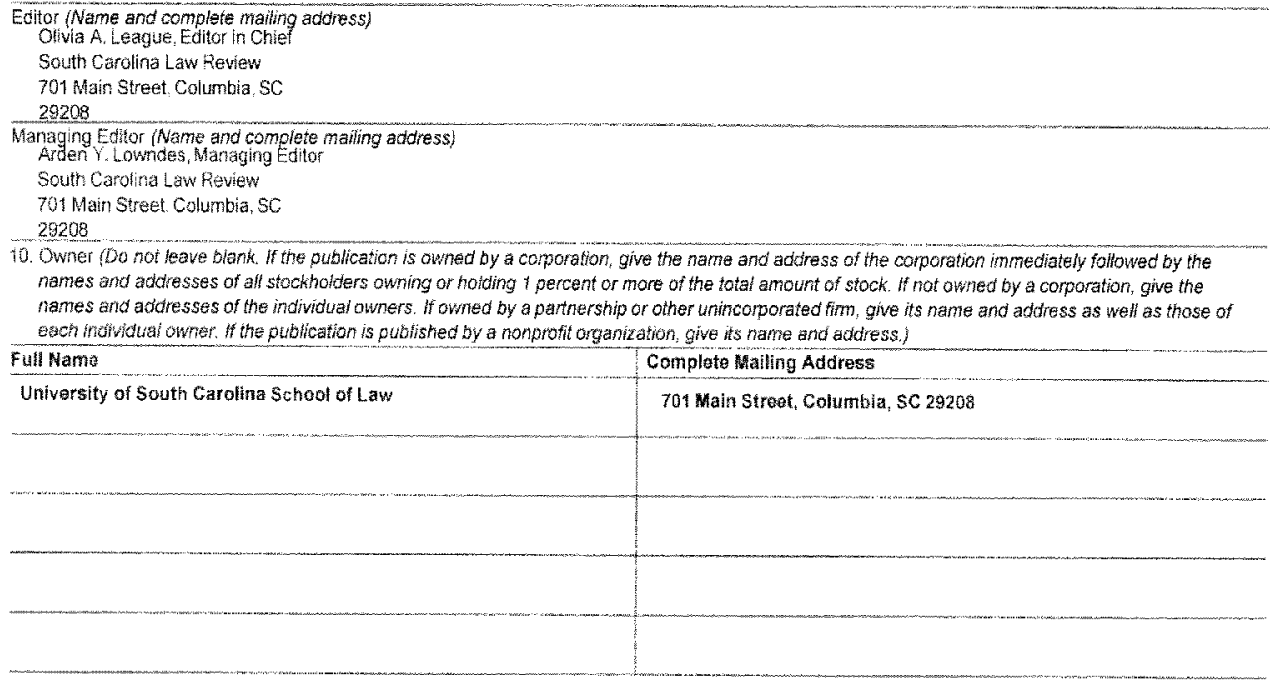

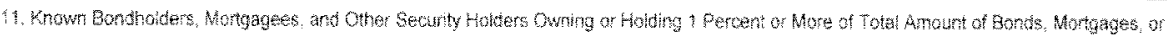

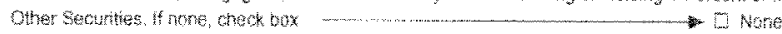

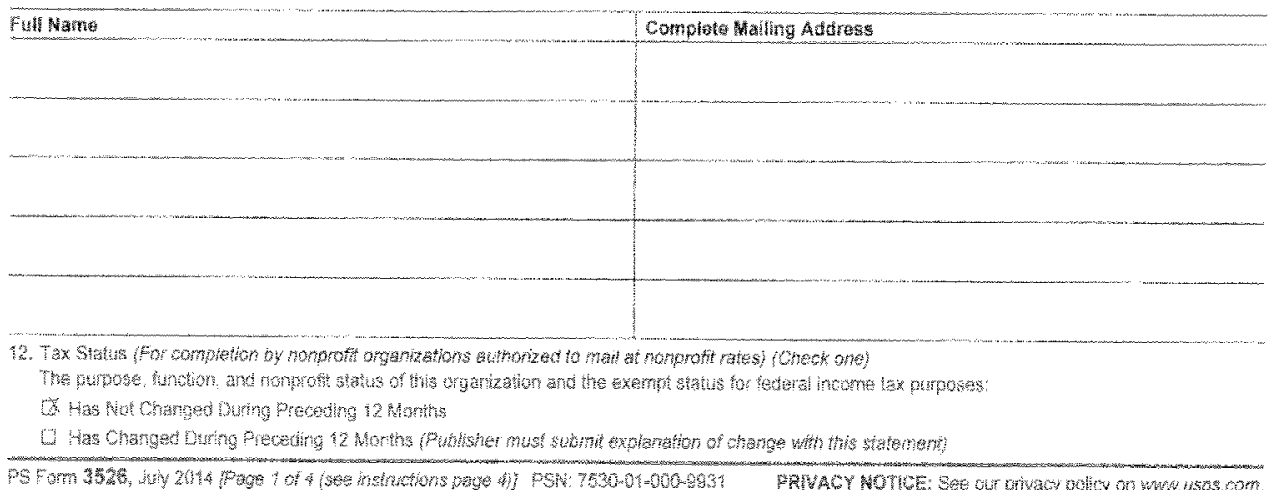




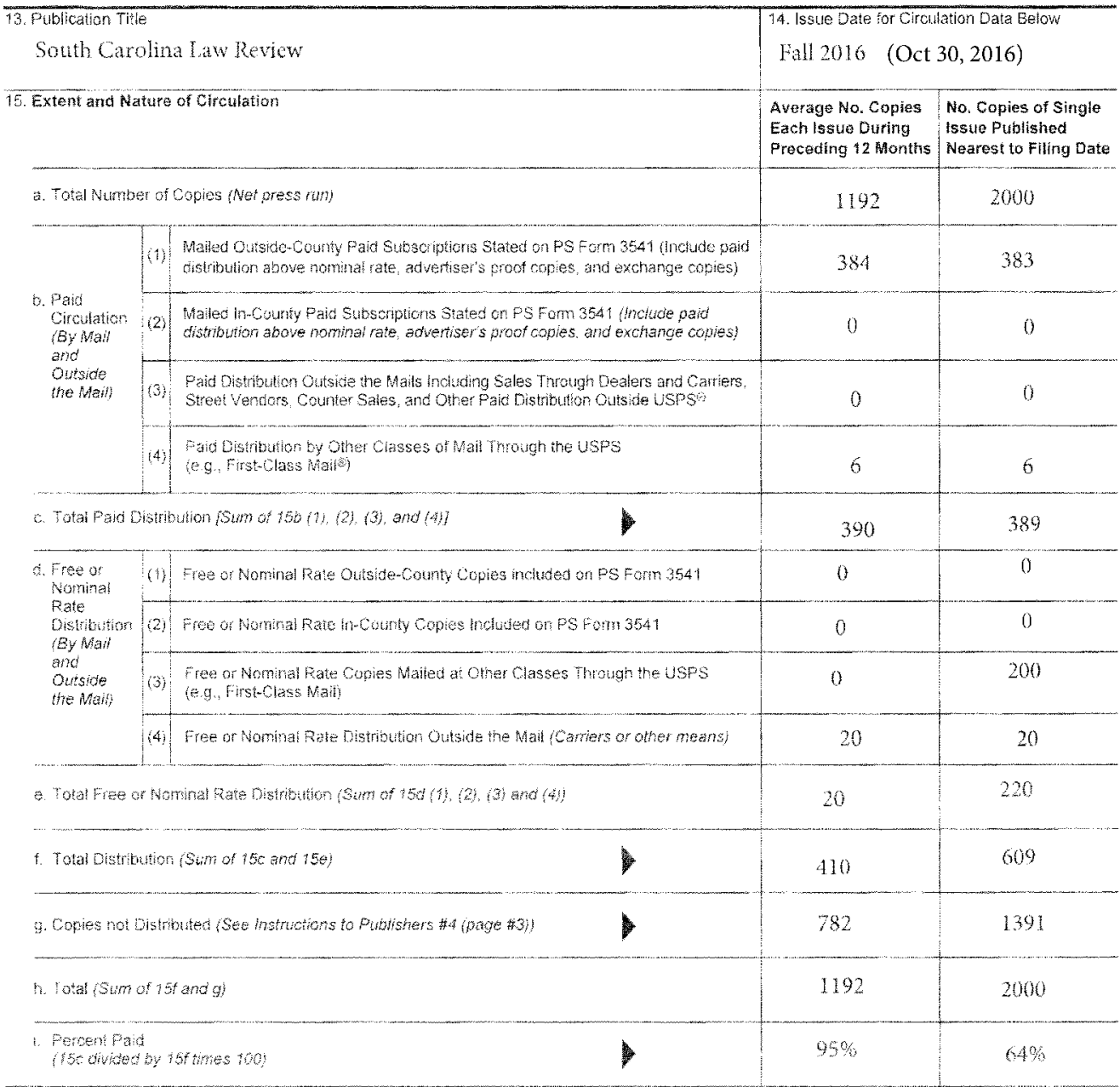

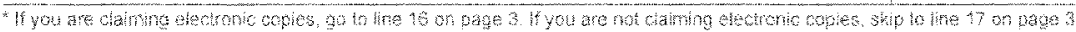




\begin{tabular}{|c|c|c|}
\hline 16. Electronic Copy Circulation & $\begin{array}{l}\text { Average No. Copies } \\
\text { Each issue During } \\
\text { Preceding } 12 \text { Months }\end{array}$ & $\begin{array}{l}\text { No. Copies of Single } \\
\text { Iss ue Published } \\
\text { Nearest to Filing Date }\end{array}$ \\
\hline a. Paid Electronic Copies & 1 & 1 \\
\hline b. Total Paid Print Copies (Line $15 \mathrm{c}$ ) + Paid Electronic Copies (Line 16a) & 391 & 300 \\
\hline c. Total Print Distribution (Line 15f) + Paid Electronic Copies (Line 16a) & 411 & 610 \\
\hline d. Percent Paid (Both Print \& Electronic Copies) (16b divided by $16 \mathrm{c} \times 100$ ) & $95 \%$ & $64 \%$ \\
\hline
\end{tabular}

X certify that $50 \%$ of all my distributed copies (electronic and print) are paid above a nominal price.

17. Publication of Statement of Ownership

$X$ If the pubication is a general publication, publication of this statement is required. Will be printed

Pubfication not required in the October 30, 2016 issue of this
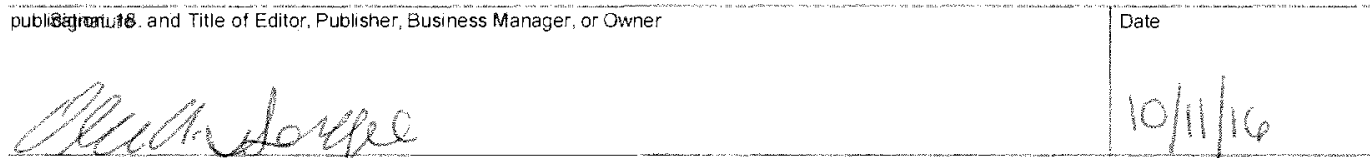

I certify that all information furnished on this form is true and complete. I understand that anyone who furtisnes false or misleading information on this form or who omits material or information requested on the form may be subject to criminal sanctions (including fines and imprisonment) and/or civil sanctions (including civil penalties). 


\section{ORDER THROUGH HEIN!}

Get your missing back volumes and issues through Hein!

We have obtained the entire back stock, electronic, reprint and microform rights to ...

\section{South Carolina Law Review}

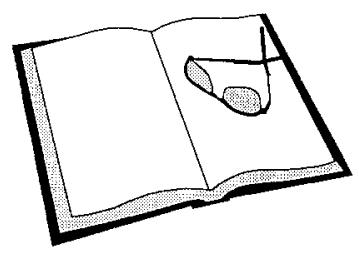

Complete sets to date are available now! We can also furnish single volumes and issues!

\section{BACK ISSUES ALSO AVAILABLE IN HEIN-ON-LINE! \\ http://heinonline.org}

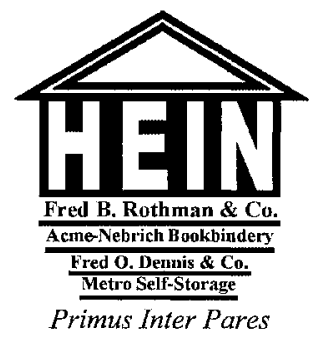

WILLIAM S. HEIN \& CO., INC.

Law Publisher / Serial \& Subscription Agent / Micropublisher New \& Used Law Books / Preservation Printer / Bookbinder 1285 Main Street, Buffalo, New York 14209

(716) 882-2600 - TOLL FREE (800) 828-7571 - Fax (716) 883-8100

E- Mail mail@wshein.com - Web Site www.wshein.com 


\section{SOUTH CAROLINA \\ LAW REVIEW}

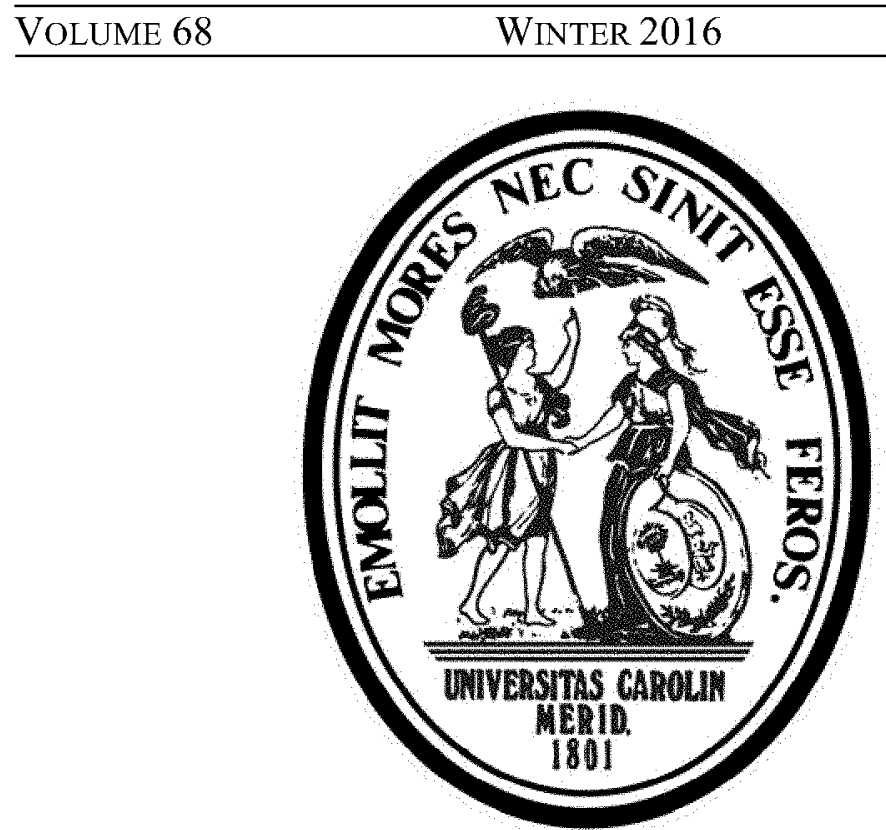

Except as otherwise expressly provided, the author of each article in this volume has granted permission for copies of that article to be made for any educational use, provided that (1) copies are distributed at or below cost; (2) the author and South Carolina Law Review are identified; and (3) notice of the use is given to South Carolina Law Review.

\section{(C) Copyright 2016 by the South Carolina Law Review}

Member of the National Conference of Law Reviews and the Peer Reviewed Scholarship Marketplace.

The South Carolina Law Review (ISSN 0038-3104) is published quarterly by the University of South Carolina School of Law, Columbia, SC 29208. Subscription rate: $\$ 40.00$ per year payable in advance, $\$ 35.00$ per year for members of the South Carolina Bar. Periodical postage paid at Columbia, SC, and additional mailing offices.

POSTMASTER: Please send address changes to South Carolina Law Review, University of South Carolina School of Law, 701 Main St., Columbia, SC 29208.

The Law Review seeks to publish materials representing meritorious viewpoints on subjects of interest to the legal profession. Publication does not indicate that the views expressed are adopted by the Law Review. The Law Review accepts submissions by mail or email sent to submissions@sclawreview.org. Manuscripts received by mail are not returned unless accompanied by a stamped, self-addressed envelope.

All citations conform to The Bluebook: A Uniform System of Citation (Columbia Law Review Ass'n et al. eds., 20th ed. 2015). South Carolina cases are cited to South Carolina Reports in conformity with South Carolina Appellate Court Rules. 


\section{SOUTH CAROLINA \\ LAW REVIEW}

\begin{tabular}{lll}
\hline VOLUME 68 & 2016-2017 & NuMBERS 1-4 \\
\hline
\end{tabular}

\section{BOARD OF EDITORS}

Olivia A. League

Editor in Chief

CARoline A. Ross

Executive Student Works Editor

MEGAN ClEMENCY

Senior Student Works Editor

Katie ELIZABETH LOWERY

ALICIA E. MORRIS

MiCHAEL RABB

Student Works Editors

ALEIA HORNSBY

Senior Research Editor

BRANDON J. GREGG

Charlotte Harrell

WHITNEY KAMERZEL

Research Editors

KATHERINE ABDULLAH

HAMILTON BARBER

HOLLY BROWN

Sarah Tate Chambers

ETHAN B. CLARK

ELLIOT CONDON

ZACHARY J. CROWL

Kayla Marie AdRIANNa Culver

ANTHONY D'ELIA

Ross DURANT

LISA A. EICHHORN
KAITLIN BECK

EMILY RUMMEL

DEREK TARVER

Claire Voegele

LIZZIE WESTON

KATHLEEN M. BuRE

Executive Articles Editor

VICTORIA HARVEY

REED MULBRY

Senior Articles Editors

\section{BRIAN CRITZER}

SAM EHRLICH

ELLIOT LONCAR

HILARY MARTIN

Articles Editors

RYAN JONES

Peer Review Editor

\section{Editorial StafF}

Chelsea N. Evans

JAMES DAVID GEORGE, JR. JENNIFER GREENE

MATTHEW HARRISON

EUGENE GORDON HAY, VI

ELLE KLEIN

JOHN DUNBAR KORNGAY, III

TYRA S. MCBRIDE

Creasie M. Parrott

J. EVAN PHILLIPS

Martin C. MCWiLliams, JR.

PHILIP T. LACY

Faculty Advisors

KIM L. FANNING

Administrative Assistant
Associate Editors in Chief
ARDEN Y. LOWNDES

Managing Editor

SETH JOHNSON

Associate Managing Editor

Clarke W. MCCants, IV

Technology Editor

CATE CaRdinale

Fourth Circuit Editor

HALEy R. BASTIAN

ABIGAIL A. CARSON

Symposium Editors

RAYMOND J. PRINCE

MATTHEW ROBINS

CHANDLER DAVID Rowh

RONALD T. SCOTT

JOSEPH D. SPATE

JACOB TAYLOR

JONATHAN TODD

SHANNON L. VOGAN

ELIZABETH K. VONKELLER

GRANT WILLS

HOWARD B. STRAVITZ 


\section{UNIVERSITY OF SOUTH CAROLINA SCHOOL OF LAW FACULTY 2016-2017}

\section{ADMinistration}

Robert M. Wilcox, A.B., J.D.; Dean and Professor of Law

Jaclyn A Cherry, B.A., J.D.; Associate Dean for Academic Affairs and Professor of Law Colin Miller, B.A., J.D.; Associate Dean of Faculty Development and Professor of Law Duncan E. Alford, B.A., J.D., M.L.I.S.; Associate Dean and Director of the Law Library, Professor of Law

Susan Palmer, B.A., J.D.; Associate Dean for Student Affairs

Karen Britton, Director of Admissions

Gary Moore, B.S.; Assistant Dean for Academic Technology

Elizabeth Niehaus, A.B., M.B.A.; Assistant Dean for Administration

\section{EMERITUS}

F. Ladson Boyle, B.S., J.D., LL.M.; Charles E. Simons, Jr. Professor Emeritus of Federal Law R. Randall Bridwell, B.A., J.D., LL.M.; Distinguished Professor Emeritus of Law

Katharine I. Butler, B.S., M.Ed., J.D.; Distinguished Professor Emeritus of Law

W. Lewis Burke, B.A., J.D.; Professor of Law and Director

Vance L. Cowden, B.A., J.D.; Distinguished Professor Emeritus of Law

Nathan M. Crystal, B.S., J.D., LL.M.; Distinguished Professor Emeritus of Law and Class of 1969 Professor Emeritus of Professional Responsibility and Contract Law

Richard E. Day, B.S., J.D.; Distinguished Professor Emeritus of Law

Robert L. Felix, A.B., LL.B., M.A., LL.M.; James P. Mozingo, III Professor Emeritus of Legal Research, Distinguished Professor Emeritus of Law

James F. Flanagan, A.B., LL.B.; Oliver Ellsworth Distinguished Professor Emeritus of Federal Practice

John P. Freeman, B.B.A., J.D., LL.M.; Distinguished Professor Emeritus of Law and John T. Campbell Distinguished Professor Emeritus of Business and Professional Ethics

Thomas R. Haggard, B.A., LL.B.; Distinguished Professor Emeritus of Law

F. Patrick Hubbard, B.A., J.D., LL.M.; Ronald L. Motley Distinguished Professor of Tort Law Herbert A. Johnson, A.B., M.A., Ph.D., LL.B.; Distinguished Professor Emeritus of Law

Henry S. Mather, B.A., M.A., J.D.; Distinguished Professor Emeritus of Law

William S. McAninch, B.A., LL.B., LL.M.; Distinguished Professor Emeritus of Law

Ralph C. McCullough, II, B.A., J.D.; Distinguished Professor Emeritus of Law

John E. Montgomery, B.Ch.E., J.D., LL.M.; Distinguished Professor Emeritus of Law, Dean Emeritus

Dennis R. Nolan, A.B., M.A., J.D.; Distinguished Professor Emeritus of Law and Webster Professor Emeritus of Labor Law

David G. Owen, B.S., J.D.; Carolina Distinguished Professor of Law

Burnele Venable Powell, B.A., J.D., LL.M.; Miles and Ann Loadholt Professor of Law

O'Neal Smalls, B.S., J.D., LL.M.; Distinguished Professor Emeritus of Law

Stephen A. Spitz, B.S., J.D.; Distinguished Professor Emeritus of Law

Roy T. Stuckey, B.A., J.D.; Distinguished Professor Emeritus of Law and Webster Professor Emeritus of Clinical Legal Education

Jon P. Thames, J.D., LL.M.; Distinguished Professor Emeritus of Law

James L. Underwood, A.B., J.D., LL.M.; Distinguished Professor Emeritus of Law

Eldon D. Wedlock, Jr., A.B., J.D., LL.M.; Distinguished Professor Emeritus of Law

\section{FACULTY}

Gregory B. Adams, B.S., J.D., LL.M., J.S.D.; Associate Professor of Law

Janice M. Baker, B.A., J.D.; Assistant Director of Legal Writing

Jay Bender, B.A., J.D.; Lecturer

Derek W. Black, B.A., J.D.; Professor of Law

Robert T. Bockman, B.A., M.A., J.D.; Senior Legal Writing Instructor

Marie C. Boyd, A.B., J.D.; Assistant Professor of Law

Josephine F. Brown, B.A., J.D.; Associate Professor of Law

James R. Burkhard, B.A., M.A., J.D.; Associate Professor of Law

Elizabeth Chambliss, B.S., M.S., Ph.D., J.D.; Professor of Law and Director, NMRS Center on Professionalism

Thomas P. Crocker, B.A., M.A., M.A., Ph.D., J.D.; Professor of Law

Elizabeth M. Dalzell, B.S., J.D.; Legal Writing Instructor

Tessa Davis, B.S., J.D., LL.M.; Assistant Professor of Law

Joshua G. Eagle, B.A., M.S., J.D.; Professor of Law

Lisa A. Eichhorn, A.B., J.D.; Director of Legal Writing \& Professor of Law

Ann M. Eisenberg, J.D., LL.M.; Assistant Professor of Law

Patrick J. Flynn, A.B., J.D.; Associate Professor of Law

Jacqueline R. Fox, B.A., J.D.; LL.M.; Associate Professor of Law 
Kenneth W. Gaines, B.S., J.D., LL.M.; Associate Professor of Law

Joshua Gupta-Kagan, B.A., J.D.; Assistant Professor of Law

Susan S. Kuo, A.B., J.D.; Professor of Law

Philip T. Lacy, B.A., LL.B.; Professor of Law

Shelby Leonardi, B.A., J.D.; Legal Writing Instructor

Ami Leventis, B.A., J.D.; Legal Writing Instructor

David K. Linnan, B.A., J.D.; Associate Professor of Law

Martin C. McWilliams, Jr., B.A., J.D., LL.M.; Professor of Law

Benjamin Means, A.B., J.D.; Associate Professor of Law

S. Alan Medlin, B.A., J.D.; David W. Robinson Professor of Law; Associate Professor of Law

Amy L. Milligan, B.S., B.A.; J.D.; Assistant Director of Legal Writing

Eboni S. Nelson, B.A., J.D.; Professor of Law

Elizabeth G. Patterson, B.A., J.D.; Professor of Law

Aparna Polavarapu, B.S., J.D., M.A.L.D.; Assistant Professor of Law

Walter F. Pratt, Jr., B.A., D.Phil., J.D.; Professor of Law

Claire Raj, B.A., J.D.; Assistant Professor of Law

Nathan Richardson, B.S., J.D.; Assistant Professor of Law

Wadie E. Said, A.B., J.D.; Associate Professor of Law

Joel H. Samuels, A.B., M.A., J.D.; Professor of Law

Joseph A. Seiner, B.B.A., J.D.; Professor of Law

Bryant Walker Smith, B.S., J.D., LL.M.; Assistant Professor of Law

Ned Snow, B.A., J.D; Associate Professor of Law

Seth Stoughton, B.A., J.D.; Assistant Professor of Law

Howard B. Stravitz, B.A., J.D.; Associate Professor of Law

Emily F. Suski, B.A., J.D., M.S.W., LL.M.; Assistant Professor of Law

Michael J. Virzi, B.A., J.D.; Legal Writing Instructor

Anne Marie Ugarte, B.A., J.D.; Assistant Professor of Law, Department of Clinical Legal Studies

Shelley Welton, B.A., J.D., M.P.A., Ph.D.; Assistant Professor of Law

Marcia A. Yablon-Zug, A.B., J.D.; Associate Professor of Law

\section{COLEMAN KARESH LAW LIBRARY FACULTY}

Duncan E. Alford, B.A., J.D., M.L.I.S.; Associate Dean and Director of the Law Library, Professor of Law

Terrye M. Conroy, B.S., J.D., M.L.I.S.; Assistant Director of Legal Research Instruction Aaron Glenn, B.A., J.D., M.L.I.S.; Reference Librarian

Rebekah K. Maxwell, B.A. J.D., M.L.I.S.; Associate Director for Library Operations

Pamela Rogers Melton, B.A., J.D., M.S.L.S.; Associate Director for Library Administration

Cornelius Pereira, B.A., M.A., M.L.I.S.; Head of Technical Services

Eve Ross, B.A., M.L.I.S.; Reference Librarian

Candle M. Wester, B.S., J.D., M.S.L.I.S.; Assistant Director for Faculty Services

\section{AdjunCt And Visiting Faculty}

\footnotetext{
Hon. Joseph F. Anderson, Jr.

Hon. James R. Barber, III

Brett H. Bayne

Edward H. Bender

Shannon Bobertz

William B. Brannon

Robert H. Brunson Justin Byars

Ronald M. Childress Joseph D. Clark

Lesley M. Coggiola Thomas Cooper

C. Jennalyn Dalrymple Patrick G. Dennis David Duncan Hon. John C. Few

Hon. John D. Geathers

Christopher Todd Hagins
}

Richard Handel

Richard Harpootlian Rachel Hedley Hon. Shiva V. Hodges

Christopher G. Isgett

Lee P. Jedziniak

Don Kempf

Bill Killough

Stanford E. Lacy

John K. Langford

Regina Hollins Lew is

Ernest Lipscomb

Randolph R. Lowell

James B. Lybrand, Jr.

Cory E. Manning

Joseph M. McCulloch, Jr.

Lawrence C. Melton
Franchelle C. Millender E. Scott Moise

Sarah M. Montgomery

Deborah Morgan

Clarke Newton

Hon. Charles F. Reid

Hon. Dennis W. Shedd

Teri Stomski

Karen Thomas

Justin Richard Werner

Travis C. Wheeler

Hon. H. Bruce Williams

Nanette Swalm Williams

Benton D. Williamson

Richard Willis

Isvara Wilson

William K. Witherspoon

David S. Wyatt 